\title{
GERENCIAMENTO VISUAL DA PRODUÇÃO E TRABALHO EM GRUPOS: FERRAMENTAS DO SISTEMA JUST IN TIME APLICADAS SIMULTANEAMENTE EM UMA INDÚSTRIA DE CALÇADOS
}

\section{Lincoln Morikoshi Ciosaki}

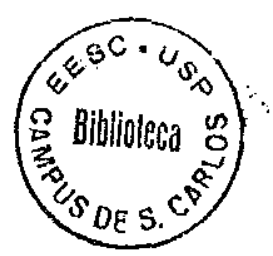

Dissertação apresentada à Escola de Engenharia de São Carlos da Universidade de São Paulo, como parte dos requisitos para obtenção do título de Mestre em Engenharia de Produção.

ORIENTADOR: Prof. Dr. Alfredo Colenci Jr

São Carlos

dezembro de 1999 


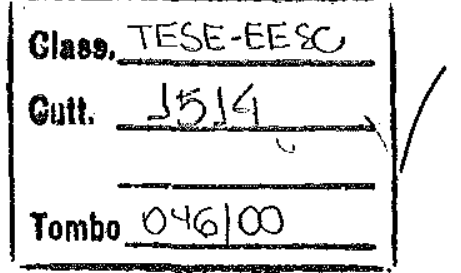

$51 / 51070645$

Ficha catalográfica preparada pela Seção de Tratamento da Infommação do Serviço de Blblloteca - EESC/USP

Ciosaki, Lincoln Morikoshi.

Gerenciamento visual da produção e trabalho em grupos : ferramentas do sistema just in time aplicadas simultaneamante em uma indústria de calçados / Lincoln Morikoshi. Ciosaki. -- São Carłos, 1999.

Dissertação (Mestrado) -- Escola de Engenharia de São Carlos-Universidade de são Paulo, 1999.

Área: Engenharia de produção.

orientador: Prof. Dr. Alfredo Colenci Jr.

1. Just in time. 2. Gerenciamento visual da produção. 3. Trabalho em grupos. 4. Indústria de calçados. I. Título. 


\section{Dedicatória}

Minha esposa Elaine e meus filhos Vitor e Laís. Obrigado pelo tempo concedido pacientemente para que esta dissertação se transformasse em realidade. Vocês sâo motivos para uma existência feliz e agraciada.

Meus pais Jin e Maria pela forma amorosa e consistente de construção ao longo dos anos.

Jesus Cristo, razão fundamental de viver ! Mais que retórica, o Deus vivo que está presente trazendo real sentido à toda existência. 
Agradecimentos

Ao Prof. Dr Alfredo Colenci Jr pela confiança demonstrada e orientação respeitosa no desenvolvimento da dissertação. Seu histórico acadêmico, determinação e idealismo pela VIDA é um exemplo a ser seguido.

A área de Engenharia de Produção dạ Escola de Engenharia de São Carlos Universidade de São Paulo - , professores e funcionários, pela forma sempre respeitosa e fértil de convívio e interação acadêmica, proporcionando grande incentivo intelectual e humano.

Aos colegas do Centro Universitário Moura Lacerda de Ribeirão Preto, pelo apoio e estímulo.

Aos colegas da indústria, apaixonados pela mesma sina. Aos operários de chão de fábrica, pelas experiências enriquecedoras e firmeza como enfrentam a vida. 


\section{SUMÁRIO}

LISTA DE FIGURAS vii

LISTA DE TABELAS viii

LISTA DE ABREVIATURAS E SIGLAS ix

RESUMO $\mathrm{X}$

ABSTRACT

1- INTRODUÇÃO 01

1.1- A organização dos capítulos $\quad 01$

2- O AMBIENTE INDUSTRIAL · 04

2.1 - Antiguidade e Idade Média 04

2.2- Renascimento 06

2.3- A expansão industrial 08

2.4- A administração científica 09

2.5- O período entre e pós guerra mundial 11

2.6- A década de 70 até os nossos dias 13

3- O SURGIMENTO DO SISTEMA JUST IN TIME 16

3.1- Fundamentação histórica e cultural do Japão 16

3.2- O ambiente que proporcionou o crescimento pós guerra 18 
3.3- A Toyota Motors Co 20

3.4- O termo Just In Time 23

4- ELEMENTOS DO SISTEMA JUST IN TIME 26

4.1- Introdução 26

4.2- Eliminação do desperdício -- 27

4.2.1- Desperdício de super produção 28

4.2.2- Desperdício de tempo disponivel 29

4.2.3-Desperdício em transporte 29

4.2.4-Desperdicio de processamento em sí 30

4.2.5-Desperdício de estoque disponível 31

4.2.6-Desperdício de movimentos 32

4.2.7- Desperdício de produzir produtos defeituosos $\quad 32$

4.3- Processo de melhorias contínuas 33

4.4- A gestão de recursos humanos - 35

4.5- O nivelamento da produção 37

4.6- A redução dos tempos de set $u p$

4.7- Operador multifuncional 41

4.8- Controle da Qualidade Total 44

4.9- Lay Out apropriados $\quad 46$

4.10- Sincronização da produção $\quad 49$

4.10.1- Sincronização externa 49

4.10.2- Sincronização interna 51

4.11- A inversão do fluxo de produção 52

5- GERENCIAMENTO VISUAL DA PRODUÇÃO 55

5.1- A administração da produção $\quad 55$

5.2- O fluxo de informações e o fluxo de materiais 56

5.3- Utilização de recursos computacionais para o controle de fluxo61 
5.4- O Gerenciamento visual da produção

5.4.1- O sistema Kanban 65

5.4.2-Andon $\quad 69$

5.4.3-'Quadros de situação pessoal 72

$\begin{array}{ll}\text { 5.4.4- Cartas de processo } & 73\end{array}$

6- TRABALHO EM GRUPOS 76

6.1- O trabalho em grupos na administração científica 76

6.2- O sistema sócio técnico 78

6.2.1- A fábrica da Volvo em Udevalla 80

6.3- O trabalho em grupo no sistema JIT $\quad 82$

6.3.1. Os círculos de controle de qualidade 85

6.3.2- Grupos na produção e participação do operário 86

7- O ESTUDO DE CASOS 90

7.1- A proposta 90

7.2- Elaboração do diagnóstico 91

7.3- O sistema de informações 92

7.3.1- Vendas 93

7.3.2- Planejamento \& controle da produção 93

7.3.3-Materiais 95

7.3.4- Compras 95

7.4- O Chão de fábrica 96

7.4.1- O sistema tarefeiro 96

$\begin{array}{ll}\text { 7.4.2- Corte } & 97\end{array}$

7.4.3- Preparação 98

7.4.4- Pesponto 99 
7.4.5- Esteira de montagem e acabamento

7.5- Estoque em processo

7.5.1- Inventário entre processos

7.5.2- Lead time de produção

102

7.6- Principais conclusões

103

8-MEDIDAS DE RACIONALIZAÇÕES

8.1- Metas de redução de inventários

105

8.2- $\mathrm{O}$ sistema de informações

106

8.3- O chão de fábrica

107

8.4- Organização de grupos de trabalho

108

8.4.1- Corte

109

8.4.2- Preparação

110

8.4.3- Pesponto

112

8.5- Gerenciamento visual da produção

114

8.6- Alterações no sistema tarefeiro

117

9-PROJETO PILOTO E IMPLANTAÇÃO

9.1- O projeto piloto na preparação .

119

9.2- O projeto piloto no pesponto

120

9.3- A implantação no pesponto

122

9.4- Implantação do gerenciamento visual da produção

125

10- CONCLUSÃO 


\section{LISTA DE FIGURAS}

Figura 4.1- Diferenciação entre operações e processos.......................................... 30

Figura 4.2- Diferenças entre o Kaizen e a Inovação ................................................ 34

Figura 4.3- Categorização dos empregados nas empresas brasileiras e japonesas ... 36

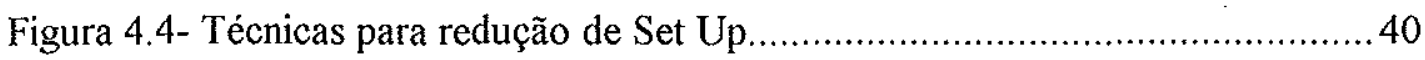

Figura 4.5- Flexibilidade de configuraçôes de linhas produção....................................48

Figura 5.1- Informações e hierarquizações do planejamento operacional na TMC .. 58

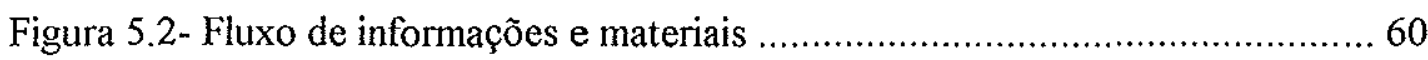

Figura 5.3- Sistema de Informações Gerenciais ..................................................... 61

Figura 5.4- Quadro luminoso de parada de linha .............................................. 70

Figura 6.1 - Principios de enriquecimento do trabalho ........................................ 84

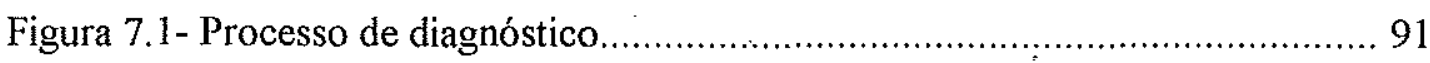

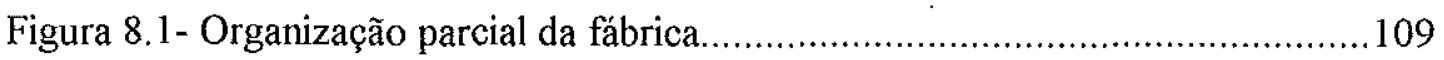

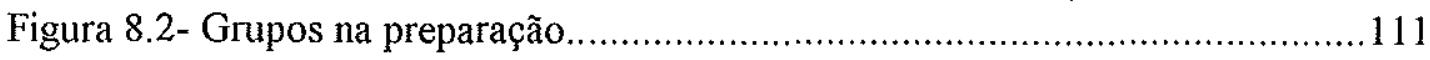

Figura 8.3- Quadros de gerenciamento visual da produção....................................115 


\section{LISTA DE TABELAS}

Tabela 7.1 - Inventários na fábrica...................................................... 102

Tabela 7.2- Lead Time de produção..................................................... 103

Tabela 8.1 - Sugestão de grupos de corte................................................... 110

Tabela 8.2- Sugestão de grupos na preparação.............................................112

Tabela 8.3- Sugestão de grupos no pesponto............................................. 113

Tabela 9.1 - Produtividade do grupo piloto de pesponto................................ 121

Tabela 9.2- Grupos de trabalho no pesponto A ......................................... 122

Tabela 9.3- Média de pares produzidos no pesponto A .....................................123

Tabela 9.4- Média de ganho semanal ( \%) no pesponto A .................................. 124

Tabela 9.5- Inventário nas seções pós gerenciamento visual.............................. 126 


\section{LISTA DE ABREVIATURAS E SIGLAS}

$\begin{array}{ll}\text { CCQ } & \text { Círculos de Controle de Qualidade } \\ \text { CIM } & \text { Computer Integraded Mamufacturing } \\ \text { JIS } & \text { Japan Industrial Standard } \\ \text { JIT } & \text { Just In Time } \\ \text { JUSE } & \text { Union of Japanese Scientists and Engineers } \\ \text { MITI } & \text { Ministry of International Trade and Industry } \\ \text { MRP I } & \text { Material Requirement Plaming } \\ \text { MRP II } & \text { Manufacturing Resources Planning } \\ \text { SAP } & \text { Sistemas de Administração da Produção } \\ \text { STP } & \text { Sistema Toyota de Produção } \\ \text { TQC } & \text { Total Quality Control } \\ \text { TMC } & \text { Toyota Motors Company } \\ \text { TRF } & \text { Troca Rápida de Ferramenta }\end{array}$




\section{RESUMO}

CIOSAKI, L. M. ( 1999 ). Gerenciamento visual da produção e trabalho em grupos: ferramentas do sistema just in time aplicados simultaneamente em uma indústria de calçados. São Carlos, 135 p. Dissertação ( Mestrado )- Escola de Engenharia de São Carlos, Universidade de São Paulo.

A indústria brasileira de calçados tem sido profundamente afetada pela pressão da competitividade global causada pela maior abertura do mercado. Ela possue caracteristicas peculiares de produção. Esta dissertação relata os resultados de incremento de produtividade em uma indústria de calçados orientados pelos principios da filosofia just in time, de forma especial através do gerenciamento visual da produção e do trabalho em grupos.

Palavras-chave: just in time; gerenciamento visual da produção; trabalho em grupos; indústria de calçados 


\section{ABSTRACT}

CIOSAKI, L. M. ( 1999 ). Gerenciamento visual da produção e trabalho em grupos: ferramentas do sistema just in time aplicados simultaneamente em uma indústria de calçados. São Carlos, 135 p. Dissertação (Mestrado )- Escola de Engenharia de São Carlos, Universidade de São Paulo.

The brazilian shoe industry has been deeply affect by the pressure of global competition caused by the opening of our market. It has very peculiar caractheristcs concerning the production. This dissertation relate the results to improve productivity in the shoe industry oriented by the principles of just in time philosophy, in a very particular way the implementing of visual management and work groups.

Keywords: just in time; production visual management; work groups; shoe industry 


\section{CAPÍTULO 1: INTRODUÇÃO}

O propósito deste capítulo é fornecer uma visão global da dissertação, suas ênfases principais, e registrar a forma como os conceitos são apresentados no decorrer do trabalho.

\section{1- A organização dos capítulos}

Muitos trabalhos tem sido publicados nos últimos 15 anos versando sobre a filosofia Just in time e as ferramentas associadas a esta nova forma de pensar o chão de fábrica. A contribuição que a presente dissertação procura proporcionar é um relato específico de como duas técnicas do sistema JT, o gerenciamento visual da produção e o trabalho em grupos, foram adaptadas e implantadas em uma indústria de calçados masculinos de couro.

O segundo capítulo apresenta um breve histórico que caracteriza o ambiente industrial e as principais ocorrências que contribuiram para a formação do atual quadro de desenvolvimento organizacional observado na indústria.

O sistema Just in time começa a ser abordado no terceiro capitulo. Na fundamentação teórica necessária ao assunto houve uma constante preocupação em fornecer uma visão um pouco mais relacional dos conceitos. Recorreu-se de forma sistemática aos escritos objetivos e condensados do próprio idealizador do Sistema 
Toyota de Produção, Taiichi Ohno e seu colaborador eventual Shigeo Shingo, procurando estar mais próximo da filosofia JIT.

Existe uma tentativa de abordar também alguns determinantes processuais como medidas governamentais e redes de empresas. Estes fatores fazem parte da história do sucesso do JIT no Japão, e são componentes que precisam estar presentes em qualquer panorama industrial duradouro. Tanto micro como macro fatores processuais necessitam estar integrados para uma ampliação sistêmica da eficiência do ciclo de fabricação.

O quarto capitulo apresenta os principais elementos do sistema JT. Buscou-se a não repetitividade de alguns aspectos já amplamente abordados na literatura. Embora o material seja bastante difundido, este caso trata de uma aplicação localizada.

O gerenciamento visual da produção é o assunto do quinto capítulo. Mais que uma discussão centraliżada no sistema Kanban apenas, o gerenciamento visual é colocado como uma ferramenta gerencial mais ampla e adaptativa, auxiliando de forma inovadora na administração da produção, mediante o auto controle e auto regulamentação.

O sexto capítulo conceitua o trabalho em grupos na produção, segundo a visão da administração japonesa e também conforme a abordagem socio técnica, uma escola de influência mais européia de equipes de trabalho.

O estudo de casos em uma tradicional indústria calçadista é apresentado no sétimo capítulo. Um breve diagnóstico de situação atual tanto do ambiente de chão de fábrica como em algumas atividades de apoio são expostos, e servem de matéria prima para proposiçôes de otimização. 
No oitavo capítulo são detalhadas as medidas de racionalização, apontadas como possiveis saneadoras do ambiente de fábrica. Entre outras medidas, são realçadas 0 gerenciamento vișual da produção e a transformação do trabalho individual para em grupos.

O nono capítulo detalha o processo de adequar o projeto idealizado à realidade. A implantação se faz de maneira gradual primeiro mediante um projeto piloto e posteriormente estendendo-se a outras seções da fábrica, de modo a contornar as limitações impostas pelo ambiente interno e externo. Os levantamentos dos primeiros grupos de trabalho e os primeiros resultados são expressos em diversas tabelas, permitindo um acompanhamento bastante interessante do processo de convencimento da aplicação das novas técnicas de produtividade.

No último capítulo são apresentadas as conclusões e as considerações finais pertinentes à dissertação apresentada. 


\section{CAPÍTULO 2:}

\section{O AMBIENTE INDUSTRIAL}

O objetivo deste capitulo é impostar a produção Just in time no contexto histórico da evolução do ambiente industrial. De forma sucinta e cronológica os principais fatos e teorias são registradas para uma compreensão das contribuições sequenciais dos eventos entre sí. Ressalta-se neste capitulo a condensação de transformações rápidas e intensas vividas a partir da revolução industrial até os dias atuais .

\section{1- Antiguidade e Idade Média.}

A evolução do ambiente industrial e a configuração dos ambientes de produção estão muito relacionados com os processos de trocas mercantis entre as civilizações e as necessidades geradas por demandas internas ou externas.

Remontam as civilizações antigas grandes empreendimentos tais como as obras egipcias, os carros de guerra com rodas e cidades sumerianas, o fabricação de objetos de vidro pelos fenicios e as construções gregas. Apesar de significativas sob o ponto de vista de organização e suntuosidade, a concepção destes empreendimentos estão conceitualmente bastante distante de um ambiente industrial. 
Na idade média ( 476 a 1453 d. C.) os feudos aparecem como organizações sociais fechadas, protegidas, de certa forma autônomas, de domínio hereditário, convenientes para uma época de comunicações lentas e combates corpo a corpo.

O trabalho era quase todo feito a mão. $O$ sistema de produção era artesanal. $O$ mestre artesão possuia os conhecimentos de concepção dos produtos e do processo de fabricação. Era senhor dos recursos de produção e auxiliado pelos aprendizes e companheiros. O núcleo de fabricação era pequeno e completamente dependente do mestre, em todos os aspectos. A demanda local era restrita e atendida plenamente pelas oficinas. A ausência de pressão de demanda não estimulava o aprimoramento das técnicas de produção. Variações nos fornecimentos eram fortemente controladas pelas corporaçôes de oficios, bem como qualquer modificação que pudesse alterar as relações sociais estabelecidas.

O domínio da igreja na Idade Média favorece as peregrinações aos lugares santos. Os caminhos percorridos até Roma, Palestina e outras localidades transformam-se em rotas comerciais com o Oriente.

Quando a Palestina passa para domínio turco, estes começam a hostilizar os cristãos e bloquear o fluxo religioso/comercial. Isto dá origem as cruzadas ( 1096 a 1270), movimento não só em defesa dos lugares santos, mas também conquistas de portos, terras e hegemonia de rotas comerciais. Crescem assim as transações comerciais entre o Ocidente e o Oriente.

No século XV alteraçôes importantes começam a acontecer. O intercâmbio de mercadorias intensifica-se. A indústria e o comércio fundamentam a nova economia. Aperfeiçoamentos nas fundições de metais e construções navais prefiguram nova fase que se consolida no Renascimento. As armas de fogo de lançamento, como canhões, vêem consolidadas a sua utilização e fazem sucumbir castelos e fortalezas como meio de defesa. As relações sociais começam a tomar nova forma, acentuando a formação de vilas e cidades fora de muralhas protetoras. 
Os grandes descobrimentos marcam o final da Idade Média e inicio do Renascimento. As novas rotas marítimas para a Índia, a descoberta das Américas em 1492 e demais descobrimentos tem grande impacto em toda a Europa modificando todo o cenário da época.

\section{2- Renascimento}

Este período assiste a consolidação das universidades, a reforma protestante, a ascensão de cientistas como Galileu e Descartes, artistas como Miguel Ângelo e Leornardo da Vinci, escritores como Maquiavel e posteriormente Shakespeare. A mudança de domínio do pensamento iriam brevemente alterar conceitos sociais, científicos e comerciais.

A pressão de demanda por produtos em maior quantidade, impulsionados pelas trocas mercantis decorrentes dos grandes descobrimentos, pressiona o método artesanal de fabricação. A expansão colonialista surge como novo fator condutor das transformações econômicas. Alterações bruscas na demanda trazem consequências que afetam todo o sistema de produção.

A necessidade de produtos passa a ser ditado por uma nova classe social, os mercadores. A solicitação de produtos ganha intermediações outrora inexistentes. $O$ mercado consumidor distancia-se fisicamente da fabricação, e os novos detentores dos pontos de contato começam a imprimir condições de fabricação. Os artesãos perdem gradativamente o controle sobre o que deve ser produzido, e também o modo como fazer chegar seus produtos ao gerador da demanda. Sua condição de agente e controlador absoluto começa a perder força. 
Posteriormente os próprios meios de produção seriam apropriados pelos mercantilistas. O como fazer, propriedade maior dos artesãos, é subjugado pelos novos detentores das relações comerciais e produtivas. $\mathrm{O}$ know how passa a ser alvo também de remuneração e propriedade de externos. Começam a surgir as grandes oficinas, orientadas precariamente pela organização do trabalho, em substituição das oficinas de artesãos.

A sistematização de conceitos apresentados em 1776 por Adam Smith em "A riqueza das nações" traz grande contribuição para o aumento de produtividade por meio da divisão do trabalho, conceito que Taylor em 1900 irá aprofundar e inovar. Isto permitiu que a produtividade de um fabricante de alfinetes aumentasse de 20 unidades/dia para 4.800 unidade/dia. Redução de custos significou aumento de demanda, maiores oportunidades de emprego e maior desenvolvimento social e industrial. Conforme SHINGO (. 1996, p. 322 ) " não existe fenômeno social que não tenha sido influenciado pela divisão do trabalho". Karl Marx também utiliza a obra de Smith como referência em partes de sua concepção político-econômica.

$\mathrm{O}$ movimento de independência das colônias inglesas em 1776 e a tomada da Bastilha em 1789 consolidam ideais de liberdade e igualdade de direitos, fundamentando a propriedade e iniciativa privada, gerando assim novos ciclos de desenvolvimento econômico.

Descobertas tais como a máquina a vapor, em 1781 por Watt na Inglaterra e o motor elétrico em 1834, por Davenport, nos Estados Unidos permitem a mecanização de algumas operações dependentes da força humana. Desenvolvem-se ferramentas para substituir as mãos e demais operações que demandam energia, aumentando a produtividade humana em patamares crescentes com progressões até aos nossos dias.

O conceito de padronização e intercambiabilidade aparece em 1790 por meio de Elí Whitney e a produção de mosquetões de guerra. Segundo COLENCI ( 1992) a 
substituição do conhecimento dos artesãos pelo conhecimento incorporado ao processo de fabricação, e as vantagens operacionais de construção e reposição, trazem novo esboço tanto para a concepção de produtos como para os processos de produção. Acentuam-se os registros de projeto de produto e processos de fabricação, conforme MARTINS \& LAUGENI (1998).

\section{3- A expansão industrial}

O tear mecânico é concebido em 1801 por Joseph Marie Jacquard. A independência dos conhecimentos do artesão mestre para a fabricação textil fica mais aparente ainda. $\mathrm{O}$ conhecimento, que é poder, migra das habilidades do artesão para o conhecimento de quem projeta e concebe a máquina. A fonte de conhecimento è poder muda de domínio.

A produtividade cresce de forma acentuada. Em um mercado comprador com demanda reprimida isto significa maiores acúmulos em menor tempo. Com o mercado favorável, o aumento de produtividade não implicava em desemprego, mas em reaproveitamento da força de trabalho em condições de vida cada vez piores, decorrentes da substituição do homem pela máquina e também da migração da populaçâo rural para as cidades, o que aumentava a disponibilidade.

O barco a vapor, a locomotiva a vapor, o motor elétrico, o esboço da máquina de calcular analitica, o telefone, a máquina de escrever, o motor de combustão interna de quatro tempos, a lâmpada elétrica, a usina termoelétrica, o automóvel com motor de 4 tempos, o motor díesel e muitas outras inovações caracterizam o período entre 1800 e 1900 como a fase da Revolução Industrial. Como afirma CANÊDO ( 1987 ), algumas manufaturas já contavam com 200 teares e com cerca de 600 funcionários. 
Charles Babbage por volta de 1830 projeta uma calculadora analítica, um protótipo do que seria o computador digital. Como matemático contribui para as primeiras mensurações do trabalho utilizando tempos associados a operações.

Todas estas alterações profundas são vivenciadas, algumas concomitantemente em um breve espaço de tempo. $\mathrm{O}$ ambiente de fábrica reflete esta profusão de inovações e conflitos, sendo palco de incorporações de novos procedimentos operacionais, e refletindo ainda as tensões sociais.

\section{4- A Administração Científica}

Grande movimento de idéias ocorrem no ínicio do século XX. Por volta de 1900 surgem estudos que marcam praticamente o início do estudo da administração como ciência. Estes novos conceitos e estudos são decorrentes de experiências e sistematizações de conhecimentos ocorridos no ambiente industrial. Da complexidade das fábricas a administração ganha alicerces para posteriormente "invadir" organizações não industriais.

Frederick W. Taylor inicia sua carreira profissional em 1878 como operário de chão de fábrica de uma grande siderúrgica e posteriormente torna-se engenheiro. Este histórico marca o direcionamento de seus estudos para a racionalização do trabalho operário, condensados no livro Princípios de Administração Científica, lançado em 1911. Ele decompõe o trabalho em pequenas partes, normaliza e padroniza os movimentos e reconstroe a macro operação com o rigor do cronômetro. Depois impõe o trabalho cientificamente analisado aos operários mais qualificados para a tarefa, buscando especialização. Divide ainda o trabalho entre funções de produção e funções de planejamento e controle. Suas teorias são complementadas por estudos realizados por Henry Gantt e pelo casal Frank e Lilian Gilbreth. 
$\mathrm{O}$ francês Henry Fayol, engenheiro de minas, consegue rápida ascensão profissional, sendo que em 1888, com 47 anos, é nomeado diretor de um conglomerado que reúne 9000 empregados. A necessidade faz com que Fayol apresente conceitos inovadores de integração entre as diversos departamentos nas organizações, o comando hierárquico, a integração de planos bem como a apresentação de princípios de administração e de gerenciamento, que repercutem até hoje nas organizações (WREN, 1994 ).

Henry Ford, em 1913, idealizou a linha de montagem e racionaliza operações de modo a permitir grandes volumes de produção com custos reduzidos. Padronizando materiais, equipamentos, mão de obra e produto final, inicia a produção em série ou produção em massa. Isto possibilitou a produção de 800 automóveis/dia em 1913, e o emprego de 150.000 pessoas em suas empresas, em 1926, com suas estratégias inovadoras de verticalização da produção, diversidade de negócios e integração das cadeias de produção, comercial e de assistência técnica .

O estilo de produção imprimido por Ford padronizava também o consumo do mercado através da fabricação em série. $O$ mercado era forçado a consumir o que a fábrica produzia. A área comercial, de certa forma, fica submissa a área de manufatura.

Muitas inovações, realizadas quase simultaneamente, provocam uma mudança no ambiente industrial. É uma época de conceituações inovadoras que rompem com conceitos empíricos vigentes. $\mathrm{O}$ ambiente de fábrica começa a refletir de forma mais contundente a divisão do trabalho e a especialização, o cientificismo e padronização dos métodos de produção, o rigor do controle de operações e eficiência na utilização de recursos. É um período de revolução de modelos mentais, onde o homem passa a ser concebido como um recurso de produção, sujeito também a normalização de procedimentos, intercambiabilidades, integrações e otimização de suas qualificações. Quando incorporadas estas inovações, a produtividade industrial cresce de forma sensivel. 
2.5- O Período entre e pós guerras mundiais.

A primeira guerra mundial, de 1914 a 1918, enfraquece economicamente os países europeus, que tem seus esforços industriais direcionados para o setor bélico. Isto favorece a consolidação da indústria americana como fornecedora de produtos manufaturados para os países, sem o revés de participar das destruições decorrentes .

Elton Mayo e sua equipe iniciam em 1927 os estudos na fábrica em Hawthorne, terminados em 1932, e que causariam uma grande mudança no ambiente de produção. Observam que conceber o homem apenas como um agente econômico, uma engrenagem em uma máquina, motivado apenas pelo volume de produção para poder ganhar mais, é uma visão parcial no espectro da produtividade. Outros fatores igualmente importantes estão presentes e que influenciam o comportamento do operário, tais como as relações humanas, o estilo de liderança e as variáveis envolvidas na motivação. Estes estudos lançam bases para um equilibrio entre a lógica da eficiênçia e a não lógica dos sentimentos dos trabalhadores, como observou WREN ( 1994 ). Com o foco na produtividade, o ambiente de fábrica ganha contornos mais humanos, balanceando a visão cientificista do trabalho. O sistema Just in time na década de 70 vai ampliar o papel estratégico do homem no processo de produção.

A segunda grande guerra mundial, de 1939 a 1945, trouxe grandes transformações que são bases para a atual composição política e econômica. $O$ esforço de guerra primeiramente efetuado pelos paises europeus e posteriormente acrescidos pelos Estados Unidos em 1941, direciona a fabricação para a indústria bélica, não se resumindo apenas a armamentos em sí, mas também a tecnologias. A demanda por produtos confiáveis aumenta consideravelmente, favorecendo a utilização de técnicas de controles estatísticos de qualidade e departamentos de controle da qualidade. Nomes como Willian Edwards Deming, e posteriormente 
Armand V. Feingenbaum e Joseph M. Juran, começam a se destacar nesta nova filosofia de qualidade no chão de fábrica.

Também neste período desenvolvem-se os primeiros computadores eletro mecânicos (1936), eletro magnético (1944) e a válvula (1946), objetivando maior rapidez no processamento de informações balísticas. A capacidade de armazenar e processar informações com grande velocidade, aliados a miniaturização de componentes como o transistor em 1947, e demais circuitos eletrônicos permitirão em um curto espaço de tempo a automação de máquinas ferramentas e o desenvolvimento de computadores que inovarão a gestão da produção.

Com a finalização da $2^{\circ}$ Guerra Mundial os países passam por um período de reconstrução nacional, vivendo a indústria um período de alta demanda, e um certo relaxamento com os desperdícios e a qualidade ( MAXIMIANO, 1995 ). Com o mercado ávido por mercadorias, desperdícios na produção não eram relevantes, em face da alta lucratividade dos produtos industrializados. Este panorama prevalece por um breve espaço de tempo até o impacto proporcionado pela indústria japonesa com o sistema Jlist in time.

Em 1950 o Japão no esforço de reconstrução de seu parque industrial convida Deming para uma visita por intermédio de uma associação de classe. Os conceitos sobre qualidade sistematizados por este americano são assimilados pelos japoneses de forma muito intensa e transformadora. Deming transforma-se num ícone dos empresários japoneses, e retorna ao Japão quase todos os anos até a sua morte em 1993. Juran também visita o Japão em missões educativas diversas vezes. O impacto da qualidade logo começa a ser sentido nos produtos fabricados pelos japoneses. Arquiteta-se um dos fundamentos do sistema Just in time: o Controle Total da Qualidade, TQC, termo consagrado por Feigenbaum em 1961. 
2.6- A década de 70 até os nossos dias

Fazendo referência a este periodo, CORIAT (1988, p.19). afirma: “ Enquanto os mercados eram globalmente regidos pela demanda até os anos 60 significando para as empresas que a saida de produtos estava garantida, com a demanda sendo superior à oferta -, nos anos 70 esta situação inverte-se e os mercados tornam-se globalmente regidos pela oferta: as capacidades instaladas são superiores a demanda ".O mercado passa por um ponto de inflexão. A capacidade instalada supera a demanda, trazendo grandes alterações ao ambiente industrial

Produtividade e competitividade passam a ser fundamentos buscados nas organizações, como condição de sobrevivência empresarial. A concorrência oferta ao mercado produtos variados e diversificados, com custos cada vez mais baixos.

A teoria dos sistemas reforça a importância das influências externas na determinação dos planos de manufatura. A força determinante do mercado, e o esforço das empresas industriais em serví-lo segundo suas necessidades, não impondo ao mercado um padrão de consumo como fazia Ford, direcionam os planos estratégicos. Acentua-se o foco no cliente.

MICHALET ( 1984, p.22 ) observa que na década de 70 surge uma nova estrela na cena internacional. A empresa multinacional pode ser definida como " uma grande empresa nacional que possui ou controla várias filiais de produção em vários países". Este fenômeno não é novo, mas intensifica-se neste periodo principalmente entre as empresas americanas. Os fatores principais apontados para esta expansão são: a existência de disparidades regionais, a estrutura oligopólica dos mercados, a vantagem tecnológica e a diferenciação dos custos de produção. $\mathrm{O}$ mercado altera-se de uma economia internacional para uma economia mundial, sem fronteiras geográficas, sendo irrelevantes as diferenças politicas e ideológicas. 
Segundo CORIAT ( 1988, p.14) " a segunda metade dos anos 70 marca um processo claramente irreversivel na indústria manufatureira, relativo ao deslanchar das novas formas de automação “. A tecnologia de automação cria condições para o desenvolvimento de máquinas ferramentas automatizadas de controles numéricos, interfaceando os equipamentos com os computadores

Soma-se a isto a evolução e o barateamento dos meios de manipulação da informação com o surgimento dos microcomputadores e outras máquinas com altíssimo poder de processamento com preços acessíveis, aliado ao desenvolvimento de softwares de desenvolvimento e comunicação. Estes fatores fornecem as condições necessárias para o surgimento de sistemas auxiliados por computadores ( $\mathrm{CAD}$, CAM, CAE ) e o desenvolvimento da manufatura integrada por computador, o CIM.

Sistemas automatizados de gestão da produção e materiais viabilizam-se operacionalmente com a oferta de novos hardwares. $O$ desenvolvimento $e$ implantação de sistemas Material Requirement Plamming, MRP I, e Manufacturing Resources Planming, MRPII, intensificam-se também neste período, num primeiro momento entre as empresas americanas e posteriormente em todo o mundo. Surgem programas de gestão empresarial integrados, que comprometem-se com a informatização e integração de todas as funções do negócio.

Em termos de organização do trabalho, o taylorismo dá sinais de esgotamento em seus esforços de parcelamento, especialização e intensificação do trabalho. Algumas causas podem ser observadas, tais como a instabilidade social causada pelo emprego de " grandes massas de trabalhadores não qualificados, submetidos a ritmos de trabalho muito intensos, frequentemente acompanhados de más condições de trabalho" CORIAT ( 1988 p. 16 ) e a não adequação a necessidade de flexibilidade requerida pelo mercado. Novas formas de organização industrial são pesquisadas por diversas empresas. 
Conceitos simples são apresentados por GOLDRAT ( 1984), que ele denomina de Teoria das Restrições. A conceituação dos gargalos de produção, a subordinação das operações de fábrica e a capacidade de processamento do fator de restrição influenciam o modo de pensar da administração da produção.

É neste cenário histórico que a indústria japonesa, desmontada pela segunda guerra, surpreende o mercado mundial fornecendo produtos de alto valor agregado com preços extremamente competitivos. Os padrões de qualidade verificados tornamse fatores diferenciais, assim como a superioridade das técnicas de fabricação, altamente responsiva as necessidades do mercado. Consolida-se o sistema Just in time de produção, motivo de aprofundamento do próximo capitulo.

A intensificação da concorrência internacional verificada com o processo de globalização tem levado as organizações a se confrontarem de forma acirrada com a necessidade de rápidas adaptações e flexibilidade. As circunstâncias, ou contingências, levam as empresas a buscarem novas arquiteturas organizacionais que são mais apropriadas para o momiento que a organização vive. Modelos prontos, por melhores que se apresentam, são aplicados contingencialmente. As empresas precisam aprender a aprender com as mutações e inovações tecnológicas deste novo cenário de competitividade.

A organização tradicional, hierarquizada e burocrática, tem sido alvo de estudos que preconizam sua falência e que visualizam sistemas administrativos bem diferentes dos observados atualmente. $\mathrm{O}$ início do século XXI será caracterizado por organizações ágeis e estrutura flexivel, com rotação e redefinição de funções constantes organizadas por processo de alto desempenho, articuladas por meio de poderosas redes empresariais, conforme GIBSON et al. ( 1998 ). 


\section{CAPÍTULO 3:}

\section{O SURGIMENTO DO SISTEMA JUST IN TIME}

A produção Jist in time surge dentro de um amplo contexto de fatores históricos e econômicos que precisam ser entendidos em suas interações e complexidade. O objetivo deste capítulo é contribuir para uma melhor compreensão dos fatores fundamentais que contribuiram para o surgimento do JT no Japão, e mais particularmente na Toyota Motors Company. A interação destes agentes determinantes é muito importante para o próprio assentamento do sistema JT dentro de uma visão ambiental muito mais ampla do que aquela restrita ao chão de fábrica.

\section{1 - Fundamentação_histórica e cultural do Japão}

O Japão é um país com área de $372.480 \mathrm{~km} 2$, aproximadamente uma vez e meia a área do estado de São Paulo. Sessenta por cento desta área compreendem montanhas com florestas. A área agriculturável é de apenas $15 \%$. Não há recursos naturais como o petróleo, carvão, ferro etc. O espaço, a área cultivável e os recursos naturais são extremamente escassos.

No final da segunda guerra o país estava completamente arruinado, com muitas cidades destruídas por completo e a população vivendo em barracos. O plano Marshal de apoio a recuperação pós guerra foi fundamental para a reação na nação nipônica. Porém como compreender, passados 25 anos, o grande salto de 
competitividade das empresas japonesas, destacando-se muitas delas como líderes mundiais em seus segmentos de atuação?

Segundo YOSHIMOTO (1992 ), apesar do Japão ser reconhecido como um país industrial somente depois da segunda guerra, os fundamentos para a recuperação nacional podem ser observados em princípios culturais muito antigos.

A NIPPON STEEL CORPORATION ( 1984 ) cita uma carta de juramento do imperador Meiji datada de 1853, cujo objetivo era romper um isolamento de quase trezentos anos. Ela é constituida dos seguintes cinco artigos:

1) Em todos os negócios de Estado, a opinião pública será ouvida através de consultas gerais

2) Governo e povo agirão em harmonia, executando com energia as questões administrativas

3) Nenhum cidadão, civil ou militar, será desencorajado na busca de suas aspirações

4) Más práticas do passado serão abandonadas e a justiça universal deverá prevalecer

5) Os alicerces do regime imperial deverão ser fortalecidos pela aquisição de conhecimento em todo o mundo.

Estes princípios assemelham-se com diversas missões empresariais atuais, de simples entendimento, objetivos e facilmente assimiláveis. Observando o conteúdo dos artigos, percebe-se: a necessária harmonia entre o público e o privado; a visão aberta as necessidades do mercado; a ênfase na criatividade e esforço pessoal e a humildade em buscar conhecimentos onde necessário. Estes elementos, culturalmente arraigados, foram fundamentais para a modernização da indústria japonesa.

No esforço de reconstrução pós guerra, entidades japonesas convidaram especialistas americanos em controle de qualidade, como citado anteriormente. $\mathrm{O}$ 
reconhecimento do trabalho de Deming, por exemplo, foi muito mais marcante no Japão do que em sua própria pátria. O governo enviou maciçamente jovens japoneses para estudar em universidades americanas e européias.

Em 1947 o sistema educacional foi completamente remodelado, passando o ensino obrigatório para 9 anos. Hoje o percentual de matriculados em escolas técnicas ou universidades ultrapassa $37,4 \%$, e a frequencia de crianças no ensino obrigatório é de $100 \%$. Atualmente o investimento médio nos estudantes de primeiro e segundo grau é de U\$\$ 5.223,5 por ano, enquanto que no Brasil este índice situa-se em torno de U\$\$320,00. ( UNESCO, 91 ).

Fatores como influência cultural, educação continuada, busca de capacitação tecnológica no exterior e disciplina sacrificial comunitária fornecem alguns elementos que, somados a restrições de recursos de todos os tipos, contribuiram grandemente para o desenvolvimento do sistema Just in time de produção.

\section{2- O ambiente que proporcionou o crescimento pós-guerra}

A grande desorganização causada pela guerra proporcionou no Japão a oportunidade de reorganização industrial bastante abrangente, não envolvendo apenas o chão de fábrica. Este mesmo mecanismo foi observado em alguns outros países de forma mais efêmera e fugaz, como na Inglaterra, conforme BURNS \& STALKER ( $1961)$.

As estratégias e politicas de desenvolvimento industrial contribuíram marcantemente para esta nova configuração de desenvolvimento, bem como a rápida absorção das alterações ambientais com composições de soluções sinergéticas . 
Como observa FLEURY \& FLEURY ( 1997 ), com a rendição do Japão, as forças de ocupação intervieram de forma radical no país, sendo que uma das medidas principais foi o desmantelamento dos zaibatsu, que eram grandes grupos industriais ligados as famílias mais tradicionais. Esta iniciativa é de certa forma frustrada com o advento da Guerra da Coréia, quando os americanos passam a depender da base industrial do Japão para apoio no conflito.

Como resultados deste novo procésso bélico, apresentam-se os seguintes resultados: Os zaibatsu são reformulados, com o dominio das instituições financeiras e tradings; esforço para renovar as pequenas e médias empresas e a criação do Ministry of International Trade and Industry, MITI, como condutor da política industrial e da reindustrialização do país.

Para os autores, o MITI passa a atuar de forma bastante eficiente nos contratos de transferência de tecnologias, interferindo também na indução de desenvolvimentos industriais, criando condições de competição no mercado interno mediante associações grupos lideres mundiais com os empresários locais, enfatizando a absorção e transferência de tecnologia. Somente as empresas competitivas no mercado interno obtinham autorização da Japan Industrial Standard, JIS, para a exportação. A demanda interna era protegida com restrições às importações e estímulo à qualidade identificada pelos consumidores mediante os selos da JS, com a consequiente alteração da imagem externa dos produtos japoneses.

Em meados da década de 60, diretrizes do MITI de concentrar exportações e ganhar volume de produção levam as empresas a se associarem, gerando forte interação entre os empresários locais. Planos estratégicos são estabelecidos em conjunto, competências são compartilhadas e as fusões tecnológicas entre as próprias empresas impulsionam o desenvolvimento.

Em 1973 a crise do petróleo, para um país dependente energeticamente, acentua a inter relação empresarial na busca da racionalização dos recursos escassos, 
redução do consumo de energia e combate ao desperdício. O fluxo de informações entre clientes, fornecedores, instituiçôes financeiras e empresas é intenśificado. Estes acontecimentos acabam criando uma permeabilidade muito grande, tanto entre as empresas como também com os conglomerados financeiros. AOKI ( 1990 ) observa que parece não haver clara separação hierárquica entre a empresa produtiva e a instituição financiadora .

Conforme IMAI ( 1990 ) o processo de desenvolvimento da indústria japonesa " evolui da inovação em processo para a inovação sistêmica, com uma mudança organizacional associada, de sistema mecânico para rede orgânica “.

Esta imposição ambiental é importante para o entendimento do desenvolvimento das novas filosofias de produção. Estas não nascem e se consolidam por sí só. As respostas rápidas, criativas, inovadoras e sinergéticas dadas como respostas necessárias as alterações ambientais talvez sejam a base do desenvolvimento da indústria japonesa, com inovações na gestão do ambiente de produção e desenvolvimiento de produtos com diferenciais tecnológicos.

O processo observado no Brasil, de substituição de importação, criou um processo de industrialização e desenvolvimento tecnológico' subserviente ao capital estrangeiro, sem vínculos com Institutos de Pesquisas ou Universidades locais como observa COLENCI ( 1992 ). Os parceiros industriais repassaram a indústria nacional tecnologias já depreciadas e disponiveis nos países de origem, mantendo sempre a dependência e o atrelamento tecnológico/econômico, criando assim dificuldades sistêmicas adicionais ao desenvolvimento nacional.

\section{3- A Toyota Motor Co}

Neste amplo cenário de composições ambientais dinâmicos, o histórico da Toyota Motors Co, TMC, é um destaque. As experiências bem sucedidas em seu 
parque fabril permitiram a assimilação de sua filosofia de trabalho por outras empresas japonesas e posteriormente por empresas de todo o mundo. Os resultados obtidos extrapolaram o ambiente fabril, ganhando contornos em todos os campos da administração. A história do sistema Just in time, JT, é de certa forma a história da TMC.

A indústria automobilística Toyota tem suas raizes no segmento textil, através da Toyoda Spinning and Weaving, que fechou em 1942. Toyoda Sakichi, o patriarca da empresa, era muito observador e um astuto inventor. Foi o criador em 1926 do tear auto ativado, com dispositivo de parada automática quando qualquer fio se rompesse. Esta patente foi vendida para uma empresa Inglesa em 1930, e todo o dinheiro foi revertido para pesquisa de automóveis.

O interesse por automóveis surgiu quando Sakichi foi visitar os Estados Unidos em 1910 e por lá circulavam os primeiros Ford modelo T. Retornou em 1911 e também percorreu a Europa. Decidiu então que fabricaria automóveis, ciente das grandes dificuldades que encontraria, mas vendo paralelos entre a indústria textil ẹ a indústria automotiva, tais como o funcionamento automático acionado por uma máquina.

Depois de muitos estudos, trabalho de preparação e frustrações como aquele imposto pelo governo militar de proibir a construção de carros de passeio, em 1933 foi constituída a empresa de fabricação de automóveis e em 1937 foi fundada a Toyota Motor Company, por Toyoda Kiichirõ, filho de Sakichi. O nome "Toyoda " significa campo de arroz abundante, e foi mudado para "Toyota" com fins mercadológicos.

Segundo OHNO ( 1997, p.101) "O caminho de Toyoda Sakichi para Toyoda Kiichirõ e depois para a atual Toyota Motor Company é o caminho da moderna indústria japonesa, que está se desenvolvenendo e amadurecendo. A linha que os une é a busca de uma tecnologia de origem japonesa ". O nacionalismo foi um 
traço sempre presente nos fundadores da Toyota. A busca por métodos japoneses de pensar e fazer foi sempre perseguido. Construir uma consciência nacional de criatividade e tecnologia própria tranformou-se em objetivo pessoal destes inovadores.

Em 15 de agosto de 45 o Japão perde a guerra. Kiichirõ então lança um marco divisor de épocas para a Toyota, conforme afirma OHNO ( 1997, p. 25 ) : "Alçancemos os Estados Unidos em 3 anos. Caso contrário, a indústria automobilistica do Japão não sobreviverá ". A produtividade do trabalhador japonês era mediocre quando comparado com o americano, algo em torno de 10 vezes menor. Combate ao desperdício, esta foi a necessidade maior que fez nascer o sistema Toyota de produção.

Em 1949 uma grande crise atinge a empresa. Kiichirõ renuncia a presidência da empresa, que atendendo a determinação do Banco do Japão dispensa 1.600 operários. Em consequência das negociações realizadas na época, a TMC passa a garantir emprego vitalicio e também progresso salarial por senioridade. Estas negociações agregaram componentes que precisaram ser absorvidos pelo sistema de produção.

Diante desta situação de riscos, todas as operações de fábrica foram remodeladas. Taiichi Ohno e equipe, fundamentados nos princípíos de Sakashi e Kiichirõ, iniciam o processo de transformação do processo de produção.

Conforme FLEURY \& FLEURY ( 1997) a estruturação do Sistema Toyota de Produção, STP, foi ocorrendo lenta e gradualmente, através de um processo inteligente de experimentação e aprendizagem.

Foi durante a crise de petróleo verificada na década de 70 que a superioridade do sistema Toyota pode ser verificada, diante de competidores tradicionais do mercado automotivo. Os resultados obtidos pela TMC surpreenderam aos analistas de 
mercado. Nesta época o STP já contava com um histórico de quase 30 anos de pesquisas, experimentos, desenvolvimentos e inovações.

Atualmente o mercado automobilístico mundial passa por um processo de complexidade. Uma competitividade acirrada é percebida entre empresas americanas, européias, coreanas e japonesas. A-margem de lucratividade vem caindo sensivelmente. SHIMOKAWA ( 1993, p. 9-11) analisa que " três das onze montadoras japonesas foram para o vermelho. O lucro total das montadoras japonesas caiu $50 \%$, de cerca de US 10 bilhões durante os anos de pico para US 4,5 bilhões. Mesmo a Toyota Motors Co., a mais forte das montadoras japonesas, não conseguiu impedir que seus lucros despencassem rapidamente de mais de US\$ 6,3 bilhões para apenas US\$ 2,7 bilhões"

Estas mudanças ambientais levaram a Toyota a implantar em 1992 uma nova planta fabril na cidade de Kyushu, com mudanças significativas no difundido STP, com aperfeiçoamentos técnicos, ecológicos e humanos: $O$ processo de combate ao desperdicio, aperfeiçoamento, adaptações as alterações ambientais, experimentos e adaptações continuam na TMC. Alguns analistas julgam que enquanto a própria TMC divulga seu sistema STP como um novo paradigma, internamente e empresa já trabalha com inovações que alteram substancialmente seu modelo de produção.

\section{4- O termo Just in time}

O STP tem como objetivo o combate sistemático ao desperdicio. Para tanto dois conceitos são fundamentais:

1- Autonomação, que tem como raiz a palavra autonomo, e pode ser entendido como a automação com um toque humano. Faz-se presente a influência de Toyoda Sakichi. 
2- Just in time, termo utilizado por Toyoda Kiichirõ, instrumentalizado e consagrado posteriomente por Taichi Ohno .

Em 1933, juntamento com o objetivo de desenvolver automóveis, Kiichirõ disse (OHNO, 1997, p. 103 ) : “Nós aprenderemos técnicas de produção do método americano de produção em massa. Mas nós não iremos copiá-las como são. Usaremos as nossas próprias pesquisas e criatividade para desenvolver um método de produção que seja adequado à situação do nosso próprio país".

FUJMOTO ( 1994 ) afirma que " muito embora não existissem métodos concretos, Kiichirõ insistia fortemente para que os departamentos à jusante deveriam solicitar apenas a quantidade que eles necessitassem. Ao iniciar as operações na área automobilística, Kiichirõ mandou fixar as palavras Just in time nas paredes, e comandava seus subordinados para que recebessem apenas 20 blocos de motor pela manhã, e nada mais, se fosse essa a quantidade necessária para o dia “. Aqui apresenta-se a iniciativa geradora do sistema JIT.

"Just in time significa que, em um processo de fluxo, as partes corretas necessárias à montagem alcançam a linha de montagem no momento em que são necessárias e somente na quantidade necessária. Uma empresa que estabeleça esse fluxo integralmente pode chegar ao estoque zero" (OHNO, 1997, p. 26 ).

"JIT é um meio de eliminar estoque, ou seja, um meio de eliminar a perda por superprodução. ЛT significa produzir o necessário, quảndo necessário, na quantidade necessária. " ( SHINGO, 1996a, p. 325).

" ЛТ significa que no processo de montagem das peças e componentes necessários para montar um carro, os tipos de submontagens necessárias do processo precedente devem chegar da linha de produção no tempo necessário e nas quantidades necessárias " (MONDEN, 1984, p. 3 ). 
Foram estas filosofias simples a base do sistema de produção que marcaram uma nova forma de organizar a produção. A novas configurações de chão de fábrica e de administraçãó da produção tomaram forma tal que confundiram os primeiros industriais americanos em visitas as fábricas japonesas. "Eles viram conceitos e técnicas de fabricação sendo utilizados no Japão que às vezes assumiam formas diametralmente opostas às nossas" ( SCHONBERGER, 1988, p. XV).

Conforme CORIAT ( 1988 ) O sistema Just in time parece assimilar uma nova mudança de paradigma de produção . O paradigma taylorista/fordista busca a intensificaçâo do trabalho, pois este componente é uma variável vista como estratégica na composição dos custos de produção. O novo paradigma move-se em direção a gestão do capital fixo e do capital circulante, enfatizando não a organização do trabalho, mas a organização da produção.

Alguns autores afirmam que a produção JT " é uma forma superior dos seres humanos fazerem as coisas. Gera melhores produtos, em maior variedade, a um custo mais baixo. Igualmente importante, proporciona um trabalho mais estimulante e satisfatório a funcionários de todos os niveis" ( JONES et al. , 1990, p. 225 ). 


\section{CAPÍTULO 4: \\ ELEMENTOS DO SISTEMA JUST IN TIME}

O objetivo deste capítulo é a fornecer uma visão dos principais fundamentos do sistema JT. Por ser um assunto já bastante estudado, foram tomadas algumas precauções para se evitar o enfado da repetitividade, tais como: a rápida citação de alguns elementos quando já exaustivamente documentados; a máxima utilização de autores japoneses na fundamentação teórica e a utilização de uma abordagem crítica e reflexiva de alguns princípios do sistema $Л \mathrm{~T}$

\section{1- Introdução}

O sistema Toyota de Produção apoia-se sobre dois pilares: A Autonomação e o Just in time.

A autonomação é um conceito diferente da automação. Pode ser entendido como a automação com um toque humano, ou máquinas com dispositivos de paradas automáticas quando alguma anormalidade é detectada. A inteligência humana é acoplada a máquina. Estes mecanismos estão presentes em máquinas novas e já depreciadas também.

“A autonomação também muda o significado da gestão. Não será necessário um operador enquanto a máquina estiver funcionando normalmente. Apenas quando a 
máquina para devido a uma situação anormal é que ela recebe atenção humana. Como resultado, um trabalhador pode atender diversas máquinas, tornando possivel reduzir o número de operadores e aumentar a eficiência da produção" ( OHNO, 1997, p. 28).

Na conceituação do sistema JIT, a simbiose com a autonomação é perceptivel, como por exemplo nos dispositivos baka yoke que impedem a produção de produtos fora da especificação. Esta sinergia é muito importante para o bom desempenho de um linha de produção.

O foco desta dissertação é o sistema JIT e sua contextualização em ambiente brasileiro. Assim aspectos mais especificos de autonomação não serão abordados. Como visto no capítulo anterior, o histórico do JT confunde-se com a história da TMC..

\section{2- Eliminação do desperdício}

Eliminar desperdícios é um princípio obviamente não exclusivo do sistema JT. A forma como é perseguido sistematicamente pela administração JIT, como uma verdadeira obsessão, torna este aspecto muito relevante no entendimento do sistema.

Podemos afirmar que a essência do STP e do JT é o combate sistemático ao desperdício. "O STP é fundamentaimente baseado na absoluta eliminação dodesperdício " ( OHNO, 1997, p. 38 ). Qualquer tipo de desperdicio precisa ser insistentemente eliminado dentro da organização, tornando-se este o primeiro objetivo da empresa. Combater o desperdício significa reduzir os custos de produção.

OHNO ( 1997, p. 39 ) classifica os desperdicios en 7 grupos: 
desperdicio de superprodução;

desperdício de tempo disponível;

desperdício em transporte;

desperdício do processamento em si;

desperdício de estoque disponivel;

desperdício de movimentos e

desperdício de produzir produtos defeituosos

\subsection{1- Desperdício de superprodução}

É toda produção realizada sem demanda real. No ambiente de fábrica é comum o hábito de antecipar-se a uma possivel demanda futura. $O$ conceito de lote econômico de fabricação de certa forma induz os operários do chão de fábrica a produzirem sem demanda real, com o argumento de melhor utilizar os equipamentos com restrições de produção.

SHINGO ( $1996 a$ ) identifica dois tipos de superprodução: Quantitativa e antecipada. A primeira ocorre quando é produzido uma quantidade maior que a necessária, e a antecipada quando o produto é feito antes que o necessário.

O tempo de set-up é um dos fatores que podem levar a superprodução, porisso os projetos de redução de tempo de set-ups são tão importantes na produção ЛT.

A superprodução é evitada com um sistema de produção que trabalhe com planejamentos fáceis de serem alterados, pequenos lotes de produção e sistemas que atendam rapidamente as alterações de demanda. 
A definição do JT de produzir apenas o necessário não coaduna com nenhum tipo de produção em excesso.

\subsection{2- Desperdício de tempo disponf́vel}

Também entendido como desperdício causado por qualquer tipo de espera, de forma especial a espera de material. Se decomposto o Lead Time de produção, $95 \%$ do tempo de permanência do produto semi elaborado no chão de fábrica é atribuído a espera por processamento. Isto é perceptivel principalmente nas produções Just In Case.

“ A filosofia ЛT coloca a ênfase no fluxo de materiais, e não nas taxas de utilização dos equipamentos, os quais somente devem trabalhar se houver necessidade. A sincronização do fluxo de trabalho e o balanceamento das linhas de produção contribuem para a eliminação deste tipo de desperdício " ( CORRÊEA \& GIANESI, 1993, p. 68).

\subsection{3- Desperdício em transporte}

O transporte não agrega valor ao produto, e deve ser minimizado ao máximo. Toda movimentação precisa ser criteriosamente analisada, se possível eliminada ou combinada com uma operação efetiva de produção. " A melhoria na operação de transporte pode ser obtida em duas etapas: lay-out de máquinas e adoção de um meio de transporte rápido “ ( MONDEN, 1984, p. 41 ). A ênfase no processo de fabricação leva ao desenvolvimento de plantas de fábrica que reduzem consideravelmente operações de transporte. 
Criticando algumas iniciativas de somente automatizar meios de transporte SHINGO ( $1996 a$, p. 78 e 79 ) comenta que " substituir transporte manual por transporte mecanizado é um tipo de melhoria. Mesmo assim, ter que deslocar materiais permanece sendo uma operação que aumenta o custo. Transporte por meios mecânicos pode reduzir o montante desta perda, mas ainda é uma perda. Por isso é muito importante otimizar o lay-out da fábrica de maneira tal que a necessidade de deslocar materiais é minimizada ou eliminada ".

\subsection{4- Desperdício de processamento em sí}

A busca da racionalização dos mecanismos de processamento está relacionada com os estudos dos métodos de produção, mediante planilhas de análise de fluxo, fluxogramas de fabricação, cartas de processos e estudos de tempos e métodos . Entende-se processo como um eixo independente de operações, conforme ilustra a figura 4.1. Melhorar o processo é uma tarefa que vem antes de melhorar ạs operações.

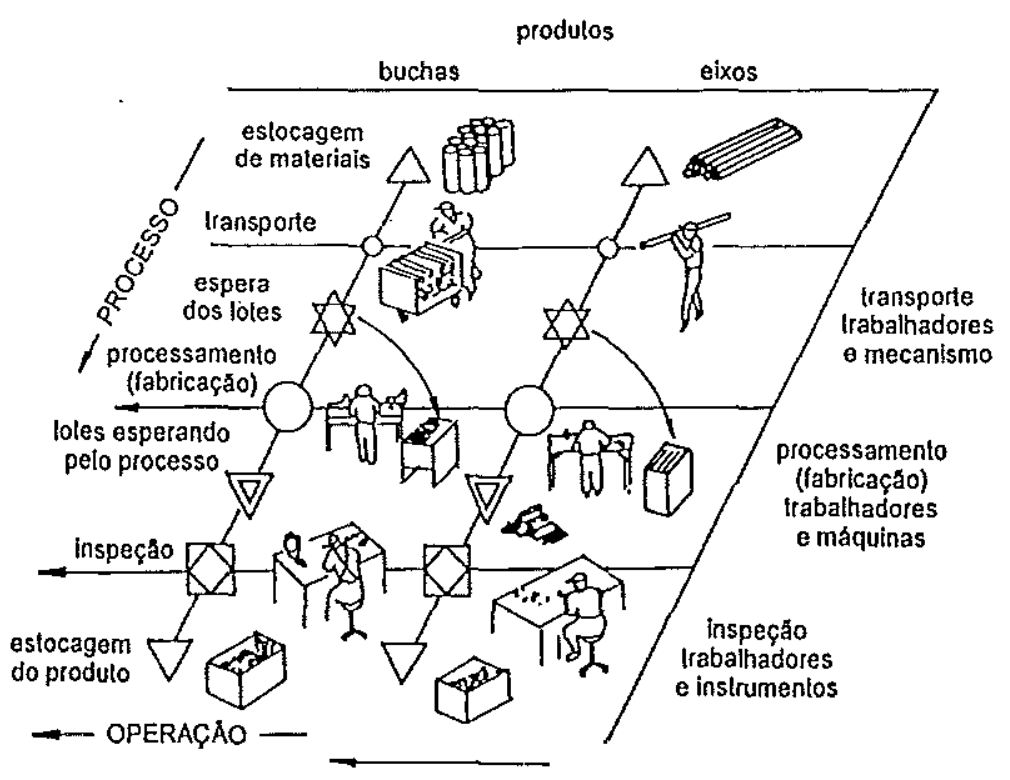

Figura 4.1: Diferenciação entre operações e processos

Fonte: Shingo ( 1996b: 38 ) 
As clássicas técnicas e perguntas $5 \mathrm{~W}$ e $1 \mathrm{H}$ (Why, What Where, When, Which e How ), com possibilidades de combinar, eliminar ou modificar componentes do processo de fabricação são instrumentos de auxilio para reduzir os desperdicios de processamento.

OHNO ( 1997 ) comenta que na Toyota $5 \mathrm{~W}=1 \mathrm{H}$. Achar as verdadeiras causas dos desperdicios vem quando torna-se um hábito perguntar Por que 5 vezes . Assim procedendo chega-se ao como fazer. 5 Por ques é igual a 1 como fazer.

\subsection{5- Desperdício de estoque disponível}

Estoque de materiais são vistos como estoque de ineficiências. Shingo em suas obras enfatiza este ponto de maneira insistente, chegando a denominar uma nova revolução industrial que ele chama de era da produção com estoque zero .

Além do investimento de capital de giro em sí, o estoque oculta desbalanceamentos da linha de produção e potenciais vazamentos de recursos operacionais. Uma deliberada retirada de estoques é salutar para o aparecimento de gargalos na produção.

Combater os estoques requer o que OHNO ( 1997 ) chama de revolução na consciência entre os empresários, que resulte em mudanças de atitudes fundamentadas no bom senso e coragem. 


\subsection{6- Desperdício de movimentos}

Desperdícios de processamento levam o foco ao processo, ao passo que os desperdicios de movimento trazem o foco para as operações em sí. A visão da tãrefa em sí é também foco de racionalizações. Anterior a qualquer processo de autonomação é imprescindivel a otimização de processos e de movimentos de tarefas.

Os critérios e ferramentas para evitar desperdícios de processamento também aplicam-se ao esforço de racionalizar as tarefas.

Toda normalização de trabalho desenvolvida por Taylor é muito aplicada nos processos JT. Assim micro economia de tempos são avaliadas com empenho pelos operários.

\subsection{7- Desperdício de produzir produtos defeituosos}

Os custos decorrentes da produção não conforme são muito expressivos. Envolvem não apenas a matéria prima em sí, mas todo trabalho já agregado no produto, tais como hora máquina, hora homem, armazenagem, todos os recursos de retrabalho e reprogramações.

Fazer certo da primeira vez é o axioma que reduz os desperdícios decorrentes da produção defeituosa. Um rigido programa de qualidade no processo com envolvimento de todos os funcionários da empresa, denominado de Total Quality Control, TQC, consolida os atributos da qualidade dentro da organização.

Algumas ferramentas associadas a estas estratégias de qualidade são muito difundidas, tais como os Círculos de Controle de Qualidade, CCQ, e os dispositivos 
que impedem a fabricação de produtos defeituosos no chão de fábrica, os sistemas baka yoke.

Porém as ferramentas não podem ser confundidas com o TQC em sí, pois este é de uma amplitude muito maior, envolvendo todos os níveis organizacionais e que engloba todos os processos empresariais.

\section{3- Processo de melhorias contínuas}

O processo de melhorias contínuas é denominado de Kaizen. Segundo IMAI ( 1990 ), esta é a diferença mais importante entre a administração ocidental e a administração japonesa. $\mathrm{O}$ foco da diferença está no processo de melhorias contínuas intensamente buscado por funcionários de todos os escalões das empresas, muita vezes inconscientemente. Ele atribui todas as práticas administrativas japonesas como componentes de um quadro maior chamado Kaizen, incluindo o próprio JT.

BARÇANTE ( 1998 ), comenta que a qualidade quando discutida no contexto de Kaizen refere-se a qualidade das pessoas, não a qualidade do produto. $O$ agente fundamental nestes processos de melhorias é o elemento humano.

Todos estão empenhados em buscar melhorias em todos os processos. A mensagem é que todos os dias pelo menos uma melhoria tenha sido feita na empresa. A atenção voltada para melhorias e racionalizações permeia toda a organização.

O melhoramento contínuo oriental difere dos processos de inovação das empresas ocidentais. Estas últimas são pautadas pelos saltos qualitativos pontuais de mudanças de padrão, envolvem um pequeno grupo de concepção, grandes Investimentos e orientado pela tecnologia, ao passo que o Kaizen é um processo de permanente melhoria de padrões com crescimento lento e contínuo, com 
envolvimento e portanto adesão de todos, orientado por atualizações e conjugações de esforços, como representado no quadro:

\begin{tabular}{|c|c|c|}
\hline & KAIZEN & Inovação \\
\hline 1. Efeito & $\begin{array}{l}\text { A longo prazo e } \\
\text { duradouro, porém } \\
\text { monótono }\end{array}$ & $\begin{array}{l}\text { A curto prazo, porém } \\
\text { empolgante }\end{array}$ \\
\hline 2. Ritmo & Pequenos progressos & Grandes progressos \\
\hline 3. Estrutura de tempo & Contínua e incremental & $\begin{array}{l}\text { Intermitente e nāo } \\
\text { incremental }\end{array}$ \\
\hline 4. Mudança & Gradual e constante & Repentina e passageira \\
\hline 5. Envolvimento & Todos & $\begin{array}{l}\text { Poucos "defensores" } \\
\text { selecionados }\end{array}$ \\
\hline 6. Enfoque & $\begin{array}{l}\text { Coletivismo, esforços } \\
\text { em grupo, enfoque } \\
\text { sistêmico }\end{array}$ & $\begin{array}{l}\text { Forte individualismo, } \\
\text { idéias e esforços } \\
\text { individuais }\end{array}$ \\
\hline 7. Método & $\begin{array}{l}\text { Manutenção e } \\
\text { melhoramento }\end{array}$ & Refugo e retrabalho \\
\hline 8. Estímulo & $\begin{array}{l}\text { "Know-how" e } \\
\text { atualizaçōes } \\
\text { convencionais }\end{array}$ & $\begin{array}{l}\text { Avanços tecnológicos, } \\
\text { novas invençōes, novas } \\
\text { teorias }\end{array}$ \\
\hline 9. Exigências práticas & $\begin{array}{l}\text { Exige pouco } \\
\text { investimento; porém } \\
\text { grande esforço para } \\
\text { mantê-lo }\end{array}$ & $\begin{array}{l}\text { Exige grande } \\
\text { investimento, porém } \\
\text { pouco esforço para } \\
\text { mantê.la. }\end{array}$ \\
\hline 10. Orientaçăo do esforço & Pessoas & Tecnologia \\
\hline 11. Critérios de avaliação & $\begin{array}{l}\text { Processo e esforços } \\
\text { por melhores } \\
\text { resultados }\end{array}$ & Resultados por lucros \\
\hline 12. Vantagem & $\begin{array}{l}\text { É útil na economia de } \\
\text { crescimento lento }\end{array}$ & $\begin{array}{l}\text { Adapta-se melhor à } \\
\text { economia de } \\
\text { crescimento rápido }\end{array}$ \\
\hline
\end{tabular}

Figura 4.2: Diferenças entre o Kaizen e a Inovação

Fonte: ( IMAI, 1988, p.21 ) 
O Kaizen imprime a organização uma dinâmica muito receptiva a transformações e assimilações de tecnologias. Novos métodos de trabalho são incorporados de forma menos conflitiva, facilitando o processo de desenvolvimento organizacional.

\section{4- A gestão de recursos humanos}

STERRS et al. ( 1989 ) subdivide os funcionários nas seguintes classificações:

Empregados centrais: São aquelés que constituem o núcleo da empresa, considerados essenciais, cujo destino pessoal confunde-se com o destino da própria organização.

Empregados regulares: São aqueles que pela dedicação e tempo de serviço já estabeleceram uma relação de compromisso com a empresa, sendo que alguns deles aderem ao núcleo central, e outros ainda migram de empresa.

Empregados marginais: São aqueles com baixo nível de comprometimento e alta descartabilidade, mantendo relações frágeis com a organização.

O corpo de empregados centrais e regulares é muito maior na indústria japonesa do que o verificado em outros países. O operário é visto quase como um ativo fixo da empresa. Comparando a indústria brasileira com a indústria japonesa, FLEURY \& FLEURY ( 1997 ) chegam a conclusão demonstrada na figura 4.3. 


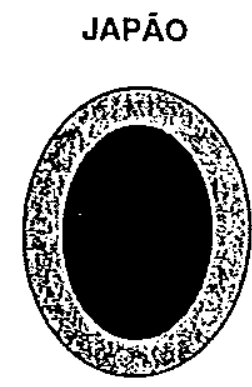

BRASIL

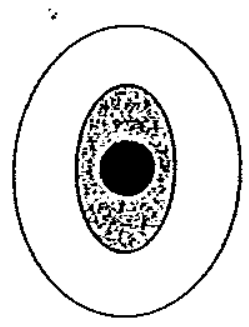

Empregados centrais

圆Empregados regulares

DEmpregados marginais

Figura 4.3- Categorização dos empregados nas empresas brasileiras e japonesas

Fonte: FLEURY \& FLEURY ( 1997, p.148)

Existe um pacto não formal de fidelidade entre a grande empresa japonesa e o funcionário, que transcende flutuações econômicas. Investimentos em capacitação e treinamento são melhores preservados, e a noção de que o progresso da empresa reflete no progresso pessoal é sensível.

O emprego vitalício observado nas grandes organizações facilita a flexibilização da mão de obra, que geralmente tem promoções por senioridade. Não existe impedimentos trabalhistas para o exercício de diversas funções na empresa.

A hora média do setor industrial no Japão é de U\$\$16,91, enquando que o trabalhador brasileiro recebe pela mesma hora U\$\$2,68. (FOLHA DE SÃO PAULO, 1998 ).

Os salários dos operários japoneses são enriquecidos por remuneração de horas extras e bônus especiais, que nem sempre estão associados ao desempenho da empresa, oú seja, mesmo com um resultado operacional não excepcional a empresa paga o bônus. Esta premiação acaba sendo incorporada ao salário. É efetivada 
geralmente semestralmente e corresponde de 30 a $40 \%$ do montante de salário recebido no semestre.

Todos estes beneficios citados, aliados a fatores culturais e organizacionais, fazem da gestão de recursos humanos na indústria japonesa algo bem diferenciado quando comparado com as empresas ocidentais e brasileiras.

O operário é visto como uma despesa viva, que precisa ter a sua utilização maximizada de forma constante. Máquinas são vistas ociosas nas fábricas da Toyota. O mesmo não pode ocorrer com as pessoas. Arranjos industriais são flexibilizados para atender um melhor aproveitamento da força de trabalho.

É interessante a convivência entre aparentes paradoxos, ou a sintese entre os opostos observada. O operário é concebido segundo diretrizes da teoria $\mathrm{Y}$ de McGregor, mas a execução da tarefas nas operações de fábrica são tayloristas. $O$ emprego é vitalício mas a participação do funcionário é intensa e visceral.

\section{5- O nivelamento da produção}

Simplificar os sistemas de produção, para obter-se uma fábrica onde os produtos possam fluir com o mínimo de solavancos possiveis, sem perder em nenhum instante a necessária flexibilidade de produção. Este é o desafio do nivelamento da produção.

A TMC é uma industria discreta de alto volume de produção, mas suas linhas de produção não são dedicadas exclusivamente a fabricação de um modelo de automóveis. Se assim fosse, o atributo principal do STP que é insuperada flexibilidade do sistema e sua notória elasticidade para atender as variaçôes e exigências do mercado estaria maculada. 
Segundo OHNO ( 1997, p 54 ) "O STP foi originalmente concebido para produzir pequenas quantidades de muitos tipos para $o$ ambiente japonês. Consequentemente, com esta base, ele evoluiu para um sistema de produção que pode enfrentar o desafio da diversificação ".

A produção em pequenos lotes mesclados permanentemente é o que confere esta flexibilidade ao chão de fábrica. $\dot{O}$ nivelamento da produção na linha de montagem impede que seja produzido durante um período apenas um modelo de carro. Mesmo se existe demanda para uma certa linha de produção fabricar um modelo A na parte da manhã e um modelo B na parte da tarde, esta medida não é tomada na TMC. Os programadores da produção alternam um produto $\mathrm{A}$ com um produto $\mathrm{B}$, e ambos os modelos saem simultaneamente da linha de produção.

Para ser coerente com a produção nivelada, alguns fundamentos básicos da produção em massa são burlados. Prefere-se lotes pequenos a grandes lotes de produção. Mão de obra flexivel a mão de obra dedicada. Mas a grande diferenciação vem com a troca rápida de ferramenta, fundamento para a produção nivelada.

\section{6- A redução dos tempos de Set- up}

No esforço de reduzir os desperdícios com estoques excedentes, e perseguir a produção apenas das quantidades necessárias no tempo necessário, o lote de produção, tradicionalmente longo, necessitou ser reduzido para atender apenas a necessidade emergencial do cliente interno.

De certa forma, a produção de lotes de produção além da necessidade funciona como um estoque de segurança das operações de fábrica. Quanto maior o estoque intermediários, menores são os riscos se atribuir a produção a falta de algum 
produto final. O raciocínio parece lógico quando os departamentos da empresa são vistos de forma desintegrada, o que não é verdade.

Estoques altos, além de gerar custos de espaço e manutenção física, são utilizados para encobrir possiveis deficiências de planejamento da produção, falhas na manutenção de máquinas, gargalos no processo e ineficiências das mais diversas.

Para a redução do tamanho dos lotes de produção, o tempo de set-up. necessita ser reduzido de forma radical. Não é econômico manter uma máquina produzindo 2 horas se o tempo de troca de ferramenta também durar 2 horas. Portanto, reduzir tempo de set-up é um pressuposto básico para a redução do tamanho dos lotes de produção.

Em 1945 a troca de ferramenta na TMC durava de 2 a 3 horas, sendo que este tempo foi reduzido para 3 minutos em 1971, mediante a troca rápida de ferramenta, TRF.

$\mathrm{O}$ criador do JT afirma que "As trocas rápidas constituem um requisito absoluto para o Sistema Toyota de Produção “ ( OHNO, 1997, p. 108 ). Shingo, um consultor de empresas que auxiliou a TMC no projeto de troca rápida de ferramenta, diz que "o método just in time, que está na essência do Sistema Toyota de Produção, não teria sido desenvolvido, se a'TRF não existisse “( SHINGO, 1996a, p. 308 ).

O método por ele desenvolvido contempla a divisão de tempos entre set-l1p interno e set-up externo, e posterior conversão das operaçôes que causam o tempo de set-llp interno em tempo externo, reduzindo o tempo de parada de produção. Utiliza para agilizar este processo dispositivos de eliminação de ajustes, gabaritos intermediários, dispositivos funcionais de fixação, padronização de funções, operações paralelas e mecanização e motorização.

Este mecanismo pode ser melhor entendido com a figura 4.4 : 


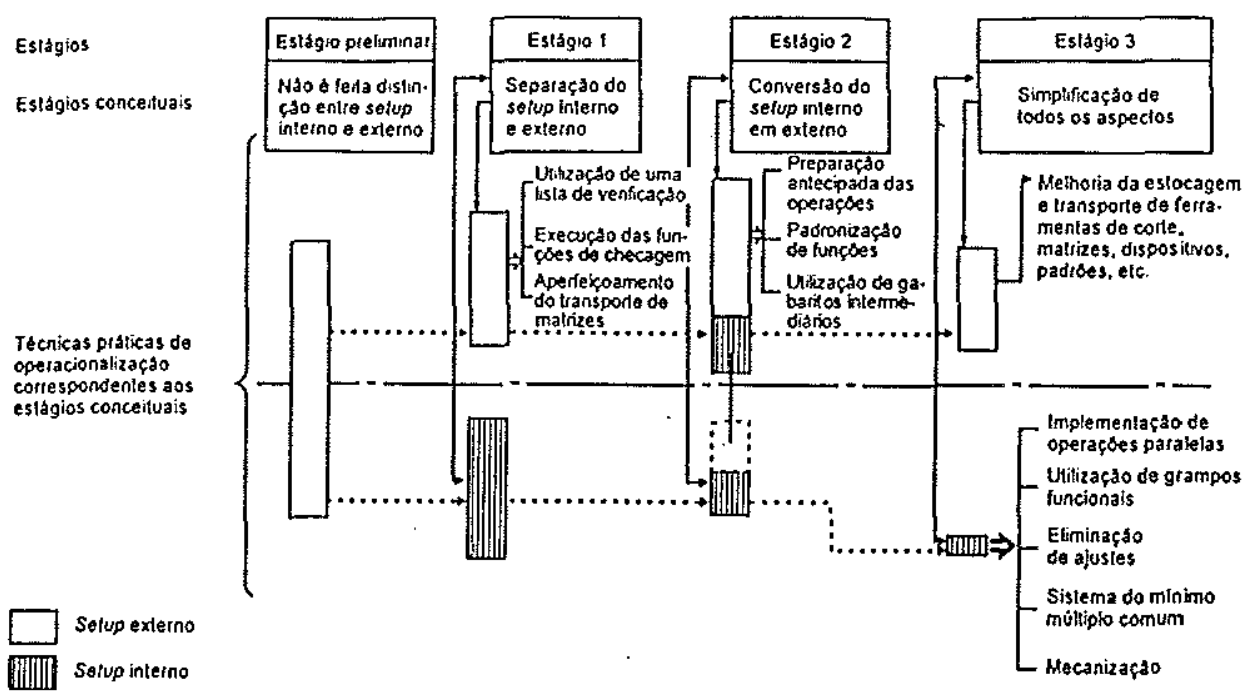

Figura 4.4- Técnicas para redução de Set- $u p$

Fonte: SHINGO ( 1996a, p. 314 )

A redução do tempo de Set-lup, como anteriormente citado, tem sido considerado como fundamental por diversos estudiosos do sistema JIT, em especialShingo, que afirma: " Como criador do TRF, aprecio o fato de que o sistema TRF seja usado em centenas de companhias japonesas e atingiu sucesso considerável na Suiça e nos Estados Unidos. Fico um pouco desalentado, no entanto, com o fato de que, com frequência, artigos a respeito da TRF não mencionem meu nome. Certamente, isso seria o minimo a pedir, por cortesia. Apenas Taiichi Ohno dá crédito 
à minha pessoa de forma consistente ao referir-se ao sistema TRF" ( SHINGO, 1996 b, p. 272 ).

Shingo aproxima-se da TMC por volta de 1955 para aplicar treinamentos como consultor, e desenvolve a melhoria de tempo de set- $u p$ em 1969. Segundo suas próprias anotações, durante este período continuou a trabalhar como consultor em diversas empresas através do Instituto para Melhoria do Gerenciamento, que Shingo fundou em 1959.

O livro publicado no Japão em 1978 por Taiichi Ohno, "O Sistema Toyota de Produção", não faz em nenhum momento menção ao sr. Shingo. E apesar de reconhecer a necessidade da TRF, dedica apenas um breve comentário sobre a troca rápida de ferramentas. Parece que alguns aspectos do sistema $\Pi T$, apesar da importância, tem recebido muito maior divulgação que o próprio criador do sistema a eles empenhava.

\section{7- Operador multifuncional}

Um operador multifuncional é aquele que realiza mais de uma função ao mesmo tempo. Ele é treinado em habilidades que o capacita a exercer diversos tipos de operações, em máquinas e processos diferentes. Isto confere uma grande flexibilidade à força de trabalho para atender as flutuações de demanda, sempre evitadas mas sempre presentes.

Como referido anteriormente, a empresa tem um pacto informal de vitalicidade com seus funcionários. Este fator facilita e favorece a concepção de um operário multifuncional. Esta característica é buscada tanto pela empresa como também pelo funcionário. 
A estrutura trabalhista japonesa não impõe restrições a multi funcionalidade, ao contrário do observado nas principais nações ocidentais e também no Brasil, onde um torneirọ mecânico não pode trabalhar em um setor de galvanoplastia, por exemplo. A própria rigidez nas definiçẽes de cargos e funções funciona como fator que limita o agregar novas qualificações ao operário.

Em um processo de fabricação de engrenagens, um mesmo operário trabalha com 16 máquinas diferentes em lay-out apropriado. " $\mathrm{O}$ trabalhador, atuando como um operário de multipla função, inicialmente apanha uma unidade de engrenagem trazida do processo precedente e a coloca na primeira máquina. No mesmo instante, ele solta outra engrenagem já processada por esta máquina e a coloca num deslizador, através da qual a mesma chega até a próxima máquuina. $\mathrm{O}$ operador, ao se movimentar para segunda máquina, aciona um interruptor localizado entre esta e a primeira para desligar aquela. Ele executa operação similar na segunda máquina e se movimenta até a terceira, acionando o interruptor da-segunda máquina e assim por diante, até ter trabalhado em todas as 16 máquinas, quando retorna ao seu processo inicial. Isto é feito exatamente no tempo de ciclo, talvez em 5 minutos" ( MONDEN, 1984, p. 39 ).

Desta forma, há uma grande redução dos estoques em processo e do tempo de produção, reafirmando o combate sistemático a todo tipo de desperdício.

Esta mudança de concepção na TMC foi lenta e gradativa. Ohno relata que encontrou forte resistência do operariado na conversão de "um operador uma máquina para um sistema de um operador , muitas máquinas em processos diferentes" ( OHNO, 1997, p. 32 ).

O treinamento para a capacitação da multifuncionalidade obedece a um plano de treinamento denominado " rotação de trabalho ". Os operários podem mudar de tarefas até de 2 em 2 horas, conforme grau de dificuldade e fadiga das operações realizadas no processo. 
A fábrica pode contar assim com uma equipe apta para trabalhar em qualquer processo e não dependente de habilidades individuais. A fadiga é prevenida, a visâo de processo é enfatizada e a importância do trabalho em equipe traduz-se em sugestões de melhorias que não envolvem apenas um posto de trabalho. Percebe-se também redução dos acidentes de trabalho e melhoria da qualidade dos produtos:

O tempo disponivel do operário multi funcional é otimizado da melhor maneira possível. O mesmo não se verifica com as máquinas. A prioridade é dada para a máxima utilização do operário, em detrimento da máxima utilização dos equipamentos. É melhor combater a ociosidade humana que a ociosidade dos equipamentos.

O argumento utilizado é econômico. SHINGO (1996a, p. 327 ) fundamenta isto com o seguinte exemplo: " Diz-se que o custo de um trabalhador ocioso por uma hora é de três a cinco vezes maior do que o custo de ter-se uma máquina parada pelo mesmo intervalo de tempo. Como exemplo, considere uma prensa que custa $\$ 60.000$ e é depreciada ao longó de 10 anos. Isso significa $\$ 6000$ por ano ou $\$ 500$ por mês. O custo da mão de obra, incluindo salários e beneficios diversos, provavelmente, será de três a cinco vezes maior. Em resumo, as máquinas parecem mais caras, porque uma grande soma de dinheiro é paga de uma só vez. Mas, quando você faz os cálculos reais, normalmente, o custo do trabalhador é mais alto “

Porisso a Toyota procura fabricar suas próprias máquinas: fáceis de operar, flexíveis, com dispositivos de autonomação e com custos de até $90 \%$ inferiores ás máquinas comerciais disponiveis no mercado.

A produtividade da mão de obra da TMC é 20 a $30 \%$ mais alta que as outras empresas. Em contra partida ela possue de duas a três vezes mais máquinas que as outras empresas. 
Não é prudente utilizar apenas os conceitos tradicionais de custos para obtermos uma vantagem competitiva. Este critério pode inviabilizar investimentos em qualidade e em redução de inventários, conforme GOLDRAT \& FOX ( 1989 ). Porém convém ressaltar que os parâmetros utilizados por Shingo são bastante diferentes daqueles verificados no contexto brasileiro, onde o custo da mão de obra por exemplo é bem inferior ao verificado no Japão, como exposto anteriormente.

\section{8- Controle da Qualidade Total}

A qualidade é tanto um necessidade como uma consequência da produção JIT. SACOMANO ( 1990 ) ressalta que a competitividade tem levado as empresas a revisões periódicas de suas estratégias de qualidade e que, particularmente no Japão, geralmente $70 \%$ do valor do produto é adquirido de fontes externas.

Desta forma, a qualidade na fonte assume papel importante para a efetivação do JIT. A indústria japonesa, no periodo seguinte a segunda guerra mundial, foi auxiliada por Juran, Deming e Feigenbaum para a concepção de um sistema de qualidade conhecido, TQC, articulado pela Union of Japanese Scientists and Engineers, JUSE .

O TQC pode ser definido como " o controle exercido por todas as pessoas para a satisfação das necessidades de todas as pessoas "( CAMPOS, 1992, p. 15 ). Envolve todos os níveis hierárquicos na concepção e condução do controle da qualidade, sendo que a responsabilidade pela qualidade precisa partir da alta gerência, num processo top down. Fazer certo da primeira vez é a frase de efeito que sintetiza os fundamentos da gestão de qualidade, em qualquer atividade da organização, seja uma tarefa administrativa ou produtiva. 
O mesmo autor afirma que "o TQC é baseado em elementos de várias fontes: emprega o método cartesiano, aproveita muito do trabalho de Taylor, utiliza o controle estatístico de processos, cujos fundamentos foram lançados por Shewhart, adota os conceitos sobe o comportamento humano lançados por Maslow e aproveita todo o conhecimento ocidental sobre qualidade, principalmente o trabalho de Juran" (CAMPOS, 1992, p. 13 ).

Os custos de não qualidade são desperdícios que podem ser observados nos custos de materiais em sí, valor agregado de todas as operações que exigem mão de obra e equipamentos anteriores a observação da não conformidade, reprogramações de produção, custos de espera em quarentena, controles, desbalanceamentos, registros de não conformidades, manutenção física etc.

Sem uma produção conforme, ou seja, dentro das especificações do projeto de produto, qualquer esforço de produzir em pequenos lotes assume riscos consideráveis de interrupção da produção devido a uma não conformidade detectada. Na produção JT interrupção na produção pode significar de forma muito mais rápida a interrupção de saída de produtos acabados.

O controle precisa ser exercido com a instrumentalização de índices comparativos. A determinação de padrões de conformidade são essenciais, e o controle precisa ser exercido mediante representações numéricas para comparação com os padrões pré estabelecidos.

O processo, não apenas a operação em sí, é a prioridade também no sistema da qualidade. O estabelecimento de prioridades para a melhoria contínua das atividades de qualidade é parte constituinte do TQC. Métodos de identificação de problemas, como a curva de Pareto e os gráficos de Ishikawa, estabelecimento de prioridades, metodologias de resolução de problemas, técnicas de criatividade como o "brain storming", e mecanismos de implantaçâo como os ciclos PDCAs ( plan, do, check, action ) são ferramentas incorporadas pelo TQC. 
Os seguintes aspectos são importantes no TQC, segundo CORRÊA \& GIANESI (1993): Controle do processo, visibilidade da qualidade, disciplina da qualidade, paralisação das linhas, correção dos próprios erros, inspeção $100 \%$, lotes pequenos, organização e limpeza da fábrica, excesso de capacidade e verificação diária dos equipamentos. Percebe-se que o envolvimento dos operários é requerido em muitos destes aspectos.

De fato, na fábrica a função do controle de qualidade é devolvido para quem fabrica o produto. A responsabilidade é recolocada sobre os operários de produção, e não mais sobre os iluminados departamentos de controle de qualidade. Estes passam a ter uma função maior de treinamento, capacitação, prevenção e melhorias do que inspeções e controles em sí.

Como dito, os dispositivos de autonomação e baka yoke contribuem para o controle do processo e restrição da produção de não conformes.

Percebe-se um enfoque abrangente, sistêmico, sinergético e envolvente no controle de qualidade.

\section{9-Lay out apropriados}

A disposição das máquinas no chão de fábrica precisa ser revista para a assimilação da produção JT. A configuração buscada nos estudos de lay-out. é aquela marcada pela simplificação, que permite, conforme SCHOMBERGER ( 1987 ) os produtos fluirem como água, assemelhando-se as plantas de indústrias com fluxo de produção contínuo.

O lay-out na produção JIT favorece o processo de produção, que precisa ser compreendido não como uma sequência de operações de produção. SHINGO (1996a, 
p. 29 ) distingue estes fatores da seguinte forma: "Produção constitui uma rede de processos e operações, fenômenos que se posicionam ao longo de eixos que se cruzam. Em melhorias de produção, deverá ser dada prioridade máxima para os fenômenos de processo ".

Racionalizar lay-out na produção JIT é muito mais que melhorar as operações de produção ou organizar os postos de fabricação mais ergonometricamente. Ultrapassa os limites de estudos de tempos e métodos, remetendo-a ao estudo de processos industriais. Operações e processos são analisados em eixos distintos. Muito mais sensiveis são as repercussões de melhorias de processos quando comparado com as melhorias de operações, porisso precisam ser buscadas.

Para atender os pequenos lotes de produção, a redução de atividades que não agregam valor como transportes e esperas, favorecer a ocupação dos operadores multifuncionais em detrimento da ocupação de máquinas e focar o processo prioritariamente no processo de fabricação, o lay-out no sistema JIT assume a configuração de uma célula de produção geralmente em forma de U.

Uma célula de produção é um agrupamento de máquinas por processo de fabricação. O operário multifuncional se movimenta de equipamento para equipamento, contrariando princípios tayloristas de divisão rigida de trabalho e princípios fordistas de movimentação de produtos sem a movimentação de operários, como verificado em linhas de produção tradicionais.

Apesar do alto custo da mão de obra o operador tem grande movimentação entre máquinas nas células de produção. Mesmo assim a produtividade da mão de obra é alta devido aos dispositivos de autonomação, dispositivos baka yoke a prova de erros de funcionários e o balanceamento dinâmico da produção.

A atenção primordial ao processo no lay-out celular permite trabalhar com tamanho de lotes reduzidos e principalmente que o chão de fábrica assimile 
frequentes necessidades de flexibilização e balanceamento da produçâo diante de flutuações de demanda.

Uma célula de produção individual é combatida na TMC. Busca-se uma integração entre as diversas células, evitando com isto estoques entre células interligadas e atividades de transporte entre as células. Esta integração facilita a realocação de operários entre as diversas células decorrentes de flutuações de produção: Esta facilidade é muito dificil de ser observada em linhas de produção tradicionais com operários especialistas dedicados. A figura 4.5 ilustra o fato:

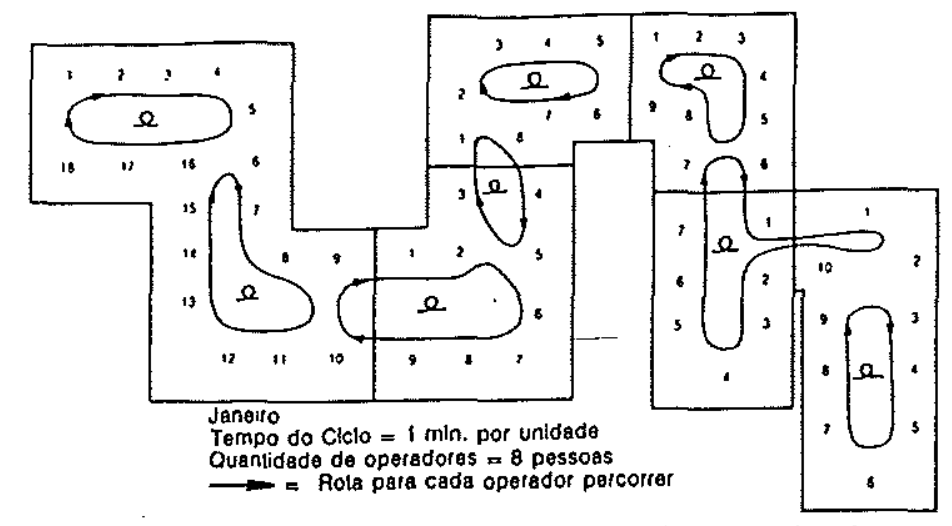

Alocsçto de operaçóes entre operadores em Janelro

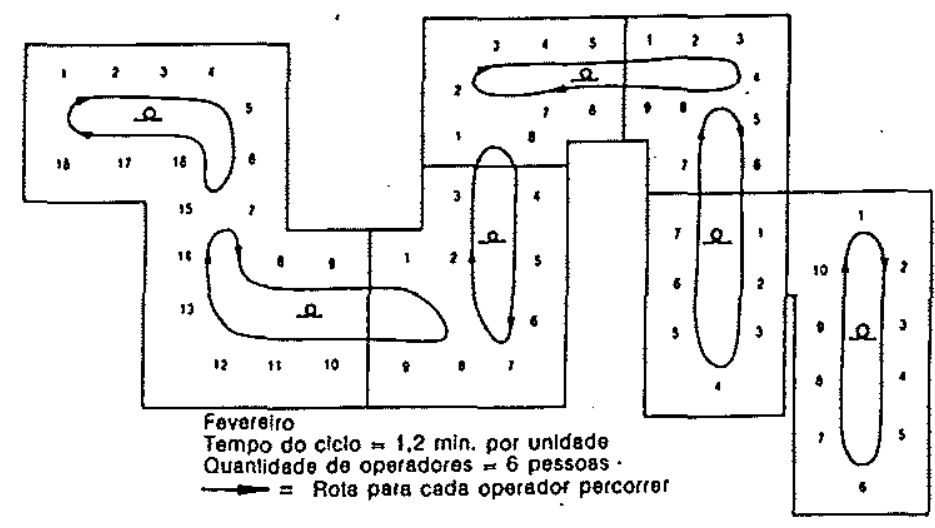

Alocaçso de operaçóses entre operadores om Feverelro

Figura 4.5: Flexibilidade de configurações de linhas produção.

Fonte: MONDEN (1984, p. 61 ) 
A tecnologia de grupo, ou seja, a concepção do projeto visando enquadrar peças com processo de fabricação similares aquelas já existentes, integra o projeto às células de fabricação, auxiliando na padronização de operações das células e otimizando os recursos de fabricação.

\subsection{0- Sincronização da produção}

Conforma afirma OHNO ( 1997 ) o sistema de produção da TMC foi desenvolvido para atender pequenas quantidades de muitos tipos diferentes, atendendo necessidades de diversidade solicitadas pelo mercado. Isto requer uma sincronia entre os diversos setores envolvidos no negócio.

A sincronia de produção pode ser analisada em dois aspectos: Sincronia interna à fábrica, restrita ao ambiente interno da organização e a sincronia externa, mais relacionada com o ambiente externo, envolvendo mais proximamente redes de fornecedores e mercado.

\subsection{1- Sincronização externa}

A relação entre as cadeias de fornecedores precisa ser bem estabelecida e respeitada. O ambiente corporativista criado pelos zaibatsu e a integração horizontal entre empresas de certa forma facilitam esta vinculação entre empresas, criando relacionamentos à longo prazo, reduzindo custos de frequentes negociaçôes comercias, controles, etc. Esta vinculação e senso de compromisso são importantes para que a cadeia de fornecimento de pequenas quantidades com frequências menores seja respeitada como um código de honra entre as empresas. 
No sistema JIT os estoques são vistos como desperdícios, portanto precisam ser combatidos. Assim, a quantidade de matéria prima e componentes comprados em estoques é reduzida ao mínimo possível. Esta responsabilidade de fabricação ou reposição é repassada ao fornecedor, que por suas vez repassa o seu estoque ao subfornecedor. Esta sincronia é importante para manter o sistema JT funcionando estruturalmente como uma rede ou cadeia de produção intimamente dependentes.

Um automóvel tem aproximadamente 10.000 itens. Se na cadeia de produção apenas 1 item estiver indisponivel, toda a demanda das 9.999 peças também fica comprometida. A produção precisa fluir como agua também entre os fornecedores e sub-fornecedores. O mesmo rigor dos fundamentos JT intra organizacionais necessitam ser observados nas relações entre os fornecedores.

Alguns fatores de risco merecem destaques: Não é o bastante a produtividade apenas das cadeias produtivas. A atividade de logistica também é envolvida nesta rede de fornecimento JIT. Meios de transporte confiáveis e seguros e políticas alfandegárias facilitadoras, se não observados, podem comprometer a eficiência da produção.

O risco de paralizações da produção por meio de greves de funcionários em algum ponto da cadeia é um grande fator de instabilização de todo o processo. $\mathrm{O}$ enxugamente de estoques sistematicamente em todas os relacionamentos inter fabris expõe as empresas a todos estes riscos de forma mais acentuada.

Se nas atividades internas à empresa o controle é mais facilmente exercido, as instabilidades externas exigem uma contingência bem maior e mais complexa de fatores para o exercício do controle. Quanto maior a inoperabilidade e credibilidade de organismos normativos e controladores externos, maiores são os riscos de ruptura da cadeia JIT.

"Os fornecedores no Japão estâo normalmente associados com um único cliente e são tratados como uma divisão do comprador "(LUBBEN, 1989, p.179).

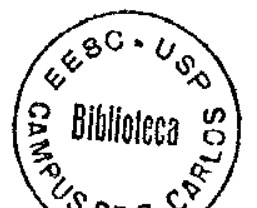


Contratos de longo prazo são estabelecidos, proporcionando maior segurança e horizonte financeiro ao fornecedor.

A confiabilidade nestes contratos a longo prazo são fundamentais. Uma vez estabelecido o relacionamento, a comunicação entre ambos é feito de forma muito mais intensa, compartilhando-se inclusive sistemas de gestão empresarial. Custos de negociações são praticamente cortados a zero.

Estas situações conjunturais e culturais observados no Japão são muito rarefeitamente percebidas no Brasil, tornando muito mais dificil a sincronia necessária entre diversas organizações da cadeia produtiva. Empresários do mesmo setor de atuação queixam-se frequentemente da falta de empenho e unidade dentro das próprias associações patronais. As câmaras setoriais apresentam resultados opacos, sofrendo influência político partidária circunstanciais, restringindo seu alcance a políticas limitadas sem adesão conjuntural. $\mathrm{O}$ ambiente empresarial individualista e de restrita visão de curto prazo, talvez escolado pelos constantes e surpreendentes planos de estabilização econômica, apenas ultimamente apresenta sinalizaçôes de alianças estratégicas forçados pela cömpetitividade e fusões internacionais.

\subsection{2- Sincronização interna}

Sincronização interna é aquela observada entre os processos internos à empresa. Mais que uma organização configurada em função do processo, uma vez estabelecido o melhor fluxo entre as atividades de produção, a operacionalização diária precisa manifestar uma sincronia dinâmica.

Isto seria muito simples de acontecer se toda a fábrica trabalhasse com apenas um tipo de produto, pois teriamos uma linha de montagem dedicada, apenas com variações de quantidades e detalhes de acabamento, sem flutuações de produtos. 
Montar fábricas dedicadas é um processo que exige altos investimentos de alto risco, pois os mercados estão em constante mutação, como já observado.

A sincronia de produção é dirigida pela necessidade de flexibilidade operacional, que surge decorrente da adequação rápida as flutuações observadas no mercado e da otimização da aplicação dos recursos fisico/financeiros.

Na TMC uma planta fabril atende diversos modelos diferentes de automóveis. A mesma linha de produção processa simultaneamente modelos diferentes de produtos. É a chamada produção nivelada. Estabelecer uma sincronia de fabricação em meio a esta diversidade é um desafio considerável.

Recursos materiais precisam estar disponíveis quando necessário, em pequenos lotes, para atender a mudança constante de mix. Trocas de ferramentas precisam ser realizadas de forma muito mais rápida e diversas vezes ao dia. A multifuncionalidade do operário é requerida também nestes nivelamentos de produção. $\mathrm{O}$ corpo de princípios do $\Pi \mathrm{T}$ atuam conjuntamente para se atingir os detalhamentos individuais expostos neste capitulo.

Existe na TMC um Planejamento da produção trimestral e mensal. O Plano Mestre de produção determina as quantidades médias diárias para cada tipo de carro, segundo o Planejamento Mensal. A flexibilidade e sincronização da produção mostram-se presentes já neste nível de organização da produção, mas fundamentalmente é sentida nas adaptações diárias de produção. A agilidade do chão de fábrica em mudar o mix de produção assemelha-se a um ajuste fino e rápido às . imprevisiveis mas sempre presentes flutuações de demanda.

A sincronização é uma cadeia integrada de informações, materiais e recursos de produção. Plano Mestre, relação com fornecedores e flexibilidade de produção são componentes que se inter relacionam para proporcionar uma sincronização de produção adequada para atingir a produção JIT. 


\subsection{1- A inversão do fluxo de produção}

Se muitos principios da produção JIT não são originais, uma exceção a esta afirmação é a inversão do fluxo de produção. Esta foi uma grande inovação do STP.

O fluxo dos modelos tradicionais de produção inicia-se nas primeiras atividades de manufatura. O plano mestre de produção é transformado em programas diários, e as primeiras máquinas que começam a processar as ordens de fabricação são geralmente as primeiras operações representadas nas cartas de processo ou fluxograma de fabricação. Desta forma os produtos semi manufaturados vão sendo transportados de máquina em máquina, da primeira até a última operação de produção. Os lotes de produção seguem um fluxo que inicia-se com a retirada de estoques de matéria prima, a progressão deste material pelas operações seguintes de fabricação até a chegada no estoque de produto acabado. Os materiais são “ empurrados " da primeira operação, aquela sequencialmente mais próxima do estoque de matéria prima, para as operações posteriores.

A resposta a uma necessidade de mercado neste arranjo tradicional é percebidamente longo. Faz-se necessário processar todas as operações de fabricação até que o pedido começe a entrar no almoxarifado de produto acabado.

No STP ocorre uma inversão deste fluxo. Uma vez comandado uma necessidade de produção pelo Plano Mestre, a progressão do produto faz-se de forma oposta ao verificado no modelos tradicionais de produção. A primeira operação a ser comandada é aquela mais próxima do almoxarifado de produto acabado, e não aquela mais próxima do depósito de matéria prima. A última operação da carta de processo é a que primeiro vai ser realizada. Em sequência as operações anteriores começam a ser acionadas, "puxando a produção ". A primeira operação é aquela que agrega atributos e entrega o produto final elaborado. A última operação è a retirada do almoxarifado de matéria prima. 
Um pré requisito para viabilizar o sistema de " puxar " a produção é a criação de estoques de semi elaborados. É preciso ter algum estoque em processo para o ciclo de fabricação ter início e continuidade. Estes estoques de semi-elaborados precisam ser rigidamente controlados e mantidos nos niveis mais baixos possiveis.

Ohno inspirou-se nos modelos de abastecimento dos supermercados americanos para a criação destes pontos de convergência de semi-elaborados. Diz ele que " um supermercado é onde um cliente pode obter o que é necessário, no momento que é necessário, na quantidade necessária... os operadores dos supermercados, portanto, devem garantir que os clientes possam comprar o que precisem em qualquer momento" (OHNO, 1997, p. 45 ).

Ohno enxergou o JT dentro dos supermercados, e adaptou o mesmo meçanismo para dentro da fábrica. A retirada de produtos das " prateleiras " gerava necessidade de reposição pelos--outros centros de produção anteriores. A operacionalização destes sequenciamentos fica a cargo dos próprios operários mediante a utilização de cartões, denominados de Kanban, que fazem a ligação entre as diversas operações. O sistema Kanban será detalhadamente visto no capítulo seguinte.

A perspicácia em adaptar procedimentos de área tão diversa, como um supermercado, ao ambiente industrial é algo inusitado. Ohno realizava benchmarking intuitivamente. Cultivava uma personalidade observadora e inovadora. 


\section{CAPÍTULO 5: \\ O GERENCIAMENTO VISUAL DA PRODUÇÃO}

O objetivo deste capítulo é gerar uma visão mais ampla sobre o gerenciamento visual da produção, contribuindo para o entendimento de como esta ferramenta fundamental do $\Pi \mathrm{T}$ consegue alcançar de forma simples maior controle e eficiência sobre o processo de administração da produção, agindo sobre o fluxos de informações e materiais.

\section{1- A administração da produção}

A administração visual da produção tem seu campo de ação mais especificamente no chão de fábrica, auxiliando de forma inovadora na administração da produção.

A administração da produção, "é a atividade pela qual os recursos, fluindo dentro de um sistema definido, são reunidos e transformados de uma forma controlada, a fim de agregar valor, de acordo com os objetivos empresariais " ( MONKS, 1987, p. 4).

ROCHA ( 1995, p. 5 ) conceitua a administração da produção como sendo " a parte da admininistração que comanda o processo produtivo, pela utilização dos meios de produção e dos processos administrativos, buscando elevação da produtividade “. 
Outros autores ampliam o conceito, afirmando que " é o campo de estudos dos conceitos e técnicas aplicáveis à tomada de decisões na função de Produção "(MOREIRA, 1993, p. 3 ).

A administração da produção ocorre mais especificamente no ambiente de chão de fábrica. Preocupa-se em como melhor planejar, organizar, dirigir e controlar as atividades relativas a fabricação e demais atividades associadas. Faz parte do desdobramento do Planejamento Estratégico da empresa, situando-se no nível mais operacional. Assim, administrar a produção não é um conjunto de atividades autônomas, mas sim sincronizadas com uma série hierárquica de planos empresarias que ocorrem simultaneamente.

A busca da otimização nas utilizaçôes dos recursos é um objetivo continuado, bem como a eficiência nos processos mais próximos de transformação. Nas organizações industriais, a administração da produção está mais relacionada com as atividades fins da empresa.

Interessante notar a influência do chão de fábrica na determinação de movimentos na história da Administração como ciência. Taylor conceituou a administração científica primeiro no nível de piso de fábrica, e depois expandiu os conceitos de divisão de trabalho e padronização de tarefas para os setores administrativos. Foi com as experiências realizadas em grupos de trabalho operacionais que Mayo também conceituou o movimento das relações humanas, cuja aplicabilidade extrapola o nivel operacional apenas. $O$ mesmo pode ser verificado na administração japonesa.

\section{2- Os fluxos de informações e materiais}


A produção envolve dois grandes fluxos para serem administrados: O fluxo de materiais e o fluxo de informações. A harmonia entre estes fluxos é essencial para manter a produção JIT. Eles estão em constante interaçâo, influenciando nos resultados operacionais e na eficiência da fabricação, conforme PLOSSL ( 1993 ).

O processo de fabricação é um processo de transformações físicas. Matérias primas sofrem transformações que agregam valor e são disponibilizadas aos clientes mediante resultados financeiros favoráveis. O fluxo de materiais e produtos está na essência do processo de fabricação sendo, como visto, uma preocupação constante da produção JIT.

A disponibilidade de materiais na execução da fabricação é essencial para o sucesso operacional. O planejamento de materiais é realizado mediante uma grande interface com o planejamento de capacidade da fábrica. Estas informações são integradas pelo Plano Mestre de fabricação. Apesar do planejamento antecipado de necessidades, o processo de execução traz com frequência componentes surpresas. $\mathrm{O}$ fluxo de materiais nestas horas precisa ser ágil o suficiente para minimizar prejuizos operacionais.

O fluxo de informações é de uma complexidade maior, pois envolve maior número de variáveis. De certa forma a coordenação de informações no planejamento operacional é bem hierarquizada, como pode ser observado na figura 5.1. 


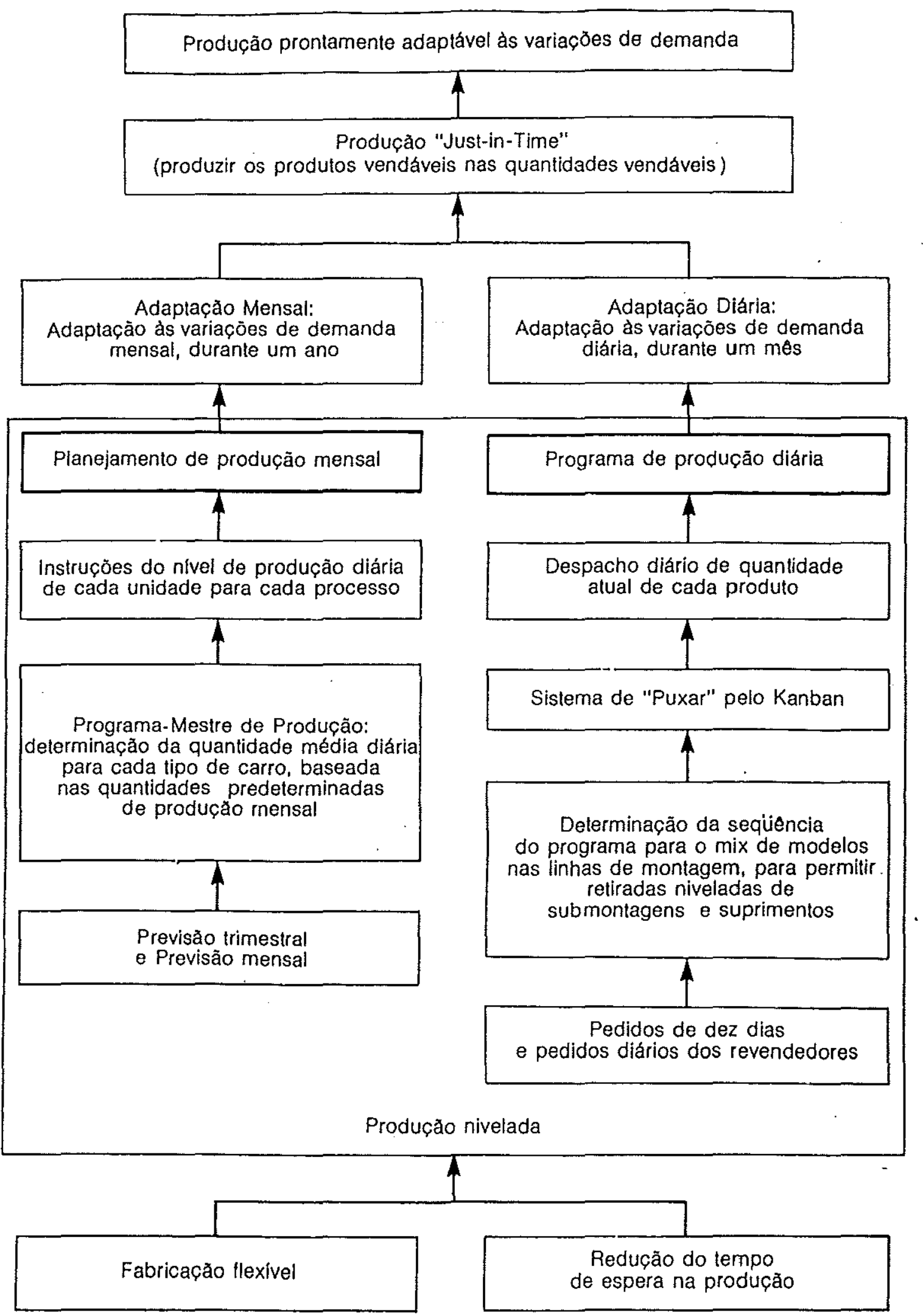

Figura 5.1: Informações e hierarquizações do planejamento operacional na TMC

Fonte: MONDEN ( 1984 p. 32) 
Conforme observa PLOSSL ( 1993 ), esta integração de planos envolve informações relativas a diversos fornecedores, operações dentro da própria companhia e entre os clientes da organização.

Dificuldades maiores começam a surgir quando as informações processadas à priori, geralmente com o auxilio de sistemas de gestão integrada, inicializam o processo de fabricação. A partir deste instante tanto o fluxo de informações como o fluxo de materiais acontecem simultaneamente em tempo real.

O sistema de informação precisa ser ágil o suficiente para proporcionar feedbacks rapidamente enquanto a produção está se processando. A captação de informações no chão de fábrica é complexa. Estas informações precisam estar disponiveis aos interessados para que as correções de curso necessárias sejam efetuadas de forma segura.

Um sistema eficiente de informação e controle do chão de fábrica precisa coletar os dados na produção, transformá-los em informações que possam gerar atitudes administrativas e disponibilizar estas informações aos reais interessados em tempo de oferecer oportunidade de intervenção no processo de fabricação em curso.

Uma falha em algum estágio de processamento da informação pode comprometer o desempenho de toda uma linha de produção. Se algumas falhas são sentidas apenas localmente, isto pode não acontecer quando o sistema de informação, manual ou automatizado, falhar. O tempo não é passivel de armazenamento ou retrabalho.

Embora mais complexo, o fluxo de informações é muito mais rápido que o fluxo de materiais. Lead Time de compras e produção são muito mais longos que o processamento da informação. A comparação que PLOSSL ( 1993 ) utiliza é bastante ilustrativa. A velocidade do fluxo de informações é comparada a um relâmpago, e o fluxo de materias mais se assemelha ao movimento das águas de um rio. 


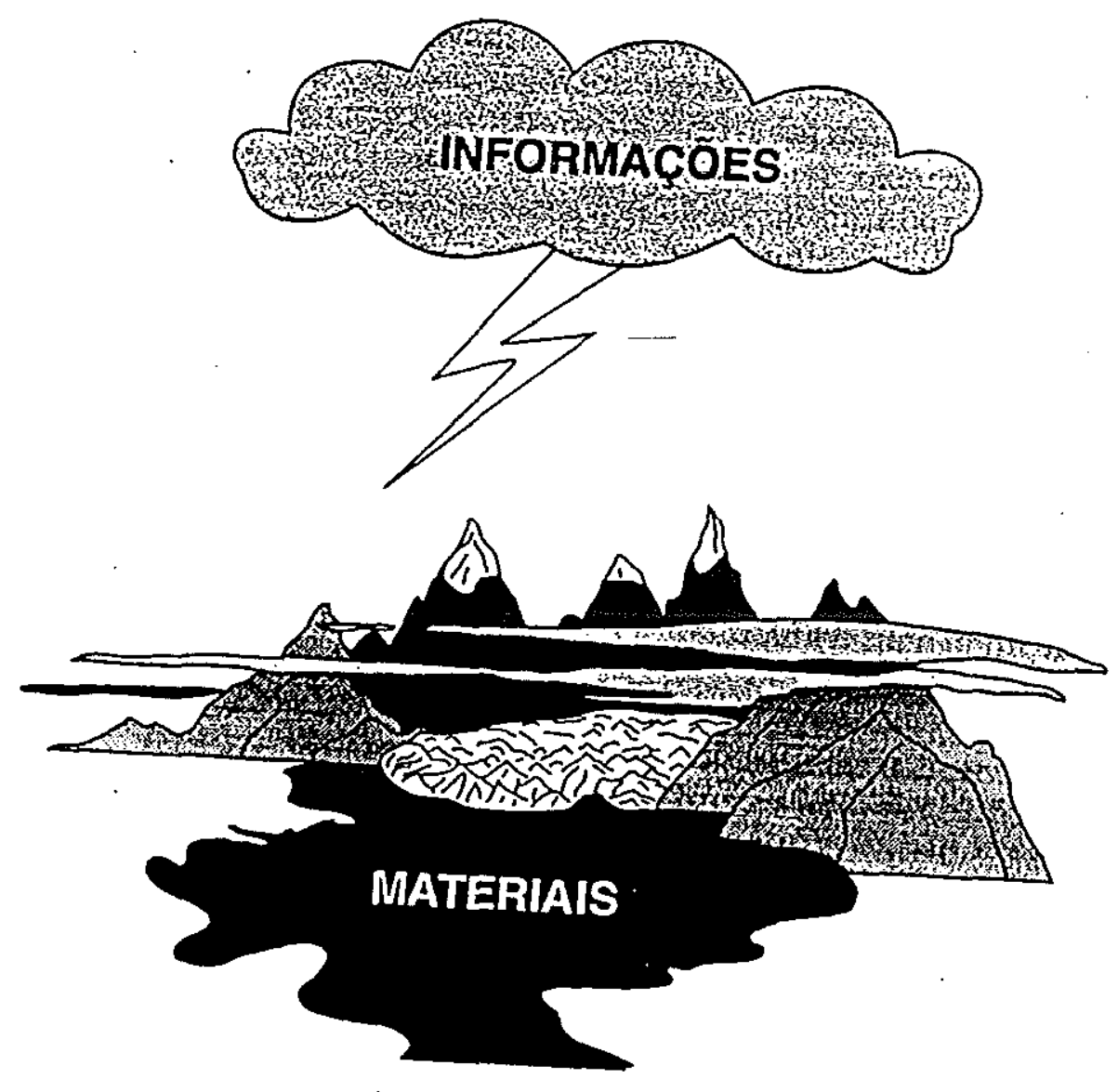

Figura 5.2: Fluxo de informação e materiais.

Fonte: PLOSSL ( 1993, p. 10)

O mesmo autor afirma que " em operações de fabricação, todos os beneficios serão diretamente proporcionais à velocidade do fluxo de materiais e de informações “ (PLOSSL, 1993, p. 18).

O criador do sistema JIT trata a informação como um recurso que também precisa ser administrado dentro da filosofia JIT . Afirma que " A produção JIT da Toyota é uma forma de entregar à linha de produção exatamente o que ela precisa quando é preciso. Este método não requer estoques extras. De modo semelhante, 
queremos informações apenas quando elas são necessárias. As informações enviadas a produção devem ser exatamente programadas no tempo" (OHNO, 1997, p. 65).

Quanto mais próximo da execução da tarefa, mais complexo é estabelecer uma sincronia entre o fluxo de materias e o fluxo de informações que permita intervenç̧ões operacionais otimizadora de recursos. Esta sinergia é de relevante importância para a administração da produção.

5.3- Utilização de recursos computacionais para o controle de fluxo

A manipulação de dados é muito grande no chão de fábrica. Os dados precisam ser agrupados e processados para serem então apresentados como uma informação, que pode ser entendida como uma compilação de um conjunto de dados. A informação, uma vez gerada, e para ter razão de existência como nos alerta OHNO ( 1997 ), precisa ser útil para gerar uma ação administrativa. Ver figura 5.3.

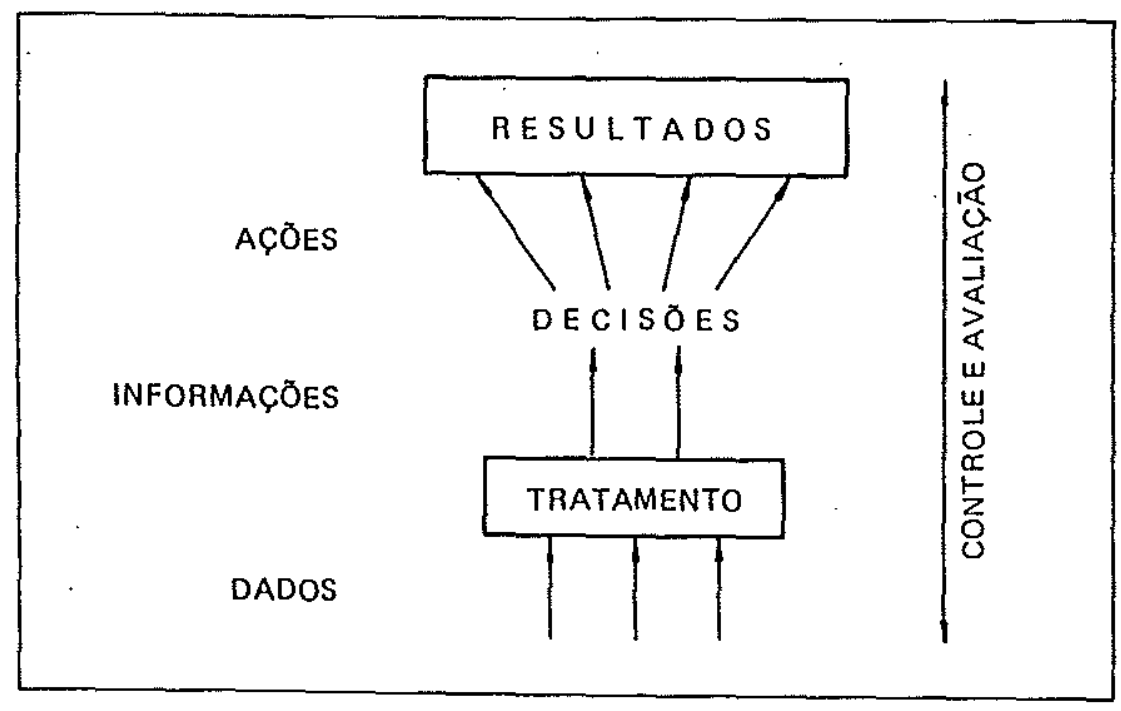

Figura 5.3- Sistema de Informação Gerencial

Fonte: OLIVEIRA ( 1988, p. 44) 
Aparentemente nada mais próprio que utilizar os computadores para a execução também desta tarefa de processamento da informação. Para os níveis de planejamento táticos, obviamente a TMC também utiliza os computadores, semelhantemente a organização das informações que nos proporciona os sistemas de gestão de empresas tipo MRP I e MRP II.

MRPs são sistemas de administração da produção, SAP, que utilizam computadores de médio e grande porte, com o objetivo de " permitir o cumprimento dos prazos de entrega dos pedidos dos clientes com mínima formação de estoques, planejando as compras e a produção de ítens componentes para que ocorram apenas nos momentos e nas quantidades necessárias, nem mais nem menos, nem antes nem depois. "(CORRÊA \& GIANESI, 1993, p. 104 ).

A automação do planejamento que envolve o Planejamento da Produção, o Plano Mestre, o Planejamento de Necessidades de Materiais, o Planejamento das Necessidades de Capacidade, a interface com Materiais e Compras é extremamente facilitado pelo uso de computadores. A lógica de processamento não é a mesma no sistema JTT e nos sistemas MRPs; mas existe certa concordância que ambas compartilham alguns objetivos comuns e também que ambas utilizam recursos computacionais.

A diferenciação ocorre na profusão de utilização e no foco do agente de mudança. O MRP, bem como a conceituação do CIM, foca a máquina e a tecnologia como agente principal de produtividade. A filosofia ЛT, ao contrário, tem seu ponto de mudança no fator humano e em técnicas mais próximas das tarefas.

A própria estratégia de automação do chão de fábrica das indústrias japonesas é diferente. O conceito de autonomação, como visto anteriormente, não prescinde do elemento humano. Já o conceito de fábricas escuras buscadas por alguns industriais no ocidente, isto é, indústrias que trabalham sem a necessidade do homem a tal ponto 
de poderem funcionar com as luzes apagadas, também tornam o homem um recurso a ser apagado.

A relutância com a utilização em profusão dos computadores é percebido na declaração : " Na Toyota não rejeitamos o computador, porque ele é essencial para planejar os procedimentos de sincronização da produção e calcular o número de peças necessárias diariamente. Usamos o computador livremente, como uma ferramenta, e tentamos não ser manipulados por ele. Mas rejeitamos a desumanização causada pelos computadores e a forma com que podem conduzir a custos mais altos. (OHNO, 1997, p. 65).

Os sistemas computadorizados encontram dificuldades maiores para proceder a ajustes inesperados, sempre evitados pelos niveis superiores de planejamentos, mas sempre presentes operacionalmente. $O$ gerenciamento visual da produção instrumentaliza-se como uma ferramenta para facilitar estes ajustes finos requeridos pelos executores das tarefas.

\section{4- O gerenciamento visual da produção}

O gerenciamento visual da produção são todos os mecanismos utilizados para tornar visível ou aparente os fatores relevantes para uma adequada administração da produção no nível operacional.

Ohno é quem usa a denominação de gerenciamento pela visão. Ele afirma que " esta idéia se aplica às máquinas e à linha assim como à organização das mercadorias e ferramentas, inventários, circulação de Kanban, procedimentos de trabalho padrão e assim por diante. Nas linhas de produção em que se usa o Sistema Toyota de Produção, o controle visual, ou gerenciamento pela visão, é obrigatório “ (OHNO, 1997, p. 136 ). 
O intuito do gerenciamento pela visão é tornar aparente o que está oculto. Tornar público o que está restrito. Tudo o que pode ser coletivizado é assim realizado pelas técnicas do gerenciamento pela visão. Estoques em processo, índices de qualidade, paradas de linhas de produção, interrupções de máquinas, padronizações de trabalho e até o próprio sentimento do funcionário são visualmente reconhecidos por todos.

Isto é concebido para facilitar o processo de tomada de decisão pelos funcionários mais próximos à execução das tarefas. Se a Administração Científica dividiu a realização do trabalho em procedimentos específicos e estratificados, a administração japonesa subverte este conceito. Além de multi funcional, é requerido do operador funções não só de execução, mas também de planejamento de suas próximas atividades e o controle de suas próprias ações.

Devido a proximidade das tarefas e a possibilidade de interferência operacional, a rapidez da informação é fundamental, bem como a formatação da linguagem, que precisá ser clara e de fácil interpretação pelos funcionários. Informações condensadas em forma de relatórios neste nível são de pouca utilidade, seja pelo caráter restrito de análise, seja pelo tempo demandado para colher, processar e disponibilizar as informações.

No gerenciamento visual as informações estão disponiveis a todos os operários. Existe portanto uma descentralização da informação e consequentemente do poder. É claro que estas informações são fundamentais para uma adequada operacionalização dos processos, e não mais do que isto.

Informações democratizadas implicam tanto em maiores responsabilidades na execução das tarefas, bem como maior controle social exercida pelo grupo.

O gerenciamento visual facilita sobremodo o processo de administração da produção. Recursos são melhor identificados e alocados, facilitando o processo de 
tomada de decisão que influenciarão nos resultados operacionais.. A atuação do gerenciamento é no fornecimento de informações no nível mais próximo da liberação e controle de materiais, indicando condições de qualidade e quantidade dos produtos semi elaborados, disponibilidade do equipamento e estado de espírito do operário

Permite melhor planejamento a curtíssimo prazo, favorecendo interferências quase em tempo real pelos interpretadores das informações. Fornece meios efetivos de controle individual e coletivo além de melhor organizar o ambiente de produção.

O modo como o gerenciamento visual pode apresentar-se é bastante variado. O STP consagrou as seguintes técnicas:

\subsection{1- O Sistema Kanban}

O sistema Kanban foi idealizado por Ohno, e é o principal instrumento para operacionalizar o STP. A inspiração para o desenvolvimento do Sistema Kanban vem dos supermercados, onde os usuários retiram somente o que necessitam, no tempo e quantidade adequada. A reposição é feita de tal forma que dificilmente existe falta de um produto nas gôndolas. Através dele tornou-se possivel:

* A produção em pequenos lotes de forma controlada pelo operário

* A produção sincronizada pela reposição sistemática de pequenos estoques

* A inversão do fluxo de produção ou " puxar " a produção

Kanban em japonês significa anotação visível ou cartão. O sistema Kanban pode ser entendido como o sistema de gerenciamento por cartões, e é de fato uma inovação na administração da produção próximo ao nível da tarefa. 
AOKI ( 1990 ) afirma que o "Kanbam é reconhecidamente eficaz para fazer o ajuste fino da programação da produção, ao mesmo tempo que reduz o tempo e o esforço requerido para as comunicações e negociações entre as unidades produtivas, dispensando a intervenção hierárquica dos departamentos de programação e suprimentos".

O Kanban torna visível os estoques em processo. Ele agrega os produtos semi elaborados em pequenos lotes. Estes lotes são agrupados fisicamente dentro de um container, que pode ser uma caixa por exemplo. A unidade de controle passa então a ser este agrupamento. Cada pequeno lote recebe um cartão de identificação, onde constam diversas informaçôes, tais como a quantidade de peças que constam em cada lote, o local de utilização do semi elaborado, o roteiro de circulação do cartão etc.

A movimentação destes cartões constituem a dinâmica do sistema Kanban. Estes cartões transitam entre o container e os paineis. A quantidade de cartões nos paineis fornecem informações de produção para os processos anteriores, tanto em termos do que fazer, quantidades requeridas ( que são fixas e constam no cartão ) e prioridades segundo necessidades em tempo real.

Como o STP procura trabalhar com o mínimo de estoques possivel, o dimensionamento dos lotes de peças semi elaboradas que serão gerenciados pelo cartões é de muita importância. Deste dimensionamento controlado é que depende o giro de produtos na produção e consequentemente o Lead Time de produção.

O número de cartões é fixo, como também é rígido a quantidade de semi elaborados que cada cartão gerencia. Assim o estoque em processo é mantido sob controle, não permitindo a produção adiantar pedidos ou produzir além do solicitado pelos cartôes.

A circulação dos cartões é previamente determinada. Eles fazem a ligação pré estabelecida de uma seção para outra seção. Os cartões tem circulação restrita entre 
os elos da produção, não permitindo que um acúmulo de inventário venha a ocorrer apenas em um ponto do encadeamento de produção. O sistema Kanbann, além do gerenciamento visual, proporciona rítmo e encadeamento à produção, fornecendo informações na medida necessária para que decisões sejam tomadas .

Caso haja necessidade de interferência na administração do número de cartões, consequentemente da quantidade de estoques em processo, o administrador do sistema pode de forma rápida aumentar ou diminuir a quantidade de cartões circulantes. Esta retirada deliberada do número de cartões é utilizada para que o sistema de produção apresente seus pontos frágeis, e que medidas corretivas e preventivas sejam tomadas para termos um processo de fabricação sempre ágil e responsivo a flutuações.

Uma vez compreendido a dinâmica de funcionamento do sistema, o próprio operário reage as informações disponibilizadas. Informações de prioridades de produção e quantidades a serem produzidas não precisam ser passadas via hierarquia superior. O painel fornece todos estes indicativos. O próprio operário interfere no processo de planejamento de suas próprias atividades. Agregar atividades de planejamento e organização do próprio serviço é contraditório com os princípios tayloristas de divisão de trabalho.

O sistema é muito facilmente passivel de auditoria. Todos os estoques circulantes no chão de fábrica necessitam de identificação via cartões. O que não está identificado são materiais produzidos sem a permissão do cartão. Devido a simplicidade, o controle de funcionamento pode ser exercido tanto por cargos hierárquicos superiores como também pelos operacionais. O controle é socializado e a pressão e exercida pelo próprio grupo.

A TMC consagrou o sistema Kanban que utiliza dois tipos diferentes de cartões: um cartão de produção e um cartão de transporte ou requisição. O cartão de produção é o inicializador do processo de reposição de peças acabadas dos 
containers. O cartão de transporte faz a ligação entre os diversos setores de produção, sendo responsável pela movimentação de materiais na fábrica.

MONDEN ( 1984 ) cita algumas regras de utilização do sistema Kanban. São elas:

$1^{\circ} \mathrm{O}$ processo subsequente deve retirar, no processo precedente, os produtos necessários nas quantidades necessárias e no ponto necessário.

$2^{\circ} \mathrm{O}$ processo precedente deve produzir seus produtos nas quantidades requisitadas pelo processo subsequente.

$3^{\circ}$ Produtos com defeitos não devem ser enviados ao processo subsequente.

$4^{\circ} \mathrm{O}$ número de Kanbans deve ser minimizado.

$5^{\circ}$ Kanban é usado para adaptar pequenas flutuações na demanda.

É muito utilizado também o sistema Kanban de cartão único. $\dot{E}$ um sistema mais simplificado que o Kanban de dois cartões, onde apenas um tipo de cartão transmite as informações de produção. Operações fabrís mais próximas fisicamente fazem a opção por este tipo de configuração de Kanban. No Brasil ele é bem mais utilizado que o sistema tradicional da Toyota de dois cartões.

A abrangência do sistema Kanban não se limita apenas às operações internas à empresa, mas atende as interligações entre empresas. Os fornecedores são acionados por um sistema Kanban externo, fazendo suas entregas segundo as necessidades reais visualizadas pelos quadros de Kanban da Toyota. A rede de logística ganha contorno fora dos limites da fábrica, conferindo grande agilidade a montadora. Este repasse de responsabilidades tem gerado algumas dificuldades para a TMC. Algum elo da cadeia 
produtiva vai precisar absorver os estoques reguladores... Fornecedores diretos da Toyota, regidos por contratos a longo prazo, tem flutuações cónsideráveis no seu plano mestre, com variações de até $20 \%$ do plano mensal planejado.

Reconhecendo algumas limitações, OHNO ( 1997 ) alerta para a necessidade de proximidade de fabricantes mais próximos à planta da TMC, bem como no necessário auxílio da Engenharia Industrial da Toyota às empresas fornecedoras para uma melhor adequação ao STP.

Maiores detalhes do mecanismo de funcionamento, as diversas formas de dimensionar o tamanho dos lotes e as variações do sistema Kanban podem ser observadas em diversas publicações já consagradas e reproduzidas com fartura.

\subsection{2- ANDON}

Andon são quadros colocados em pontos visualmente privilegiados que fornecem um diagnóstico em tempo real das condições de operacionalização de processos chaves da produção. Estes quadros são geralmente acompanhados de lâmpadas ou sinalizadores luminosos, acionados pelos operários ou por meio de dispositivos eletrônicos. Estes sinalizadores representam o que está ocorrendo na linha de montagem.

Segundo Ohno, " quando as operações estão normais, a luz verde está ligada. Quando um operário deseja ajustar alguma coisa na linha e solicita ajuda, ele acende uma luz amarela. Se uma parada na linha for necessária para corrigir um problema, a luz vermelha é acesa. Para eliminar completamente as anormalidades, os operários não devem ter receio de parar a linha “( OHNO, 1997, p. 129 ). 
os esforços são dirigidos para uma rápida solução dos problemas que esteja causando a paralização. Assim, supervisores, mecânicos e colegas de linha são rapidamente envolvidos para o restabelecimento da normalidade.

Nos quadros Andon fica muito nítido o gerenciamento e controle visual: Existe a possibilidade real de interferência no andamento da linha de produção. $O$ bloqueio da fabricação é acessivel ao operário. Ele não precisa recorrer a métodos escusos para paralisar a linha, como em movimentos contestatórios organizados. Legaliza-se e até estimula-se a interferência do trabalhador, com o chamamento de não ter temor em acionar os dispositivos de parada de linha.

Toda informação alimentada pelo indivíduo é irradiada em tempo real para o sistema social próximo. A ação individual imediatamente provoca reações sociais não restrita ao agente causador.

Se por um lado é dado liberdade de interferência, por outro o controle sobre o individuo aparece de forma muito intensa. $\mathrm{O}$ atraso na produção é tornado público. Todos dirigem a atenção ao painel visual controlador. A pressão social para não ser o causador de atrasos é muito grande. A mente do trabalhador pode trabalhar com um novo fator de pressão para não ser ele o causador de interrupções. Então o cuidado com a manutenção e disponibilização dos equipamentos dos quais ele é usuário deve ser redobrado.

Estes fatores de pressão social são amplificados pela cultura japonesa. Povo tipicamente retraído e massificado em seus usos e costumes, estar em evidência por problemas causados é por demais constrangedor. O enquadramento dentro de especificações é buscado de forma muito mais intensa pelo trabalhador japonês do que seria por um trabalhador ocidental.

Os quadros de Andon revelam-se excelentes indicativos da instrumentalidade do gerenciamento visual da produção, fornecendo informações que permitem 
interferência sobre parâmetros da produçâo a curto prazo e em tempo real, mobilização inter funcional para a resolução de problemas, melhor organização e manutenção dos instrumentos de produção para evitar que o posto de trabalho seja o causador da parada de linha e principalmente um poderoso controlador social das relações homem $X$ máquina $X$ homem.

\subsection{3- Quadros de situação pessoal}

São quadros disponíveis em seções de trabalho com a identificação de cada funcionário do grupo. No início do expediente o próprio funcionário sinaliza mediante uma ficha colorida o seu estado de humor no dia. Se ele está bem, harmônico e sem problemas pessoais, ele por exemplo fixa uma ficha verde na frente de seu nome. Se por outro lado ele está passando por algum tipo de dificuldade familiar, financeira ou de qualquer outra ordem ele pode sinalizar com uma ficha de outra cor. Assim, todos procedem no início do expediente, proporcionando aos colegas de equipe um indicativo externo de como cada um está se sentindo no presente dia.

O objetivo expresso deste tipo de quadro é para servir de norteamento das relações pessoais no dia. Se alguém está com problemas pessoais, a exemplo do quadro Andon, os outros colegas de seção podem tentar ajudá-lo de alguma forma, ou mesmo demonstrar mais flexibilidade no relacionamento pessoal naquele dia. Pode ser que os próprios colegas de trabalho precisarão socorrer o colega em dificuldade, se desdobrando mais intensamente para que a equipe não seja prejudicada nos índices de produtividade. A abordagem da chefia imediata sobre o subordinado precisa ser conforme o estado de espírito expresso pelo funcionário.

Assim como as máquinas precisam estar plenamente disponiveis, sendo alvo de manutenções preventivas e preditivas para serem acionadas conforme a necessidade, da mesma forma espera-se a disponibilidade plena do fator humano. 
Porém, diferentemente da máquina, o recurso homem é um ser com alma e sentimentos, impossíveis de serem plenamente mantidos sob controle.

A utilização dos paineis para tentar " mensurar " o estado de espírito pesșoal, se fornece indicativos para um melhor trabalho em equipe, é uma subserviência da pessoalidade e liberdade em favor do controle social e da produtividade. É uma sujeição da intimidade à coletividade.

A atitude em sí do operário de expor a sua intimidade para a organização é de alcance muito profundo. Revela uma confiança muito grande na estrutura de recursos humanos da empresa, em sua capacidade de absorver favoravelmente as inquietações pessoais. Esta relação não se dá em um divã, mas no chão de fábrica. Não é restrita a um ambiente terapêutico, mas é escancarada para ciência de todos os colegas de trabalho, e por todos que visualizam o quadro. É a submissão da alma em favor da eficiência e da produtividade. "Existe atualmente a psicomanipulação. Ou seja, não só a mais valia é extraida do trabalho; há a perda do seu ser em detrimento do bom desempenho profissional, tendo como única finalidade a rentabilidade " (TRAGTENBERG, 1989, p. 26).

\subsection{4- CARTAS DE PROCESSO}

Diz Ohno que na Toyota o " controle visual da produção é estabelecido integralmente. As folhas de produção são afixadas em local bem visivel em cada estação de trabalho "( OHNO, 1997, p. 41 ). As folhas de trabalho padrão são consideradas um meio de controle visual.

Muito mais que um documento emitido por um setor dissociado da produção, próprio para se engavetado, como ocorre em grande parte das fábricas, a folha de trabalho padrão, ou folhas de produção são elevadas a um status de muita importância 
dentro do sistema JIT. Elas são o maior instrumento para o combate ao desperdício de tempo e materiais. Através delas lay-outs são remodelados, processos são modificados, ferramentas são melhoradas, a logística de materiais é otimizada, métodos de produção sâo re elaborados.

Estas folhas de produção trazem informações simples, mas fundamentais para o operário. Os três elementos básicos constantes nestes documentos sâo o tempo de ciclo, a sequência do trabalho ou rotinas de operação padrão e o estoque padrão.

OHNO ( 1997 ) explica que o tempo de ciclo é o tempo alocado para fazer uma peça ou unidade. Isso é determinado pela quantidade da produção, ou seja, a quantidade necessária e o tempo da operação. O tempo de ciclo é calculado dividindo-se as horas de operação pela quantidade necessária por dia.

A sequência do trabalho ou rotinas de operação é a sequência de ações que cada operador deve executar dentro de um dado tempo de ciclo. Estas informações revelam a rotina que o operador multifuncional precisará obedecer durante o periodo, sendo que esta configuração de trabalho pode alterar-se, segundo mudanças no mix de produção planejado.

A quantidade de material em estoque, como preza a filosofia JIT, precisa ser a mínima possivel e visualmente identificáveis. Este inventário não pode ser confundido com estoque de segurança, mas uma necessidade de materiais inerentes ao processo de fabricação, necessárias em rotinas de operação com fluxo inverso a sequência de processamento ou o resfriamento de uma unidade em produção até a mesma poder prosseguir no processo de fabricação.

O responsável por gerar a folha de processo é o supervisor da produção. Ele próprio executa a sequência de operações e verifica a executabilidade das mesmas, antes de ensiná-la aos operários. 
Ohno diz que a tarefa do supervisor de área, chefe de seção ou supervisor de equipe é treinar trabalhadores." Eu sempre disse que deveria levar apenas três dias para treinar novos operários nos procedimentos adequados de trabalho. Quando as instruções estão claras sobre a sequência e os movimentos básicos, os operários aprendem rapidamente a evitar refazer um trabalho ou a produzir peças defeituosas" ( OHNO, 1997, p.42). 


\section{CAPÍTULO 6:}

\section{TRABALHO EM GRUPOS}

O trabalho em grupo e o envolvimento dos funcionários é uma constante no JT. O objetivo deste capítulo é proporcionar um aprofundamento da conceituação do trabalho em grupos na produção, referenciando-se a duas vertentes mais influenciadora: a visão sócio técnica e a visão da administração japonesa.

6.1- O trabalho em grupo na administração científica.

O homem é concebido pela administração japonesa como um ser com potencialidades positivas a serem lapidadas em favor da organização, contrariando os pressupostos da Administração Científica. O homem é focado como o agente principal nos processos de avalancagem de produtividade. Criar condições para que esta potencialidade se traduza em atitudes concretas, transformar a energia potencial em energia cinética, elevando o valor do homem como ser humano, é uma das missões dos orgãos de gestão de recursos humanos.

Taylor concebia o homem como um ser limitado, que apresentaria melhor produtividade dedicando se a atividades restritas e individualmente. A restrição das atividades levou o operador de fábrica a especialização em determinada tarefa. 
O trabalho solitário, ou em um grupo restrito e controlado, era visto como uma prevenção à contaminação pela indolência natural do homem. Segundo o autor quando os homens trabalham em grupo existe um nivelamento por baixo, ou seja, quem determina os níveis de produção é o operário mais mediocre. Por isso ele baixou uma ordem somente permitindo o trabalho de mais de quatro funcionários juntos com autorização expressa do superintendente da fábrica, e por tempo limitado.

O esforço de otimizar apenas a tarefa consagra o pressuposto de se considerar um homem para cada posto de trabalho. Quando mais ele é adestrado, melhor vai ser seu rendimento final.

Os beneficios da especialização da tarefa traduziram-se em um grande salto nos índices de produtividade. Com o mercado apresentando pressão de demanda maior que a oferta, a produção em massa apoiada em princípios tayloristas/fordistas espraiou-se pelo ambiente industrial da época.

Alguns dos efeitos colaterais desta concepção taylorista foi a alienação do operário do trabalho e uma visão reducionista da função do homem nos processos de fabricação como apenas um agente mecânico.

Conforme COLENCI \& GUERRINI ( 1999, p.16)), “ a reorganização das tarefas em processos ocorreu com a necessidade de buscar modelos estruturais mais flexíveis, onde a responsabilidade passou a ser uma atribuição das equipes de trabalho em detrimento das funções dos gerentes ".

Assim, novas necessidades organizacionais surgiram pressionadas pela flexibilidade de produção. O papel do grupo de trabalho, da participação e valorização do homem na organização, com início de abordagem ingênua no movimento das Relações Humanas, toma nova formatação no sistema socio técnico e no sistema JIT, trazendo uma concepçâo evolutiva dos modelos anteriores. Estes atributos são importantes dentro desta nova filosofia organizacional. 


\section{2- O sistema sócio técnico}

Vimos que o sistema JT consolidou-se no Japão durante os anos 80. Porém anterior a este periodo um grupo de pesquisadores europeus fundamentaram uma corrente de pensamento em que um ponto importante é o trabalho em grupos.

$\mathrm{Na}$ década de 50 os efeitos colaterais do Taylorismo/Fordismo sobre a força de trabalho manifestavam-se na forma de alto absenteísmo, doenças profissionais, e rotatividade da mão de obra. A evolução de sistemas automatizados, em especial máquinas ferramentas fixas, acrescentavam novos vetores à natureza do trabalho do homem na produção.

Este quadro social fabril leva alguns pesquisadores ingleses e suecos a novas proposições na forma de organizar o trabalho e a produção, com o objetivo mais voltado para a realização pessoal do operário em suas atividades diárias. Surge assim a sociotécnica.

Os grupos de trabalho são ingredientes fundamentais nesta corrente de pensamento. A maior realização do homem, pressupõe-se, irá acontecer nesta interação social entre os trabalhadores que fazem parte do grupo, e que-ao mesmo tempo responde as necessidades técnicas requeridas ( como a resolução de problemas complexos ).

O grupo assume " a responsabilidade completa pela produção de um produto ou linha de produtos. Este grupo não deve possuir tarefas fixas predeterminadas para cada componente e a supervisão não deve interferir na maneira pela qual o grupo se auto atribui tarefas. Cabe a supervisão a função de servir como elo de ligação entre cada grupo e o seu meio externo “ (HERBST, 1974, p. 58 ). 
A concepção de trabalho em grupo na sociotécnica é diferente da abordagem das relações humanas e comportamentais. Ao grupo, geralmente com 8 a 15 pessoas, é atribuido funções e responsabilidades de grande autonomia sob o ponto de vista da administração cientifica. O grupo tem a capacidade de se auto configurar, sem a interferência da supervisão. $O$ modo de melhor realizar a tarefa não segue necessariamente um documento externo, existindo flexibilidade na execução das operações.

Estes grupos são denominados semi-autônomos porque, "nem todas as decisões passam a ser tomadas pelo grupo. Em particular, os aspectos estratégicos relativos à definição de tecnologias, políticas de produção, vendas e finanças permanecem como atribuições de gerentes e diretores" ( MAX, 1998, p. 27 ).

"O conceito de grupos autônomos de trabalho é diferente de enriquecimento do trabalho, mas é sim um capítulo importante na história da evolução das condiçôes de trabalho, cujo surgimento foi fortemente influenciado pelo movimento sindical europeu" ( MAXIMIANO, 1995, p. 333 ).

Conforme EMERY \& TRIST ( 1972 ) a natureza de trabalho requerida dos componentes dos grupos semi autônomos precisa corresponder aos seguintes anseios:

- As atividades desempenhadas em um grupo devem constituir um significado completo de per sí.

- Deve existir alguma autonomia dentro do grupo para o estabelecimento de padrões ao mesmo tempo em que o feed back dos resultados deve ser enviados ao grupo.

- Deve haver algum controle sobre as tarefas desempenhadas nas fronteiras entre os grupos.

- Devem ser previstos canais de comunicação adequados para que trabalhadores sem experiência possam ser incorporados a grupo sem grandes pressões no início. 
- A definição de líderes /supervisores deve ser sancionada pelos trabalhadores.

Percebe-se uma nova filosofia de trabalho nestes principios, que favorece o potencial humano de realização, auto gestão e composições sociais. A estrutura organizacional da fábrica parece seguir um fluxo de baixo para cima, com os próprios operários referendando seus lideres de grupo. Existe uma rotação nesta função de liderança. "Os resultados da empresa passariam a ser obtidos menos por coerção e mais por indução de comportamentos estimulados por um dado projeto organizacional coerente" ( MAX, 1998, p. 27 ).

\subsection{1- A fábrica da Volvo em Uddevalla.}

A Volvo é uma empresa sueca notória pelas inovações na organização do trabalho. Já no início da década de 70 , pressionados pela monotonia e desgaste da linha de montagem, a Volvo criou uma nova fábrica em Kalmar sem a linha de montagem tradicional. Esta nova configuração em galpões hexagonais, onde os veículos eram montados em estações, utilizou os grupos semi autônomos para gerenciar cada mini linha de produção.

Uma fábrica mais inovadora na organização do trabalho foi projetado no final da década de 80. Esta planta localizada em Uddevalla foi concebida com apoio sindical, e norteou-se em privilegiar a qualidade de produção e a qualidade de vida do operário. Voltada para a montagem do produto final, possuia aproximadamente 500 funcionários.

O fundamento de sua organização foi a autonomia e o trabalho em grupo. A linha de montagem tradicional foi abolida para que o ritmo da produção não fosse imposto, mas controlado pelos próprios funcionários. Os grupos semi autônomos 
atuavam cada um em uma doca. Os ciclos de montagem para cada operador foram estimados em 2,5 horas para quebrar a monotonia do trabalho, o que significa que o operador iria repetir o ciclo aproximadamente 3 vezes durante o dia.

Os grupos eram compostos de aproximadamente 10 componentes, sendo o líder eleito pelo próprio grupo. A capacidade de produção de cada doca foi estabelecido mediante estudos de tempos e métodos, não sendo posteriormente utilizados estas informações para controles externos ao grupo. As metas semanais de produção eram negociados e os resultados eram exigidos em termos de quantidade e qualidade de cada doca.

A remuneração era função tanto do acúmulo das habilidades individuais como também do desempenho do grupo, com diferenciações salariais individuais. O lider recebia um adicional de $10 \%$ de salário.

Esta planta da Volvo foi inaugurada em 1989, e encerrou operações em 1992. Alguns fatores externos são apresentados como fatores de contribuição do fechamento, tais como a produção de produtos customizados, o ciclo longo de produtos, a estrutura organizacional em que a fábrica estava submissa e o relacionamento com os fornecedores. ELLEGARD et al. ( 1994 ), afirmam que apesar da elevação sistemática dos indicadores tradicionais de produtividade e qualidade no setor automotivo - medidos entre 89 e 92 - em Uddevalla, estes índices sempre.estiveram abaixo dos niveis atingidos pelas fábricas japonesas.

A Volvo reativou a planta de Uddevalla em 1995, em joint venture com a TRW ( inglesa), para a produção de carros de maior valor agregado, mantendo o sistema de trabalho que a consagrou. Pesquisadores aguardam os resultados e adequações desta que foi a mais notória experiência empresarial com grupos semi autônomos. 
Por outro lado, o êxito dos grupos de trabalhos semi autônomos é proclamado por outra fábrica da Volvo em Gotemburgo, que se apresenta em 1997 como uma das melhores fábricas do grupo, tendo iniciado o programa de desenvolvimento baseado em grupos semi autônomos em 1990, conforme JONSON ( 1998 ). Alguns pesquisadores julgam que "não há outra forma melhor de mobilizar os recursos humanos para alcançar niveis de flexibilidade e qualidade com custos comparáveis do que aquelas advindas dos grupos semi autônomos" (DANKBAAR, 1998, p.1 ).

\section{3- O Trabalho em Grupo no sistema JIT}

"O trabalho em equipe é tudo " ( OHNO, 1997, p. 42 ). Esta frase resume a importância do trabalho em grupo na produção JT.

Em suas analogias com práticas esportivas, OHNO ( 1997 ) compara o trabalho em equipe de fábrica com uma equipe de remo, onde todos precisam remar corretamente e sincronizadamente. Não basta a presença de 2 ou 3 remadores excepcionais, o que faz a diferença é a distribuição igual da força. Da mesma forma, o que importa na fábrica é a quantidade de produtos completos no final da linha como um todo. O espirito de equipe é reforçado para que os membros dos grupos de trabalho se auxiliem mutuamente, segundo surgirem as necessidades.

Também compara o trabalho em equipe como uma corrida de revezamento, onde a área de passagem do bastão é fundamental. Se existir uma boa performance nos momentos do revezamento, o tempo total final pode ser melhor que os tempos individuais dos quatro corredores . É o conceito de sinergia enfatizado por COVEY aplicado no chão de fábrica.

FLEURY \& FLEURY ( 1997, p. 45 ) afirma que nas empresas japonesas," o uso e desenvolvimento de conhecimento são fortemente objetivados e associados a 
estratégia competitiva da empresa através da organização das chamadas Atividades de Pequenos Grupos", refocando o trabalho em grupo não apenas como um fator motivacional, mas principalmente como um enfoque estratégico para a empresa.

Certamente a concepção de trabalho em equipe que Ohno idealiza é muito diferente dos grupos semi autônomos da sócio técnica. Estes tem a sua origem influenciada pelos movimentos sindicais europeus. O trabalho é repensado segundo análises influenciada pela crítica marxista de polaridade de classes e exploração da mais valia. Já os grupos de trabalho do sistema JIT são concebidos e mantidos pelos superiores hierárquicos, ideologicamente comprometidos com a função de maximização do lucro, via discurso de competitividade, produtividade e redução de custos. A natureza da concepção do trabalho em grupo nascem de vertentes diferentes.

Isto porém não significa que existam diferenças substanciais na aplicação das técnicas de produtividade e diferenciação na concepção de trabalho operário dentro da vertente idealizada pelos dominadores econômicos. Com comentado, o taylorismo, norteado também pela maximização do lucro, tem uma concepção muito mais mecanicista, desintegradora e reducionista do ser humano quando comparado com a concepção do homem na filosofia ЛT.

Os grupos de trabalho no $\Pi \mathrm{T}$ assemelham-se com as técnicas de enriquecimento do trabalho proposto por HERZBERG et al. ( 1959 ) aplicados não a uma pessoa isoladamente, mas a um grupo como unidade de transformação. Novas tarefas são incorporadas ao grupo de trabalho, ampliando o horizonte de desafios, responsabilidades, decisões e reconhecimento profissional. A figura 6.1 ilustra este enriquecimento do trabalho. 


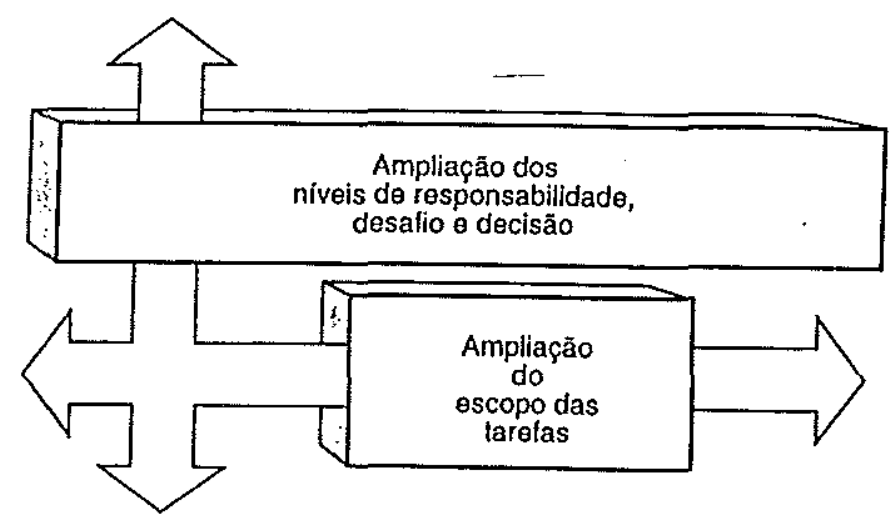

Figura 6.1: Princípios básicos de enriquecimento do trabalho.

Fonte: MAXIMIANO ( 1995, p. 331 )

MAXIMIANO ( 1995, p.332) enumera algumas destas técnicas:

- Rodízio de cargos contíguos, como forma de promover entre os ocupantes o conhecimento da importância do seu cargo dentro do fluxo de trabalho.

- Treinamento e desenvolvimento para aprimorar inclusive aptidões não diretamente relacionadas com o cargo.

- Participação em comissões, equipes de projeto e outros grupos semelhantes.

- Premiação por aumento de produtividade ou participação em processos de racionalização e melhoria da qualidade. 
Analisando estas técnicas, é bastante perceptível a semelhança com os grupos de CCQs e os grupos multifuncionais de produção.

\subsection{1- Os Círculos de Controle de Qualidade, CCQ.}

ESCRIVÃO FILHO ( 1987 , p. 2 ) define CCQ como " pequenos grupos de trabalhadores da mesma área de trabalho, treinados na mesma filosofia de colaboração no trabalho e técnicas simples de resolução de problemas que se reúnem voluntariamente para identificar, analisar, propor soluções e, às vezes, tomar parte na implantação das soluções, com a finalidade de melhorar a qualidade de seu trabalho, tendo como orientação os objetivos empresariais de aumento de produtividade e redução de custos“.

Os. objetivos dos grupos de CCQs relacionam-se com reduções de custos, melhoria de qualidade, segurança do trabalhador e melhoria de processos. Também são efeitos colaterais benignos o aumento da motivação, uma melhor comunicação e harmonia entre os participantes e a maior valorização do operário.

A participação voluntária e o apoio da administração são considerados fatores fundamentais para o sucesso do CCQ. A participação voluntária significa que quem participa dos grupos assim o faz não por coerção, mas de livre vontade. Estes funcionários separam um tempo geralmente fora do horário de trabalho para se dedicarem a melhorar os resultados da organização por desejo próprio. Teoricamente e formalmente ninguém é forçado a nada.

Já o apoio da administração é fundamental para dar credibilidade a estrutura dos grupos de CCQs. A alta direção da empresa precisa apoiar e prestigiar formalmente estas iniciativas. Isto significa participar dos processos de apresentação de idéias e premiações. Assim, por consequência, é requerido da média gerência maior 
adesão e sustentação dos grupos de $\mathrm{CCQ}$, pois esta iniciativa é acompanhada atentamente pela hierarquia formal da empresa.

Existiu no ocidente uma panacéia muito grande sobre os círculos de controle de qualidade, principalmente na década de 80 . Os grupos eram tidos como os grandes impulsionadores do- sistema ЛT, e houve uma reprodução muito acentuada de implantações em empresas ocidentais. A grande maioria destas iniciativas revelaramse ineficientes. Os grupos de CCQs no Japão são consequencias de uma filosofia de recursos humanos e dos princípios de Kaizen, o que revela uma amplitude muito mais dilatada do que tomar decisões pragmáticas de promover reuniões de qualidade, como se isto por sí só traria os benefícios do sistema JTT.

$\mathrm{O}$ adesionismo voluntário e o discreto apoio da administração ocultam, segundo alguns estudiosos, uma iniciativa de melhor induzir o trabalhador a cooperar no esquema de trabalho. Salerno ( 1985, p.32-2) afirma que "o movimento de CCQ, ao procurar negar a existência de interesses divergentes entre os atores da organização (trabalhadores, gerência, patronato ), ao tentar enfraquecer as formas de organização autônoma dos trabalhadores ( não controlados pela empresa), ao procurar manipular recompensas simbólicas ( prêmios, trofeus, medalhas, etc ) aproxima-se de uma postura integrativa ", tornando-se um instrumento de cooptação . Esta visão mais crítica é também compartilhada por TRAGTENBERG ( 1989, p. 33 ) quando afirma que algumas atividades de grupo " não passam de panacéias de interiorização de repressão, pela sedução de sua aparência modernizante, em proveito da desmobilização política como uma exigência formativa “.

6.3.2- Grupos na produção e participação do operário.

Como citado anteriormente, o espírito de equipe é intencionalmente fomentado na produção JT. Q trabalho todo na produção é concebido para-ser um 
trabalho de equipe. Os operários são treinados em multi funções para atender ao requisito flexibilidade.

A flexibilidade de produção significa rapidez para reconfigurações do ambiente de fábrica para atender alterações no mix de produção. As equipes de trabalho reconfiguram-se graças a multifuncionalidade do operário. A flexibilidade de alocação dos trabalhadores aos postos de trabalho é uma das preocupações básicas e é a partir dai que surge o seu conceito de trabalho em grupos. A TRF para atender estas alterações também exige um sincronizado trabalho em equipe. Conforme MAX (1998 ), era uma função básica de Ohno zelar pela flexibilidade de alocação dos trabalhadores aos postos de trabalho.

A mobilização na resolução de-problemas sinalizados pelos quadros de andon revelam também o envolvimento conjunto dos funcionários de chão de fábrica parauma rápida solução da interrupção da linha de produção.

$\mathrm{O}$ equilibrio entré a disciplina e a criatividade é refletido no trabalho em grupos no JT. A disciplina é notória no esforço de cumprimento dos tempos esperados de produção, pois persiste a visão tayloristas de existir uma única forma melhor de realizar cada tarefa. Isto, no entanto, não inibe a criatividade do grupo em buscar sempre melhorar o padrão que já existe e auxiliar outros colegas em situações de comprometimento dos indicadores de produtividade.

Tentando equacionar o envolvimento dos indivíduos nestes ativos grupos de trabalho, $\operatorname{MAX}(1998$, p.33 ) afirma que há “ a busca de um modelo coerente entre estratégia, estrutura, organização e gestão de recursos humanos “.

Já foi ressaltado anteriormente a visão estratégica dos grupos de trabalho, a concepção positiva do homem pelos administradores japoneses, a gestão de recursos humanos e as promoções por senioridade. Mesmo avaliando a conjugação de diversos fatores motivacionais, é surpreendente o envolvimento do trabalhador 
japonês nos trabalhos em grupos e nas respostas afirmativas de envolvimento pessoal quando solicitado pela organização.

As motivações para o envolvimento pessoal em esquemas de sugestões de melhorias, listados por uma entidade de classe chamada JAPAN HUMAN RELATIONS ASSOCIATION, JHRA , (1997) chegam a ser ingênuas, tais como:

"O sistema de sugestões, antes de tudo, constrói o moral e auto respeito dos funcionários. Mostra-lhes que são membros importantes da família empresarial, com idéias dignas de serem levadas em consideração. A empresa beneficia-se da participação dos funcionários, bem como das vantagens financeiras decorrentes de suas idéias" ( p.15).

" Um dia ... percebí que participar do sistema de sugestões era o único modo de reavivar meu valor como ser humano e de usar minha habilidade ao máximo no ambiente de trabalho. Então procurei a equipe que trata das sugestões " ( p. 27 ).

“ Eu ... havia recebido uma gratificação de 2 dólares por uma sugestão e prometí a mim mesmo que apresentaria as melhores sugestões da seção. Desde então, tenho feito inúmeras sugestões " ( p. 28 ).

"As questões pessoais ( horas de trabalho, salários, avaliação de desempenho e transferências ) deveriam ser discutidas em reuniões individuais com o supervisor... O sistema de sugestão não tem o poder para alterar a política de recursos humanos "( p. 74 ).

“ A maioria das sugestões é redigida em casa, pois geralmente não há tempo para fazê-lo na empresa. A redação de uma sugestão dá aos membros de sua família oportunidade de ajudá-lo na sua tentativa “ (p. 102$)$. 
"Comprei livros sobre melhoria, cadernos para tomar nota da idéias, lápis, borracha, etc, tudo para melhorar minha habilidade de fazer sugestões. Reinvisto minhas gratificações em coisas que me ajudam a fazer sugestões ainda melhores " ( $p$. $98)$.

A concepção que esta associação de recursos humanos possue do operário contrasta de forma significativa quando comparada com a visão da sócio técnica. Em que bases esta ingenuidade japonesa se sustenta, e por quanto tempo estas concepções lucrativas, mas alienantes, continuarão a vigorar ?

SATOSHI ( 1985, p. 17 ) comenta que “Esta submissão de cada um ( até em sua vida pessoal ) ao que se supõe ser uma necessidade da firma e da economia, essa plasticidade da força de trabalho $\mathrm{e}$ do povo japonês às necessidades do desenvolvimento do capitalismo, tudo isso repousou efetivamente numa adesão coletiva a um modo de desenvolvimento considerado pela maioria dos japoneses como natural, como algo sem alternativa possivel ".

MICKLETHWAIT \& WOOLDRIDGE ( 1998 ) alertam no entanto que algumas pressuposições da administração japonesa, como o consenso, funcionaram bem enquanto a economia do país estava crescendo $10 \%$ ao ano. Com o novo quadro recessivo, faz-se necessário a dispensa do excesso de funcionários, joint-ventures com empresas estrangeiras com cultura e processos decisórios diferentes. Estas mudanças podem abalar a relação do capital com o trabalho, trazendo um caráter mais político para a questão. 


\section{CAPÍTULO 7:}

\section{O ESTUDO DE CASOS}

O objetivo deste capítulo é apresentar a empresa onde foi desenvolvido um amplo diagnóstico de chão de fábrica, e os principais desdobramentos destes estudos, quais sejam a aplicação de duas ferramentas do sistema JIT: O gerenciamento visual da produção e o trabalho em grupos.

\section{1- A proposta}

A indústria nacional desde a abertura de mercado tem sido confrontada por uma necessidade de realinhamento de produtividade. O setor calçadista inclui-se entre aqueles que são sensíveis a concorrência interna e externa. Sempre tentando um equilibrio entre manter as exportações e atender o mercado interno, este mix de produção sofre desestabilizações diante de variações cambiais e diferentes políticas de exportação articuladas pelo governo brasileiro.

Com certa estabilização da economia e abertura de mercado, a indústria calçadista passou a uma necessidade de subtrair produtividade não em operações financeiras, mas sim das atividades pertinentes aos seus processos de transformação. Rever os procedimentos observados no chão de fábrica neste contexto foi algo fundamental, pressionado por contingências externas, conforme COLENCI \& CIOSAKI ( 1998 ). 
O estudo a ser apresentado foi realizado durante outubro de 1994 e abril de 1995 em uma tradicional indústria de calçadoș de couro masculino localizada na cidade de Franca, que empregava 700 funcionários, com uma produção média de 3.500 pares/dia. Esta produção destinava-se aproximadamente $75 \%$ ao mercado interno e o restante $25 \%$ à exportação. Faturava em torno de US\$: $120.000 /$ dia (cotação da data).

Fruto de uma preocupação de seus dirigentes com a produtividade de suas atividades de chão de fábrica, o estudo contemplou um diagnóstico das operações industriais mais próximas da realização das tarefas operacionais.

Como resultado, concebeu-se um novo modelo de trabalho em grupo dos operários bem como projeta e monitora a implantação de um sistema de gerenciamento visual da produção adaptado à indústria calçadista.

\section{2- ELABORAÇÃO DO DIAGNÓSTICO}

De forma simplificada; Bateman \& Snell ( 1998 ) assim representam o processo de diagnóstico e tomada de decisão:

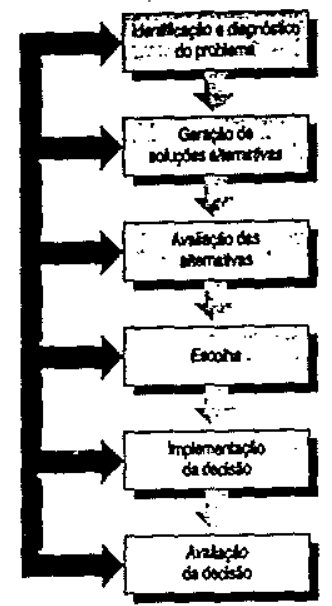

Figura 7.1- Processo de diagnóstico

Fonte: BATEMAN \& SNELL (1988, p. 95 ) 
O trabalho investigativo de diagnóstico não possuiu nenhum comprometimento com alguma ferramenta de produtividade pré-definida. Foram realizadas entrevistas com os principais agentes envolvidos e muita observação in loco onde os fatos relevantes aconteciam: O diagnóstico da empresa ficou restrito às áreas de produção e àquelas mais próximas à fabricação.

A partir desta massa de dados, as informações foram sistematicamente organizadas em dois blocos: O Sistema de Informações e o Sistema de Produção, a serem apresentados em sequência.

Com o diagnóstico realizado, foram apresentadas soluções que combinaram de forma criativa conceitos de produtividade, entre elas o gerenciamento visual da produção e o trabalho em grupos. Estas novas configurações sinérgicas foram cuidadosamente projetadas, testadas em projetos pilotos e implementadas com expressivos resultados para a organização.

\section{3- O SISTEMA DE INFORMAÇÃO}

O sistema de informação de uma organização é algo amplo e abrangente, envolvendo toda a complexidade de informações e dados que transitam pelos quadros internos da empresa, como também as comunicações da empresa com o seu ambiente, envolvendo fornecedores, instituições financeiras, mercado consumidor, governo etc.

O diagnóstico realizado focou as operações de chão de fábrica. Portanto nesta fase do trabalho estamos restringindo o sistema de informação como aquele necessário em proporcionar um suporte adequado as operações de fábrica, que envolveu os seguintes departamentos da empresa: 
VENDAS

PLANEJAMENTO \& CONTROLE DA PRODUÇÃO

MATERIAIS

COMPRAS

\subsection{1- VENDAS}

$O$ plano de vendas era acertado com 3 meses de antecedência, mediante estimativas de vendas e histórico de consumo. Ajustes mais finos eram realizados semanalmente, onde o que efetivamente ia ser produzido nas próximas semanas era acertado mediante planos semanais. Como regra, o produto apenas entrava para ser fabricado mediante pedidos confirmados de clientes.

Essas metas de vendas influenciavam todos os níveis de planejamento a ele subordinados. Como esperado, era comum o não atendimento de demanda em algumas linhas. $\mathrm{O}$ setor comercial queixava-se da ausência de feed-back de atrasos de produção pelo pessoal da fábrica. $O$ atraso médio da data de entrega acordado com a produção, em 24 amostras aleatórias, ficou em 4 dias.

\subsection{2- PLANEJAMENTO \& CONTROLE DA PRODUÇÃO}

A fábrica trabalhava com 10 linhas diferentes de calçados, com uma média de 6 modelos por linha de produto. Estas linhas tinham outra subdivisão de cores e 
matéria prima. A última chave de diferenciação do produto calçadista é a sua numeração, como representado esquematicamente.

\section{LINHAS}

MODELOS

\section{CORES E MATÉRIA PRIMA}

\section{NUMERAÇÃO}

Esta particularidade da industria, associado a flutuações e reprogramações de vendas, bem como uma politica de estoque de matéria prima com mínimos estoques de segurança ( $10 \%$ do planejado ) resultavam em grande complexidade das funções do planejamento.

O setor de planejamento-é um grande responsável pela harmonia e fluidez dos materiais nos processos de fabricação. A matéria prima básica do PCP são informações confiáveis.

O sistema de PCP era realizado manualmente, resultando em muito trabalho e pouco resultado. Com frequencia os planejadores de materiais eram chamados a dar assistência a produção.

Fichas de produção, ou ordens de fabricação que autorizavam a fabricação de uma grade de 12 pares de calçados, eram iniciadas e não terminadas por falta de algum item de matéria prima. Os PCP controlava por volta de 900 itens, e $80 \%$ das faltas de materiais na fábrica eram de ítens sob responsabilidade do PCP. Visível o desequilibrio causado pelo Planejamento mal conduzido. 


\subsection{3- MATERIAIS}

As baixas de estoque não estavam integradas via sistema. Assim, o controle de matéria prima apresentava inconsistências, pois as baixas de estoques eram realizadas em períodos mensais, semanais ou diários, conforme o tipo de produto.

A sistemática de registro de matéria prima não especificava claramente numerações ou formas, sendo aparente que o sistema mais servia de fonte de informações contábeis do que uma fonte fiel para o planejamento e a fábrica.

Aproximadamente $15 \%$ dos produtos constantes em lista de materiais não eram mais utilizados, e continuavam cadastrados. Existiam muitos produtos com duplicidade de cadastro.

O sistema informatizado, como visto, ficou sujeito a muitas inconsistências. $\mathrm{O}$ procedimento operacional contribuía para o descrédito de tal forma que o sistema paralelo de ficha Kardex era mais confiável para os usuários da informação.

Sem informações exatas das necessidades de materiais e o PCP sendo processado manualmente, a fábrica se mostrava desprovida de um sistema de apoio adequado.

\subsection{4- COMPRAS}

Parte significativa do plano de compras estava subordinado ao plano de vendas trimestral. Porém $60 \%$ da faltas de materiais ocorridas tinham origem na não comunicação de mudanças efetuadas pela produção e planejamento. O sistema de compras não estava integrado com o sistema de PCP. 


\section{4 - O CHÃO DE FÁBRICA}

As atividades de chão de fábrica foram diagnosticadas em blocos mais significativos de fabricação, assim delimitados:

CORTE

PREPARAÇÃO

PESPONTO

ESTEIRA MONTAGEM/ACABAMENTO

\subsection{1- SISTEMA TAREFEIRO}

O sistema de remuneração dos funcionários na empresa era um sistema misto. Existiam dois grupos de operários: os que recebiam como mensalistas e aqueles que recebiam por tarefas realizadas, ou sistema tarefeiro, ou ainda pecistas.

No final do dia todos os funcionários tarefeiros passavam para o chefe de seção quais tarefas foram realizadas no dia e em que quantidade. Cada tarefa realizada possuía um preço diferente, ou seja, a tarefa de chanfrar um modelo era diferente de outro. 
Quando porventura não existisse trabalho para ser realizado, o funcionário marcava em sua ficha o tempo como hora parada. $\mathrm{O}$ departamentó pessoal pagava estas horas pelo salário base da categoria de registro na carteira de trabalho.

$O$ departamento pessoal possuia um sistema informatizado que processava todas as operações realizadas pelos funcionários tarefeiros à cada dia. Assim era calculado o salário do operário no final do mês.

O sistema tarefeiro apresentava ótimos rendimentos individuais, quando existia demanda suficiente. A produtividade individual era expressiva, atestado visualmente pelo ritmo intenso de trabalho.

Porém a produtividade global não acompanhava este ritmo intenso de trabalho. Ou seja, muito esforço era realizado para produção de inventário em processo. Existia grande pressão sobre a chefia e o PCP para "soltar " a produção.

Os problemas com qualidade e retrabalho não permitiam a identificação da fonte geradora do defeito. Os erros perdiam-se entre a grande quantidade de funcionários que manipulavam o produto semi -elaborado.

\subsection{2- CORTE}

O corte é a primeira etapa do processo de fabricação de calçados. Dele resulta um bom aproveitamento das peles. O profissional precisa estar capacitado para todas as particularidades desta fase como um bom aproveitamento das partes nobres do couro, como o dorso, ou um direcionamento secundário para peças resultantes da barriga da pele. 
Por isso, o operário do setor de corte tem uma função importante para o fabricante de calçados. Ele é polivalente devido a própria natureza de seu trabalho, isto é, pode cortar diversos tipos de produtos, alterando apenas as facas utilizadas para o corte.

O equipamento padrão do setor são os balancins de corte. Poucas peças são cortadas manualmente ( sem o auxílio do balancim ). A regulagem de pressão e altura de corte são fáceis e simples de serem efetuadas pelo funcionário.

É este setor que pressiona o planejamento da produção a mandar para dentro da fábrica as fichas de montagem de calçados. Como ganha-se por tarefas realizadas, o corte praticamente puxava o planejamento. Devido ao descontrole do planejamento, como visto anteriormente, era a produção que forçava o início das fichas de produção, e o corte tinha papel determinante nesta inversão de funções.

$\mathrm{O}$ estoque em processo apurado no setor foi de 1,22 dias de estoque em processo, e 0,8 dias de estoque já terminado, mas ainda localizado no setor dentro de caixas.

Parte da produção era cortada em bancas de corte, externas à empresa.

\subsection{3- PREPARAÇÃO}

Após o corte as peças precisam passar por transformações para sofrerem posteriormente operações de colagem, costura etc. Estas operações acontecem no setor de preparação.

Operações de chanfrar são típicas desta fase. As operações são realizadas em bancadas com geralmente uma máquina. São comuns colagens com máquinas ou 
marteletes, divisão da vaqueta, dobrar as peças cortadas em máquinas ou operações manuais e confecção de enfeites. $O$ setor contava com 43 funcionários horistas e pecistas.

Parte da produção do setor era terceirizada para bancas de preparação. Após o corte as peças eram encaminhadas diariamente para estas operações fora da fábrica.

As funcionárias são bastante flexíveis, e as máquinas fáceis de serem reajustadas. $O$ estoque em processo aferido no local foi de 2,51 dias, muito alto quando considerada a simplicidade das operações envolvidas.

\subsection{4- PESPONTO}

A configuração física do setor de pesponto constava de duas esteiras ( A e B ) de distribuição de serviços, com bancadas individuais distribuídas ao longo das laterais das esteiras. Estas esteiras eram comandadas por dois chefes de setores que faziam o encaminhamento de serviços para os funcionários. A esteira de pesponto $\mathrm{B}$ era mais direcionada para produtos de exportação. As esteiras juntas possuiam 140 funcionários.

As operações realizadas em cada par de calçados apenas no pesponto variavam de 20 a 40 operações diferentes. Algumas operações como costura manual ou dobras, que não envolviam diretamente as máquinas de pesponto, também eram realizadas ná seção.

Grande parte dos funcionários do setor eram peçistas, e atendiam diariamente muitos modelos diferentes. As máquinas de pesponto eram facilmente configuradas para mudar de operações, bastando ajuste manual e eventual troca de linha. 
Os operários geralmente trabalhavam com duas fichas em cada bancada. Uma em operação e outra aguardando ser processada. Esta condição era importante para não existir descontinuidade de serviço, visto que eles eram pagos por operações realizadas.

Como é comum no setor calçadista, parte da produção de pesponto era terceirizada para bancas de pesponto. Na empresa, aproximadamente $40 \%$ do serviço de pesponto era realizado por bancas. Estes prestadores de serviços eram na maioria administrados por pessoas que trabalhavam na própria organização, o que facilitava procedimentos de distribuição, pagamentos e controles. Operações que demandavam mais rigor e qualidade eram conservadas dentro da empresa.

Muitas operações e muitos modelos, alimentados por um sistema tarefeiro elevavam a desorganização do setor e sobrecarregava os chefes. O estoque em processo médio apurado foi de 1.86 dias.

\subsection{5- ESTEIRA DE MONTAGEM E ACABAMENTO}

A finalização do processo de fabricação acontecia nas esteiras de montagem e acabamento. Existiam 4 grandes esteiras na fábrica em questão, sendo que cada esteira possuia alguma característica mais particular, sendo mais apropriada para alguns modelos de produtos.

Nestas esteiras eram realizadas todas as operações de montagem do produto, com utilização de máquinas específicas de modelagem, fixação, colagem, acabamento superficial, brilho etc. A flexilibidade era relativa, pois muitos modelos diferentes eram processados simultaneamente, porém algumas máquinas eram reguladas para uma linha específica, demandando muito tempo para uma ajustes e set-up.

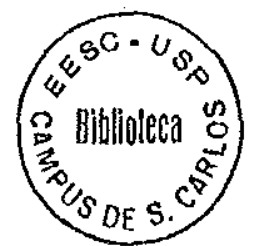


Nesta fase o produto recebia materias de terceiros como solados, saltos, unissolas, embalagem etc. $O$ estoque em processo apurado foi de 1,13 dias.

Atuando como um estoque típico aguardando para entrar na esteira, ou para atenuar eventuais faltas de componentes, existe na esteira alguns pontos de fuga, denominados gancheiras, onde os produtos ficam em compasso de espera.

\section{5- ESTOQUE EM PROCESSO}

Estoques são indicativos de ineficiências, desbalanceamentos, presença de gargalos de produção e problemas de planejamento. Assim, um elemento indicador nos diagnósticos de chão de fábrica é um bom rastreamento dos estoques em processo. Por isso detalhamos de forma mais cuidadosa o inventário em processo na empresa.

\subsection{1 - INVENTÁRIO ENTRE PROCESSOS}

Durante 15 dias foram apurados os estoques em processamento nas principais seções, e o estoque entre estas seções. Os resultados já foram apresentados no ítem 7.4 e este tópico apenas consolida este levantamento. $O$ inventário em processo ( em dias ) é apurado dividindo-se a quantidade de produtos físicos presentes na seção pela produção média diária no periodo. O resultado é apresentado na tabela abaixo: 
Tabela 7.1- INVENTÁRIOS NA FÁBRICA

$\begin{array}{lcc}\text { SEÇÃo } & \text { INVENTÁRIO (dias) } & \text { CÁLCULO } \\ \text { corte } & 1,22 & 3193 / 2600 \\ \text { corte/preparação } & 0,87 & 2265 / 2600 \\ \text { preparação } & 2,51 & 4778 / 1900 \\ \text { preparação/pesponto } & 0,24 & 455 / 1900 \\ \text { pesponto } & 1,86 & 3013 / 1620 \\ \text { SUB TOTAL } & 6,70 & \\ \text { pesponto/cost. man. } & 0,68 & 1100 / 1620 \\ \text { gancheiras } & 0,50 & 1310 / 2600 \\ \text { TOTAL PARCIAL } & 7,88 & \end{array}$

Não estão contabilizados neste levantamento o estoque nas esteiras de montagem e acabamento, bem como o material em terceiros nas bancas de preparação e pesponto.

\subsection{2- LEAD TIME DE PRODUÇÃO}

Foi realizado um levantamento em 103 amostras aleatórias de produtos de 5 linhas representativas diferentes para apuração de Lead Time de produção. Estas amostras apuraram os dias úteis entre a data que o produto entra no setor de corte, a primeira operação do processo, e a data que o produto entra na expedição, a última operação do processo. Estas datas são conseguidas pelas anotações efetuadas nas fichas de produção.

O tempo efetivo de produção nesta amostra ficou assim representado: 
Tabela 7.2- LEAD TIME DE PRODUÇÃO

$\begin{array}{lcc}\text { Produto } & \text { Lead Time (dias ) } & \text { amostras } \\ \text { A } & 13,3^{\prime} & 23 \\ \text { B } & 12,7 & 20 \\ \text { C } & 12,9 & - \\ \text { D } & 6,4 & 17 \\ \text { E } & 12,0 & 21 \\ \text { TOTAL } & 10,4 & 22\end{array}$

Observar neste levantamento que o produto $D$ era um modelo destinado a exportação, com poucas variedades de modelo e grandes quantidades. Possuia um processo de produção, desde o corte até o acabamento, praticamente dedicado a ele, o que imprimia uma característica de produção de alto volume e pouca variabilidade.

\section{6- PRINCIPAIS CONCLUSÕES}

Como resultado do diagnóstico, pode-se sintetizar os principais resultados da seguinte forma:

- Um planejamento e controle da produção deficiente, com sistemas de explosão de necessidades manuais diante de uma produção complexa e aliada a um sistema de remuneração tarefeiro resulta em uma produção desbalanceada, altos estoques em processo, sem um comando efetivo do setor de planejamento, apesar da flexibilidade da produção.

- Diversas linhas e modelos de produtos em uma configuração de fábrica com postos de trabalho isolados e distantes, alimentados por esteiras, resulta em elevados Lead Times de produção e altos estoques em processo. 
- Um planejamento da produção frágil, aliado a produção complexa e sistema tarefeiro faz com que a produção puxe o planejamento, e não o contrário. O PCP apresenta-se de forma reativa no processo, e não o contrário.

- A falta de integração entre as informações de fábrica prejudicava todo o sistema de produção, materiais, compras e vendas.

- O sistema tarefeiro implantado na empresa criou uma cultura de ótimos locais desintegrados, que não resultava em melhores índices globais de produção, mas pelo contrário, gerava altos níveis de inventários e desbalanceamentos. 


\section{CAPÍTULO 8:}

\section{MEDIDAS DE RACIONALIZAÇÕES}

Diante do exposto no diagnóstico de chão de fábrica realizado, foram propostas algumas medidas para melhorar o processo de produção da empresa. Estas sugestões foram apresentadas e discutidas com os funcionários da organização, resultando em um Plano de Ação e a implantação de um Projeto Piloto, que foi posteriormente expandido para uma parte da fábrica. Este capítulo apresenta estas medidas de melhorias.

\section{1- Metas de redução de inventários}

O levantamento de informações realizado proporcionou o estabelecimento das seguintes metas de redução de inventários, e respectivo ganho financeiro apenas com materiais:

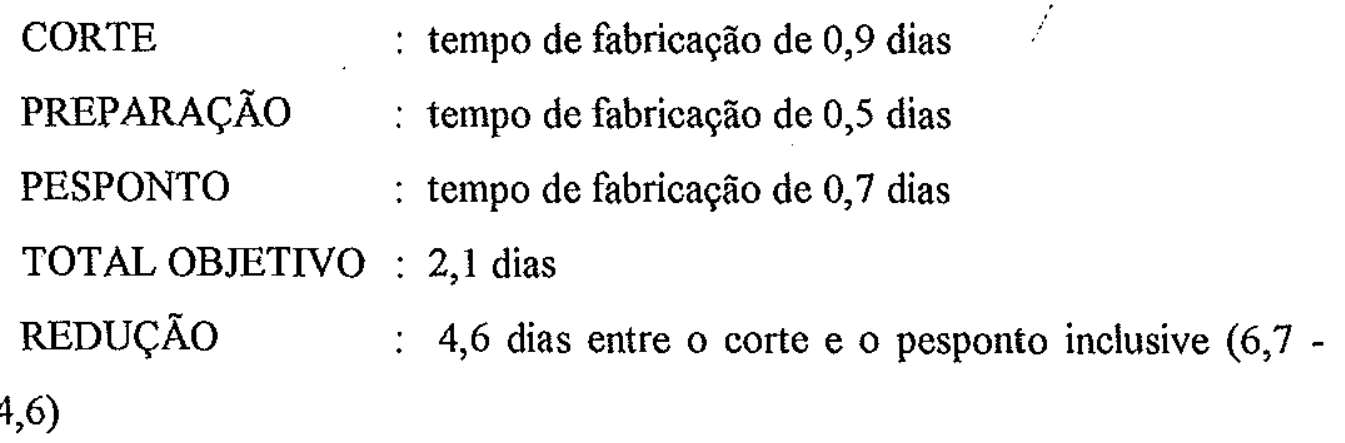


Esta redução representa uma economia mensal de U\$\$35.880 ( 4,6 X $120.000 \times 0,065=35.880)$ apenas com os custos de desconto de duplicata sobre o capital de giro praticados na época $(6,5 \%)$. Algumas medidas para alcançar esta redução são apresentadas a seguir.

\section{2- O SISTEMA DE INFORMAÇÃO}

Apesar de ser uma organização industrial, o processo de informatização teve início nos setores financeiros e contábeis, sendo perceptível a renegação dos sistemas de produção e apoio a produção.

Por ser muito mais específico e complexo de ser desenvolvido, os sistemas de produção foram sendo deixados de lado, resultando em uma situação caótica para a fábrica, planejamento, compras e materiais. O sistema de informatização da empresa apresentava-se completamente desintegrado e fragmentado.

É notório que o PCP é o grande maestro, o direcionador dos recursos da fábrica. " O PCP deve ser considerado como um conjunto de funções para a qual convergem informações, que serão transformadas, convenientemente, para fabricação, compras e vendas e em informações para previsões e controles " SILVA ( 1994 ). Assim, um PCP frágil, praticamente realizado sem auxilio de meios informatizados, é um grande foco de instabilidade para todas as áreas relacionadas com o planejamento.

A medida sugerida para estes problemas foi a aquisição ou desenvolvimento de sistemas próprios para a produção. Pesquisas foram realizadas com diversos fornecedores de pacotes tipo MRPs. Após estudos realizados pelos responsáveis pela Informática, optou-se pelo desenvolvimento interno por terceiros de um sistema de PCP. Este desenvolvimento seria realizado por um analista pleno, um analista programador e um programador, consumindo 7 meses de trabalho. 
Este sistema precisaria fazer a "explosão" de necessidades de materiais, integrando as informações de estoque, compras e área comercial Optou-se pela não inclusão de planejamento de necessidade de capacidade. A interface com a fábrica continuaria sendo feita mediante as fichas de produção.

Além disso foi realizado um grande saneamento nos ítens sem utilização constantes em listas de matéria prima, a conversão de unidades de produtos em apenas uma forma de mensuração, a alteração na forma de fazer os lançamentos de estoque de forma a moralizar e forçar a sábia utilização do sistema de controle de estoque.

RESENDE (1989), SACOMANO ( 1990) e colaboradores desenvolveram diversos sistemas de PCP, de alta relevância que oferecem contribuição ao entendimento do assunto.

\section{3- O CHÃ̃ DE FÁBRICA}

Por determinação da diretoria da empresa, as medidas de racionalizações deveriam contemplar apenas os setores de corte, preparação e pesponto. Desta forma, as operações nas esteiras de montagem e acabamento e as operações realizadas nas bancas de preparação e pesponto ficaram fora do escopo do estudo.

Dada esta condição de contorno, ou limitação auto imposta pela organização, foram apresentadas 3 frentes de atuações para a melhoria de eficiência e eficácia nas operações do chão de fábrica:

- Organização de grupos de trabalho

- Gerenciamento visual da produção -

- Alterações do sistema tarefeiro 


\section{4- ORGANIZAÇÃO DE GRUPOS DE TRABALHO}

As diversas operações realizadas individualmente por diferentes funcionários, se agrupadas em um grupo de trabalho, trariam uma nova identificação de unidade de trabalho. Substitue-se o indivíduo pelo grupo, a operação individual pelo produto feito, a tarefa pelo processo.

Trabalhar em grupos, com uma nova sistemática de organizar o trabalho e direcionar o serviço, trariam em tese menor Lead Time de produção, menos inventário em processo, melhor desempenho de entrega de produtos acabados, melhor qualidade, enriquecimento do trabalho, menor fadiga para o trabalhador e melhor horizonte para o setor comercial. Estes beneficios objetivados são muito importantes em termos de uma melhoria de produtividade industrial.

Duas necessidades básicas para a organização por grupos de trabalho é a flexibilidade da mão de obra e a flexibilidade de produção. Os setores de corte, preparação e pesponto possuíam estes dois atributos para uma adequação ao trabalho em grupos, em detrimento do trabalho individual verificado.

A fabricação verificada na empresa trabalhava simultaneamente com muitas operações e modelos diferentes. A flexibilidade de produção precisava ser preservada a qualquer custo, ou seja, não seria viável uma célula dedicada a apenas um tipo de produto ou uma gama muito restrita de produtos, salvos produtos direcionados para exportação, e mesmo assim com ressalvas.

Por isso a melhor configuração de fábrica não seria aquela tradicional mini fábrica, mas um misto entre um lay-out departamental e um lay-out celular, como pode ser observado na figura 8.1. 

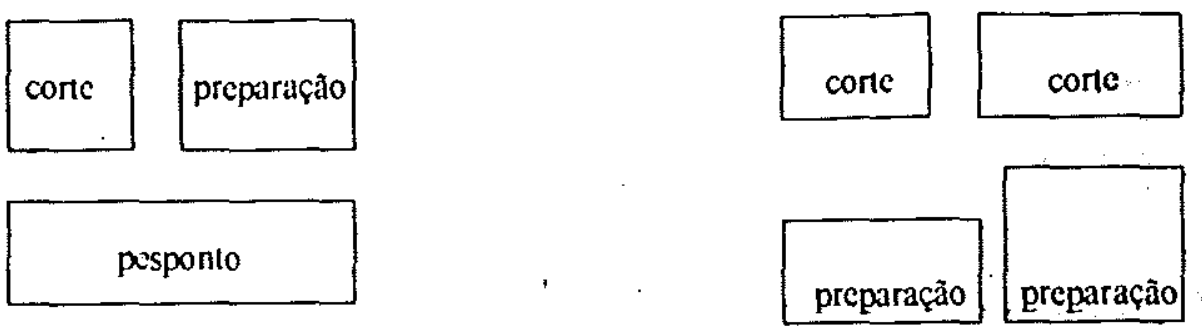

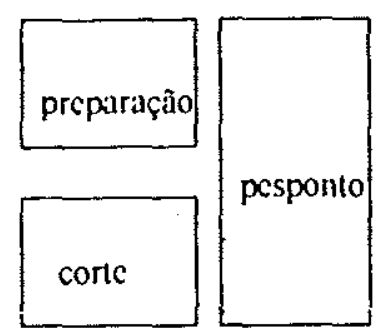

Nảo em mini fahricas

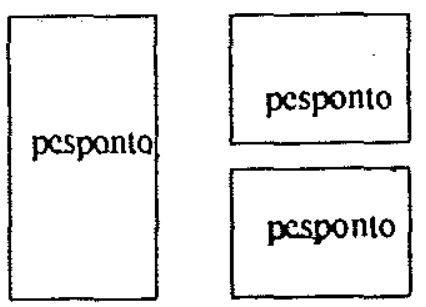

mas uma configuração mixta

Figura 8.1- Organização parcial da fábrica

A organização por grupos de trabalho nos três setores pode ser assim apresentado:

\subsection{1- CORTE}

Neste setor, pela própria característica do trabalho em balancins, onde cada operador já faz praticamente toda a ficha de componentes de couro, a proposição foi arrumar o lay-out dos postos de trabalho de forma a aproximar em quatro grandes grupos usando como argumento a similaridade de sub componentes utilizados.

Esta nova configuração facilita o gerenciamento do trabalho pela chefia, reduz o fluxo entre o setor para fechar as fichas e permite uma melhor distribuição dos faqueiros, aproximando as ferramentas do local de utilização. 
Foi feito um treinamento de conscientização com a chefia do setor junto com o PCP para serem liberadas apenas fichas com todo o material já a disposição. Como será visto em sequência, o gerenciamento visual da produção contribui para que não aconteça um excesso de fichàs no corte.

Os quatro grupos de corte ficaram assim configurados:

\section{Tabela 8.1- SUGESTÃO DE GRUPOS DE CORTE}

GRUPO

01

02

03

04

\section{PRODUTOS}

A, E e outros

$\mathrm{B}$ e outros

C e outros

D e outros

\section{CARACTERÍSTICA}

espuma lateral, forro e inter tela

pelica, intertela e forro

apenas forro

exportação

\subsection{2- PREPARAÇÃO}

Operações simples, máquinas fáceis de ajustar, sem praticamente tempo de set-up, características de produção similares, operárias flexíveis tornou a preparação um objetivo convincente para o trabalho em grupo.

O inventário na seção iria cair na medida em que cada célula trabalharia com uma quantidade controlada de fichas de produção, sendo que no método atual cada operário trabalhava com 2 a 3 fichas na bancada.

A operação que é determinante na preparação é o chanfro. As demais operações como colagens e dobras são feitas em sua função. Alguns modelos exigem mais operações que outros. 
Assim, os grupos de trabalhos foram sugeridos e dimensionados pela capacidade da máquina de chanfrar. Ela é que determinava a capacidade de produção do grupo. Devido a diversidade de modelos, os grupos ficaram dimensionados entre 2 e 6 funcionárias.

Algumas máquinas do setor tinham uso em comum, como a picotadeira, a máquina de dividir couro e a dobradeira. Foi sugerido uma configuração onde estes recursos ficavam posicionados para prestar serviços as demais células, de forma rápida, conforme a figura 8.2 .
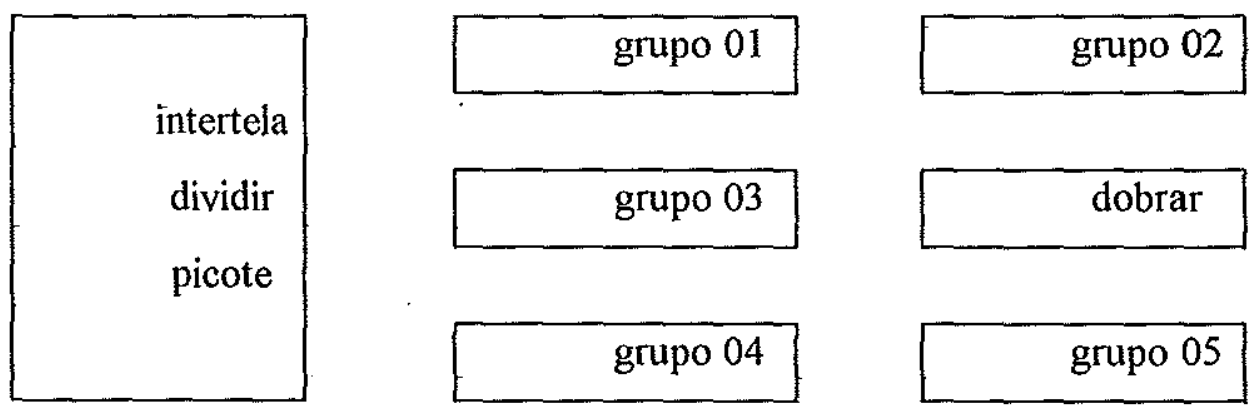

Figura 8.2- Grupos na preparação

Foram organizados 6 grupos de trabalho além dos dois grupos de apoio. Eles ficaram assim configurados: 


\section{Tabela 8.2- SUGESTÃO DE GRUPOS NA PREPARAÇÃO}

$\begin{array}{lll}\text { GRUPO } & \text { PRODUTOS } & \text { CONFIGURAÇÃO } \\ 01 & \text { A } & 1 \text { chanfradeira e } 3 \text { bancadas } \\ 02 & \text { B e outros } & 2 \text { chanfradeiras e } 2 \text { bancadas. } \\ 03 & \text { C e outros } & 2 \text { chanfradeiras e 2 bancadas } \\ 04 & \text { D } & 2 \text { chanfradeiras e } 4 \text { bancadas } \\ 05 & \text { E e cromo } & 1 \text { chanfradeira e 1 bancada } \\ 06 & \text { diversos } & 2 \text { chanfradeiras e 2 bancadas }\end{array}$

Procurava-se encaminhar os produtos para a célula mais apropriada, para um melhor aproveitamento dos recursos de produção. Enfatiza-se que as células são flexíveis para atender qualquer tipo de trabalho.

\subsection{3- PESPONTO}

Como na preparação, os operários desta seção eram bastante multifuncionais, podendo realizar diversos tipos de costura diferentes. Obviamente cada um tinha uma gama de preferências próprias onde o serviço se desenvolvia com maior agilidade. As máquinas eram facilmente preparadas para atender diversos tipos de produtos, bastando ajustes de altura e troca de linhas. $\mathrm{O}$ setor era facilmente reconfigurável em termos de lay-out.

A facilidade de transformar as operações individuais em grupos de trabalho, e os beneficios associados já citados, levaram a apresentação de uma transformação de todas as duas esteiras da seção.

A flexibilidade de produção, nesta etapa em especial, precisava ser preservada. Assim apesar dos grupos de trabalho terem sido idealizados tendo como base a 
similaridade de produtos, cada grupo poderia trabalhar com qualquer linha de calçados.

Procurou-se agrupar funcionários com o mesmo rítmo de trabalho, pois a grande maioria dos colaboradores eram pecistas. Enfatizou-se a necessidade de um esforço de treinamento e conscientização para que o trabalho fosse mudado de individual para grupo.

Os grupos foram dimensionados também pela capacidade de máquina. Alguns recursos eram compartilhados com todos os outros grupos, como o ponto luva e o vivo argentino ( operações especiais de pesponto ). Estes últimos foram caracterizados como grupos de prestação de serviço para os outros grupos do pesponto.

Cada grupo de trabalho sugerido será composto de 3 a 6 profissionais, tanto de pespontadores como de operações de bancadas manuais. Preliminarmente, eles ficaram assim configurados:

\section{Tabela 8.3- SUGESTÃO DE GRUPOS NO PESPONTO}

$\begin{array}{ll}\text { GRUPO } & \text { PRODUTOS PRINCIPAIS } \\ \text { tipo 01 } & \text { A, E e outros } \\ \text { tipo 02 } & \text { B e outros } \\ \text { tipo 03 } & \text { Cromo e e outros } \\ \text { tipo 04 } & \text { D e outros } \\ \text { tipo 05 } & \text { Bambolim } \\ \text { tipo 06 } & \text { Ponto luva e vivo argentino }\end{array}$

Existiam diversas unidades de cada um dos grupos. $\mathrm{O}$ produto $\mathrm{C}$ era pespontado por terceiros. 
Com 140 funcionários no setor, um dimensionamento superficial permite prever 120 funcionários nos grupos de pesponto.

\section{5- GERENCIAMENTO VISUAL DA PRODUÇÃO}

Reformulando o sistema de PCP espera-se uma melhor coordenação dos recursos utilizados pela produção. Substituindo o trabalho individual por trabalho em grupo espera-se um melhor aproveitamento dos recursos mais próximos ao nível da tarefa.

Porém a articulação entre o planejamento e a fabricação continua sujeito a um sistema que remunera a produção por volume, realizado mediante fichas de produção e com níveis elevados de produtos semi elaborados, como observado.

O gerenciamento visual da produção vem adicionar um componente de produtividade entre o planejamento e a fabricação em sí, trazendo mais transparência na distribuição das fichas pelo PCP, e também tornando claro e verificável o trânsito destas fichas entre o corte, preparação e pesponto.

O objetivo a perseguir é, dentro de uma filosofia just in time, não deixar faltar material de trabalho para nenhum grupo de trabalho. $\mathrm{E}$ também não deixar material em excesso na seção.

O monitoramento do fluxo de materiais dentro das seções e entre as seções será exercido pelos chefes de seção, porém com o apoio de uma ferramenta simples e eficaz, sem alterar o sistema de fichas consagrado dentro da fábrica.

Monitorar produtos em elaboração individualmente, neste tipo de indústria, é impossível. Necessário se faz a adoção de uma unidade de ajuntamento padrão, 
função dos containers no kanban. A medida escolhida foi o próprio volume de pares de produtos comandados por uma ficha de produção, que já seguem dentro de caixas plásticas.

Uma forma encontrada de tornar a produção visível foi instalar dois tipos de quadros de acompanhamento da produção. Um tipo de quadro, o quadro de produto acabado, gerencia as fichas já processadas na seção e que estão. à espera da próxima operação. $O$ outro tipo de quadro monitora as fichas que estão sendo processadas na seção. Todos os quadros possuem sub divisões de linhas principais de produtos e alguns ainda por grupos de trabalho. Estes quadros podem ser melhor visualizado na figura 8.5 .

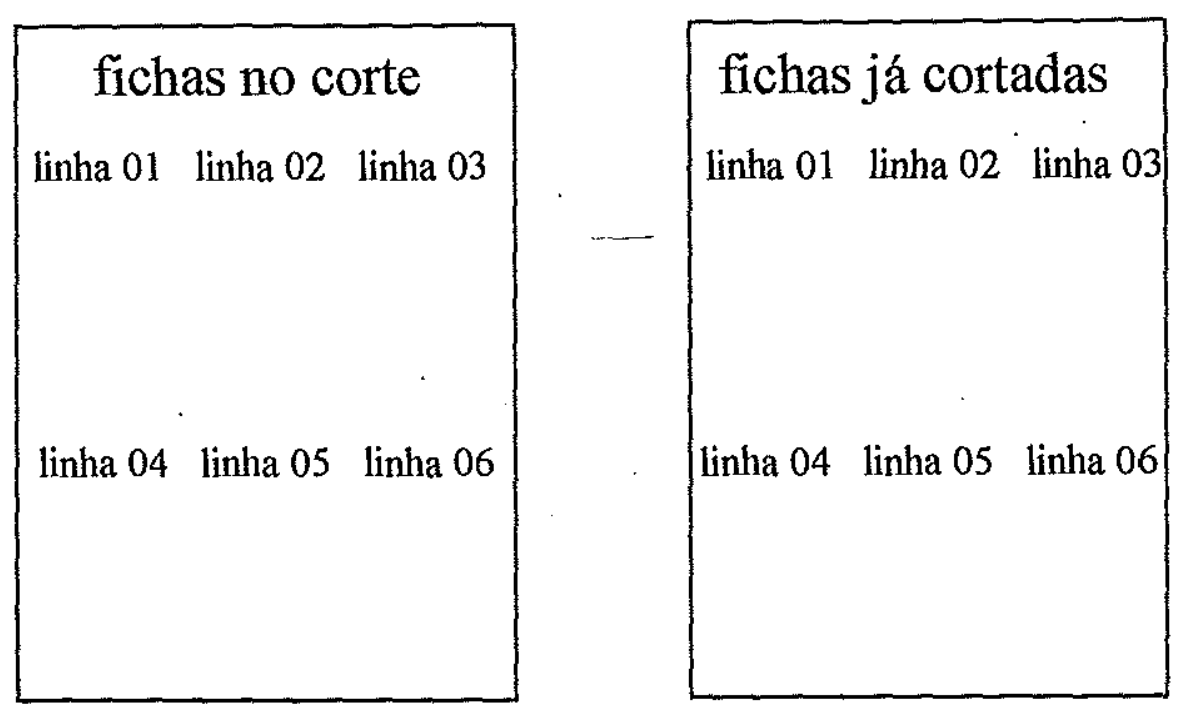

Figura 8.5- Quadros de Gerenciamento Visual da Produção

Uma quantidade muito grande de fichas eram manipuladas simultaneamente nas seções, o que tornava inviável a implantação de cartões de produção como no sistema kanban, pois a grande quantidade dos cartões iria requerer painéis muito grandes e de dificil manipulação.

O meio de monitorar as fichas visualmente foi contornado utilizando-se duas pequenas bolinhas de cores diferentes, tipo alfinete. Cada ficha emitida pelo PCP iria acompanhada de 2 alfinetes com bolinhas coloridas. Uma delas serviria para 
acompanhar os produtos acabados, e a outra para alimentar o painel de produtos em processamento na seção.

$O$ novo procedimento operacional funcionaria da seguinte forma: $O$ responsável pelo setor de corte foi até o almoxarifado de couro, e percebeu que o PCP liberou uma ficha para um certo produto. Estas fichas liberadas já estariam acompanhadas de 2 bolinhas/alfinetes coloridos. Quando o corte pega a vaqueta para a ficha, o responsável coloca a bolinha correspondente ao estoque em processo ( vermelha por exemplo ) no painel de estoque em processo. A ficha, com a outra bolinha colorida de estoque acabado ( verde, p. ex. ), continua a seguir junto com a caixa plástica nos balancins . Quando a operação de corte é terminada, e a ficha está a disposição da preparação, o responsável retira a bola vermelha do painel de estoque em processo, coloca este bola na ficha correspondente, e retira a outra bola (verde ) da ficha, anexando-a no painel de estoque acabado. Quando a ficha começa a ser transformada pela preparação, o responsável pelo setor retira a bola verde do painel e coloca na ficha, e transfere a ficha vermelha para o painel de estoque em processo na preparação, e assim consecutivamente.

Desta forma, todo o fluxo de fichas entre o almoxarifado de couro e o pesponto estaria visualmente representado pelos painéis, diferenciando estoque em processo na seção com fichas esperando processamento, fornecendo facilidade aos chefes de seção na distribuição e administração dos inventários, bem como facilitando a gerência e diretoria um controle visual em tempo real dos níveis em estoque na fábrica.

Percebe-se que cada ficha de produto sempre vai estar acompanhada de uma bola colorida. Este também é um instrumento simples e fácil de auditar se não está existindo a introdução de fichas sem o devido registro nos paineis. Nenhuma ficha pode estar "solta" na șeção, ou seja, sem uma ou outra bola colorida. Segundo nosso exemplo, toda ficha em processo de transformação precisa estar com a bola verde anexada na ficha ( e vermelha no painel de produção ), e toda ficha esperando entrar 
na seção precisa estar acompanhada da bola vermelha na ficha (e verde no painel de estoque em processo).

O gerenciamento visual da produção como concebido é uma ferramenta fácil de administrar, depois de entendido o seu funcionamento. É alimentada em tempo real pelos próprios operários ou responsáveis . Fornece fortes indicativos de intervenção rápida para a chefia e gerência, facilitando o trabalho de planejamento próximo da tarefa e dando informações para o estabelecimento de prioridades de produção.

\section{6- ALTERAÇÕES DO SISTEMA TAREFEIRO}

O sistema tarefeiro estava culturalmente instalado na empresa, elevando a produtividade individual dos operários, bem como uma grande disponibilidade dos operários para permanecer fora do horário para terminar certo serviço urgente. Também como já visto, as grandes penalidades do sistema era gerar altos índices de inventário em processo, produção sem responsabilidades e principalmente não objetivar o ótimo global da empresa, mas somente ótimos locais.

Como manter a produtividade e reduzir os efeitos colaterais do sistema?

A primeira grande alteração foi efetuar o pagamento pela produtividade do grupo de trabalho. Se a nova unidade de produção era o grupo de trabalho, nada mais justo que efetuar o pagamento pela produção do grupo.

Estabelecer o valor de cada par de calçados para a preparação e o pesponto, contando com a base de dados do sistema tarefeiro, é missão simples, bastando para isto um somatório das operações individuais. 
Uma vez apurado a produção do grupo, o resultado monetário apurado seria dividido proporcionalmente ao salário base de cada funcionário. Assim seria respeitado as diferentes qualificações entre as células.

Como as células poderiam ser reconfiguradas ao longo da semana, a produção seria fechada diariamente.

O processamento de informações pelo RH passaria a ser feito não mais por operações, mas por pares de calçados, reduzindo sensivelmente o volume de dados manipulado.

Acertado os detalhes operacionais da nova sistemática de trabalho, faz-se necessário um grande trabalho de conscientização e treinamento dos funcionários de chão de fábrica para uma efetiva adesão.

A diretoria, diante dos ganhos oriundos da redução de giro exposto no ítem 8 , decidiu aumentar o valor do preço pago pelas peças em $15 \%$ para o setor de pesponto, em caráter emergencial para minimizar resistências e facilitar o processo de migração de um sistema para outro. Ficou enfatizado a transitoriedade da medida, em face dos possíveis ganhos de produtividade do trabalho em grupo.

A folha de pagamento líquida dos 2 setores era de $\mathrm{R} \$ 32.125,00$ incluído horistas e tarefeiros. Com um adicional de $15 \%$ os gastos da empresa com esta liberalidade seria de $\mathrm{R} \$ 7.959,00$ incluído $65 \%$ de encargos sociais. Dentro de uma certa previsão, haveria uma sobra de caixa mensal para a empresa de R\$27.921 $(35880-7959)$. 


\section{Capítulo 9: \\ PROJETO PILOTO E IMPLANTAÇÃO}

Com as medidas de racionalização apresentadas, partiu-se para um projeto piloto de um grupo de trabalho na preparação e outro no pesponto. O projeto piloto tem como atributo principal verificar se a realidade vai corresponder de forma adequada aos fundamentos teóricos apresentados, e fornece indicativos para as adaptações necessárias caso o projeto venha a atingir as dimensões que ele se propõe.

\section{1- O PROJETO PILOTO NA PREPARAÇÃO}

O chefe de seção da preparação escolheu 4 funcionárias horistas para a experiência piloto. Procurou-se direcionar produtos A para a célula, que ficou assim configurada:

$\begin{array}{lll}\text { GRUPO } & \text { PRODUTOS } & \text { CONFIGURAÇÃO } \\ 01 & \text { A } & 1 \text { chanfradeira e } 3 \text { bancadas }\end{array}$

Este grupo de trabalho ficou ${ }^{-}$em experiência por volta de 3 meses. Nos primeiros dias a célula, composta de horistas, alcançou a produção de 128,5 pares/dia. 
A média dos tarefeiros para o mesmo produto em operações individuais era de 151,2 pares/dia.

O estoque em processo reduziu-se para 36 pares, pois o grupo todo trabalhava com apenas uma ficha na mesa e duas fichas aguardando processamento. Desta forma o giro foi reduzido para 0,28dias $(36 / 128,5)$, contra 2,51 dias levantado anteriormente. A produção que entrava na célula saía rapidamente, não acumulando estoques intermediários entre as diversas operações na preparação. Ficha iniciada era ficha terminada.

A preocupação nesta fase foi com a produção abaixo do esperado. Após reunião com a diretoria da empresa, foi estabelecido em comum acordo um estímulo de produção para o grupo de trabalho piloto da preparação, nos seguintes moldes:

produção de 160 à 169 pares: acréscimo de 5\% no salário base produção de 170 à 179 pares: acréscimo de $10 \%$ no salário base

Depois de comunicado estas medidas aos componentes do grupo, nos 5 dias seguintes a produção média ficou em 173,2 pares/dia, reduzindo mais ainda o giro da seção. No mês seguinte a implantação desta medida de estímulo a produtividade, o adicional de salário pago aos componentes do grupo foi de $6,49 \%$.

\section{2- O PROJETO PILOTO NO PESPONTO}

Como projeto piloto, implantou-se 4 grupos de produção de pesponto, assim constituídos: 
GRUPO
A
B
$\mathrm{C}$
$\mathrm{D}$

\section{COMPONENTES}

2 pespontadores e 3 auxiliares

3 pespontadores e 3 auxiliares

1 pespontador 2 auxiliares

2 pespontadores e 3 auxiliares

Estes grupos ficaram em processo de adaptação de trabalho por 2 meses, período no qual a empresa se comprometeu a pagar a média salarial dos últimos meses. No terceiro mês, a produção apresentada pelos grupos, com pagamento de salário conforme ítem 8.5 , apresentou o seguinte resultado:

Tabela 9.1- PRODUTIVIDADE GRUPO PILOTO DE PESPONTO - Jan 95

GRUPO PARES/DIA PER CAPITA ADICIONAL SALÁRIO (\%)

$\begin{array}{llll}\text { A } & 73 & 14,58 & 29 \\ & & & \\ \text { B } & 93 & 15,50 & 42 \\ \text { C } & 53 & 17,69 & 60 \\ \text { D } & 62 & 12,42 & 26 \\ \text { TOTAL } & 72,2 & 15,27 & 38\end{array}$

Os resultados apresentados foram bastante satisfatórios após 2 meses de treinamento e adequações. Durante este tempo os próprios funcionários foram redistribuindo as tarefas conforme achavam mais adequado. Foi dada ampla liberdade para a escolha de método de trabalho, sendo solicitado apenas o trabalho com poucas fichas no grupo, que seriam posteriormente monitoradas pelo sistema de gerenciamento visual da produção. A pressão pela produção decorre do próprio sistema pecista.

No final do terceiro mês, é expressivo o ganho de produtividade observado. Os funcionários assimilaram de forma rápida a delicada transformação do trabalho 
individual para o trabalho em grupo, com a remuneração salarial em função do resultado também do grupo.

Isto facilitou o processo de expandir rapidamente os grupos de trabalho prioritariamente para o setor de pesponto, antes que a preparação.

\section{3- A IMPLANTAÇÃO NO PESPONTO}

O pesponto A era a esteira de pesponto que trabalhava com os produtos mais complexos e diversos, e foi por esta linha que a diretoria da empresa decidiu implantar os grupos de trabalho.

Em março de 95 todo o efetivo do Pesponto A já estava configurado por grupos de trabalho, assim constituídos:

Tabela 9.2- GRUPOS DE TRABALHO NO PESPONTO "A"

$\begin{array}{ll}\text { PESSOAS } & \text { GRUPO TRABALHO } \\ 01 & \text { chefia } \\ 40 & 8 \text { grupos, com } 2 \text { pespontadores e } 3 \text { auxiliares } \\ 06 & 1 \text { grupo, com } 3 \text { pespontadores e } 3 \text { auxiliares } \\ 03 & 1 \text { grupo de apoio, com } 2 \text { pespontadores e } 1 \text { auxiliar } \\ 09 & \text { acabamento } \\ 03 & \text { pequenos reparos } \\ 02 & \text { dobrar vivo } \\ 02 & \text { afastamento }\end{array}$


Para efeito de acompanhamento de índices de produção, ficou-se com 9 grupos de trabalho, com 46 pessoas envolvidas nos grupos, pois no mês de março de 95 o grupo maior ( 3 pespontadores e 3 auxiliares ) trabalhou por hora.

Para medir a performance dos grupos, escolheu-se 2 medidas: A média de pares produzidas, que é um fator quantitativo, e também o ganho semanal ( \% ). do grupo, que mostra um comparativo de produtividade com o decorrer do tempo. Os resultados obtidos nos meses de março e abril foram:

Tabela 9.3- MÉDIA DE PARES PRODUZIDOS GRUPOS PESPONTO "A"

$$
\text { março } 95
$$

GRUPO $\quad 1^{\mathrm{a}} \operatorname{sem} .2^{\mathrm{a}}$ sem. $3^{\mathrm{a}}$ sem. $4^{\mathrm{a}}$ sem.

\begin{tabular}{|c|c|c|c|c|c|c|c|c|}
\hline A & 48 & 50 & 60 & 62 & & 62 & $72 *$ & 72 \\
\hline $\mathrm{D}$ & 62 & 65 & $59 *$ & 69 & & 63 & 73 & 66 \\
\hline $\mathrm{E}$ & 51 & 57 & $53 *$ & 58 & & 56 & 71 & 73 \\
\hline $\mathrm{G}$ & 48 & 45 & 68 & 59 & & 85 & $99 *$ & 125 \\
\hline $\mathrm{H}$ & \multicolumn{4}{|c|}{ trabalho por hora no mês } & & 29 & 147 & 126 \\
\hline $\mathrm{I}$ & 65 & 60 & 64 & 72 & & 73 & 77 & $63 *$ \\
\hline $\mathrm{J}$ & 76 & 74 & $72 *$ & 81 & & 88 & 100 & 111 \\
\hline L & 36 & 45 & 62 & 46 & & 58 & $53 *$ & 77 \\
\hline M & 65 & 65 & 73 & 71 & & 75 & $77 *$ & 80 \\
\hline soma total & 451 & 461 & 511 & 518 & & 688 & 769 & 793 \\
\hline$(\operatorname{sem} H)$ & & & & & & 559 & 622 & 667 \\
\hline média per capita. & 11 & 13 & 13 & & 15 & 17 & 17 & \\
\hline$(\operatorname{sem} H)$ & & & & & & 14 & 15 & 17 \\
\hline
\end{tabular}

abril 95

$1^{\mathrm{a}}$ sem. $2^{\mathrm{a}}$ sem. $3^{\mathrm{a}}$ sem.

2

25

Obs: 
Tabela 9.4- MÉDIA DE GANHO SEMANAL (\%) PESPONTO “A”

março 95

GRUPO $\quad 1^{\mathrm{a}} \mathrm{sem} .2^{\mathrm{a}} \mathrm{sem} .3^{\mathrm{a}} \mathrm{sem} .4^{\mathrm{a}} \mathrm{sem}$. abril 95

$1^{\mathrm{a}}$ sem. $2^{\mathrm{a}}$ sem. $3^{\mathrm{a}}$ sem. $4^{\mathrm{a}} \mathrm{sem}$.

\begin{tabular}{|c|c|c|c|c|c|c|c|c|}
\hline A & 38 & 42 & 48 & 52 & & 54 & 53 & 57 \\
\hline $\mathrm{D}$ & 60 & 60 & $54^{*}$ & 63 & & 57 & 65 & 59 \\
\hline $\mathrm{E}$ & 49 & 52 & $48^{*}$ & 52 & & 50 & 54 & 54 \\
\hline $\mathrm{G}$ & 41 & 39 & 55 & 46 & & 64 & $63^{*}$ & 68 \\
\hline $\mathrm{H}$ & \multicolumn{4}{|c|}{ trabalho por hora no mês } & $\ldots$ & 67 & 74 & 65 \\
\hline I & 54 & 52 & 55 & 58 & & 57 & 65 & $54^{*}$ \\
\hline $\mathrm{J}$ & 62 & 60 & $60^{*}$ & 67 & & 68 & 70 & 71 \\
\hline $\mathrm{L}$ & 31 & 37 & 41 & 38 & & 47 & $40^{*}$ & 53 \\
\hline$M$ & 54 & 50 & 52 & 54 & & 63 & $62 *$ & 61 \\
\hline
\end{tabular}

média sem H $49 \quad 49 \quad 53 \quad 54$

$58 \quad 59 \quad 60$

63

O processo de implantação dos grupos de trabalho no pesponto A passou por uma fase de queda significativa nas semanas iniciais, com recuperação gradual e constante. A produtividade dos grupos vem aumentando semana a semana, de forma ininterrupta. Com dois meses de implantação a curva de produtividade continuou crescente, sem patamares de estabilização.

A estrutura organizacional do chão de fábrica, com operários, chefias e gerência, compreendeu os beneficios dos grupos de trabalho. A adoção dos novos conceitos parece ter sido bem assimilada durante os dois meses de mudança. Resistências foram detectadas, como esperado em todo processo de mudança. A participação e o empenho dos níveis hierárquicos superiores foi fundamental para a implantação do projeto. Com índices de produção melhorando semana a semana a adesão foi também gradativamente aumentando. 
No início da transformação do pesponto A em grupos, era muito dificil notar grupos trabalhando em horário de almọ̧o, ou fora do horário de trabalho, situação comum no antigo sistema tarefeiro. Decorridos 2 meses, já percebe-se os grupos se mobilizando fora do horário de trabalho.

O envolvimento dos funcionários no processo é fundamental. Em todos os contatos de reuniões efetuadas, a transparência das informações e a rapidez do feed back são importantes. O papel da chefia imediata, depois de convencido dos beneficios do trabalho em célula, foi muito importante.

Praticamente toda a equipe de funcionários foi mantida, com uma ou outra rara exceção. Alguns grupos apresentaram produtividade melhor que outros, porém não foram necessárias mudanças substanciais no quadro de funcionários.

Apesar do aumento compensatório de $15 \%$ no preço da peça paga ao funcionário, as primeiras sinalizações indicam que o valor a ser gasto com a seção não terá o aumento correspondente, pois houve uma redução grande das horas paradas, que eram pagas aos funcionários quando não existia trabalho a ser realizado.

\section{4- IMPLANTAÇÃO DO GERENCIAMENTO VISUAL DA PRODUÇÃO}

$\Theta$ gerenciamento visual da produção começou a ser implantada durante o mês de abril, apenas monitorando o corte, a preparação e o pesponto.

Foram realizadas diversas reuniões de conscientização e treinamento com a gerência de produção e os encarregados dos setores, existindo uma assimilação boa dos novos procedimentos operacionais. 
No dia 03 de maio o inventário aferido nas seções apresentou o seguinte resultado:

Tabela 9.5- INVENTÁRIO NAS SEÇÕES PÓS GERENCIAMENTO VISUAL

\begin{tabular}{|c|c|c|}
\hline SEÇÃO & INVENTÁRIO( pares) & GIRO(dias ) \\
\hline CORTE & 1584 & $1584 / 2600=0,61$ \\
\hline PREPARAÇÃO & 1872 & $1872 / 1900=0,99$ \\
\hline \multirow{2}{*}{ PESPONTO } & 1776 & $1776 / 1620=1,10$ \\
\hline & & 2,70 dias \\
\hline
\end{tabular}

Com a implantação do gerenciamento visual, praticamente acabaram os altos estoques parados entre as seções. $O$ fato de tornar o que está oculto visível para todos é um poderoso instrumento de pressão social que acusa tanto os desbalanceamentos como o próprio relaxamento dos chefes de seção com relação aos estoques intermediários.

Com um mês de utilização, o giro geral das três seções caiu para 2,7 dias contra 6,7 dias verificado no primeiro levantamento. $O$ objetivo do projeto era atingir um giro de 2,1 dias.

Percebe-se uma grande redução de inventário no setor de corte, que é o responsável pela pressão de produção pela produção( a produção nascer bem no corte é importante para uma influência positiva para as demais seções).

O setor de preparação em abril ainda não estava configurado por grupo de trabalho, apesar de toda fundamentação teórica e arquitetura conceitual do novo layout da seção estar pronta. As operações verificadas na seção são muito mais simples 
que aquelas observadas no pesponto e no corte. Espera-se um giro menor que 0,5 dias, contra os 0,99 dias aferidos.

Apenas o pesponto " $A$ " estava configurado por grupos de trabalho, o que contribui para o giro ainda ser um pouco além do que o inicialmente planejado. Quando todo o pesponto estiver trabalhando em grupos de trabalho, o giro com certeza cairá ainda mais. Convém observar que o pesponto " $\mathrm{B}$ " trabalha com produtos de pedidos maiores e exportação, o que facilita o processo de produção em grupos com maior produtividade.

As metas de redução de giro traçadas no início do projeto começam a ser rapidamente atingidas, com todos os beneficios associados para a organização.

$\Theta$ acompanhamento mais direto precisou ser interrompido no mês de junho de 1995. Após este período, segundo-testemunhal e contatos telefônicos, toda a preparação como a linha de pesponto $B$ foi transformada em grupos de trabalho. $O$ sistema de gerenciamento visual foi implantado em sua forma original, e muito bem assimilado pelos funcionários de chão de fábrica.

Tanto os grupos de trabalho na produção como o gerenciamento visual continuam hoje, 1999, em plena utilização pela empresa, o que atesta o bom resultado do projeto idealizado e implantado há 4 anos atrás. 


\section{CAPÍTULO 10: CONCLUSÃO}

O surgimento do STP é fruto de um longo processo interno de aprendizado continuado, que tem desdobramentos até os dias atuais, isto é, a TMC é uma organização que está aprendendo a aprender, sempre buscando novas formas de configurar eficiência e eficácia em suas operações.

O sucesso da TMC pode ser menos creditados a atitudes isoladas de desenvolvimento de algumas técnicas articuladas como o JIT. Ainda que as inovações organizacionais sejam importantes, o suporte externo fornecido por organismos governamentais e não governamentais foram e são fundamentais para criar um arcabouço básico de desenvolvimento tecnológico e comercial, num projeto nacional articulado que envolva toda a comunidade científica e forças econômicas do país.

Recentemente a abertura de mercado de forma abrupta deixou a indústria nacional em uma situação de risco acentuado. O choque de competitividade tem levado os empresários nacionais a rápidas reorganizações, associações com outros grupos econômicos ou mesmo a venda de seus negócios. Esconder-se debaixo de uma manta protecionista tem sido o discurso do empresariado nacional.

$O$ fato é que, se o choque de competitividade foi um mal necessário, carecemos de um projeto amplo de desenvolvimento industrial. O país e seus agentes industriais continuam navegando sobre mares turbulentos sem instrumentos de correção de rota. Isto torna desigual o confronto de competitividade diante de uma concorrência transnacional globalizada. 
A defasagem concorrencial é verificada não apenas em máquinas e equipamentos, mas também em termos de organização do chão de fábrica. Medidas de racionalização algumas vezes não bastam para provocarem 0 diferencial competitivo, exigindo uma verdadeira mudança na cultura organizacional.

Avaliando a posteriori o estudo de casos apresentado, de forma pragmática foi uma experiência bem sucedida. A organização assimilou as alterações propostas nas medidas de racionalização. Houve um bom período de maturação para que as mudanças pudessem ser sentidas e gradativamente absorvida pela empresa. Diversas experiências pilotos foram efetuadas e serviram para criar um ambiente favorável de implantação mais ampla, ocorrido em sequencia.

A força de trabalho contribuiu de forma satisfatória, mesmo diante de transformações significativas de suas atividades, ou seja, mudança de um regime de trabalho individual e pagamento por operações substituido por um novo modelo de trabalho em grupo por pagamento por pares completos. A negociação de índices de pagamento melhores aos funcionários e o constante diálogo e transparência no processo de experiências e migração de sistema, contribuíram para a criação de um clima organizacional favorável às mudanças realizadas.

Da mesma forma, o gerenciamento visual da produção introduzido resultou em uma rápida assimilação. A natureza de trabalho dos encarregados das linhas de fabricação passou por alterações que reduziu o trabalho operacional de distribuição de tarefas. Consequências importantes do sistema de gereciamento desenvolvido foram a melhoria do fluxo de materiais e informações no chão de fábrica.

A mensuração do desempenho do novo sistema foram medidos basicamente pela redução de giro de materiais, consequentemente redução do lead time de produção e redução do capital de giro. Estas medidas de desempenho, na ocasião, foram aceitas pela diretoria da organização como significativas e suficientes para justificar um investimento inicial de racionalização. 
Apesar do bom termo da intervenção nesta tradicional empresa de calçados masculino de couro, faz-se necessário medidas mais setoriais que envolvam toda a cadeia produtiva do setor de calçados, que é um polo exportador brasileiro. Para um efeito mais longo e duradouro, não basta a adaptação de boas filosofias e técnicas de produtividade localizado em uma ou outra organização apenas. É preciso criar um efeito amplificador e multiplicador em diversas frentes.

Diante deste espectro, a universidade pode ter um papel mais relevante contribuindo também com capacitação dos recursos humanos e com o desenvolvimento de pesquisas e produção de trabalhos acadêmicos mais aplicados e setoriais, procurando reduzir um pouco os efeitos do choque de competitividade que tem atingido de forma necessária, mas impiedosa, as empresas nacionais. 


\section{BIBLIOGRAFIA}

AOKI, M. ( 1990 ). Toward an economic model of Japanese firm . Journal of Economic Literature. Depto of Economics, Stanford University. p . 1-27, mar.

BARÇANTE, L. C. ( 1998 ). Qualidade Total: Uma visão brasileira: O impacto estratégico na Universidade e na Empresa. Rio de Janeiro, Campus, p. 39.

BATEMAN, T. S. \& SNELL, S. A . ( 1998 ). Administração: construindo vantagem competititva. São Paulo, Atlas, p.95.

BURNS, T. \& STALKER, G. ( 1961). The management of inovation. Londres, Tavistock.

CAMPOS, V. F. ( 1992 ). TQC Controle da qualidade total ( no estilo japonês ). $4^{\circ}$ ed. Rio de Janeiro, Bloch.

CANÊDO, L.B. ( 1987 ). A.Evolução Industrial. São Paulo, Atual.

COLENCI, JR. A . ( 1992 ). Um estudo de sistematização da tecnologia de fixação por parafusos de alta resistência, no caso brasileiro. São Carlos. 450p. Tese (Doutorado) - Escola de Engenharia de São Carlos, Universidade de São Paulo.

COLENCI, JR. A . \& CIOSAKI, L. M. ( 1998 ). Gerenciamento visual da produção, implantação de células de fabricação e alterações na forma de remunerar a força de trabalho aplicados simultaneamente em uma industria de calçados. Niterói. Abstracts do ENEGEP 98.

COLENCF, JR. A. \& GUERRINI, F. M. ( 1999 ). Organizações voltadas para o aprendizado. São Carlos, 27p. Escola de Engenharia de São Carlos Universidade de São Paulo.

CORIAT, B. ( 1988 ). Automação programável: novas formas e conceitos da organização da produção. In SCHMITS, H., CARVALHO, R. Q. Automação, competitividade e trabalho: a experiência internacional. São Paulo, Hucitec.

CORRÊA, H. L. \& GIANESI, I.G. ( 1993). Just in time, MRP II e OPT. São Pauilo, Atlas. 
COVEY, S. R. . Os 7 hábitos das pessoas muito eficazes. $13^{\circ}$ ed.. São Paulo, Best seller, p. 313.

DANKBAAR, B. ( 1998 ). Autonomia no trabalho. Boletim fundação Vanzolini ano VI n ${ }^{\circ} 36$, p. 1. São Paulo, Depto de Engenharia de Produção - Escola Politécnica - USP.

EMERY, F. E. \& TRIST, E. L. ( 1972 ) . Characteristics of socio-tecnical systems. In: Davis, L. E., Taylor, J. C., (Eds) Design of jobs. Harmondsworth, Penguin .

ELLEGARD, K. , ENGSTROM, T., NLSSON, L. ( 1994 ). La réforme du travail industriel: principles et réalites de la planificacion de l'usine de montage d'automobiles Volvo a Uddevalla. Actes du Gerpisa, n.9, p.55-108. Paris; Gerpisa.

ESCRIVÃO FILHO, E. ( 1987 ). CCQ e just in time: uma análise integrada. São Paulo. 117p. Dissertação (Mèstrado) - PUC.

FLEURY, A . \& FLEURY, M. T. ( 1997 ). Aprendizagem e Inovação Organizacional. São Paulo, Atlas.

FOLHA DE SÃO PAULO, ( 1998 ). Se todos trabalhassem menos, haveria mais emprego?. São Paulo, 01 maio, especial : O colapso do trabalho, p. 5.

FUJMOTO, T. (1994). Reinterpreting the resource-capability view of the firm: a case of the development-production system of the Japonese auto makers. Tokio: Reserch Institute for the Japanese Economy ( mimeo ).

GIBSON, R. et al. ( 1998 ). Repensando o futuro. São Paulo, Makron.

GOLDRAT, E. M. \& COX J. ( 1986 ). A meta. 2 ed. São Paulo, IMAM.

GOLDRAT, E. M. \& FOX, R. E. ( 1989 ). A corrida pela vantagem competitiva. São Paulo, IMAM, p. 26.

HERBST, P. G. ( 1974). Autonomous groups functioning: exploration in behavior and theory measurement. London, Tavistock . p. 58.

HERZBERG, F., MAUSNER, B., SNYDERMAN, B. ( 1959 ). The motivation to work. New York, John Wiley.

IMAI, M. ( 1990 ). Kaizen. São Paulo, IMAM. 
JAPAN HUMAN RELATIONS ASSOCIATION ( 1997 ). O livro das idéias. $O$ moderno sistema japonês de melhorias e o emolvimento total dos funcionários. Porto Alegre, Bookman.

JONES, D., WORMACK, J., ROOS, D. ( 1990). A máquina que mudou o mundo: A história da produção enxuta. Rio de Janeiro, Campus.

JONSON, L. ( 1998 ). A experiência sueca. Boletim fundação Vanzolini ano VI $n^{\circ} 36$, p. 9. São Paulo, Depto de Engenharia de Produção - Escola Politécnica USP.

LUBBEN, R. T. ( 1989 ). Just in time. Uma estratégia avançada de produção. São Paulo, McGraw-Hill.

MARTINS, P. G.; LAUGENI, F.P. ( 1998 ). Administração da Produção. São Paulo, Saraiva. p.2.

MAX, R. ( 1998 ). Trabalho em grupos e autonomia como instrumentos da competição. São Paulo, Atlas. Atlas.

MAXIMIANO, A. C. A. ( 1995 ). Introdução à Administração. São Paulo,

MICHALET, C. A. ( 1984 ). O capitalismo mundial. Rio de Janeiro, Paz e Terra. p. 22.

MICKLETHWAIT, J. \& WOOLDRIDGE, A ( 1998 ). Os bruxos da Administração. Como entender a Babel dos gurus empresariais. Rio de Janeiro, Campus, p. 206-224.

MONDEN, Y. ( 1984 ). Sistema Toyota de Produção. São Paulo, IMAM.

MONKS, J. G. ( 1987). Administração da produção. São Paulo, McGrawHill, p. 4.

NIPPON STEEL CORPORATION ( 1984 ). Japão: Terra e povo. p. 31. São Paulo.

OHNO, T. ( 1997 ). O sistema Toyota de Produçâo. Porto Alegre, Bookman.

OLIVEIRA, D. P. R. ( 1988 ). Sistemas, Organização e Métodos. Uma abordagem gerencial. $2^{\circ}$ ed. São Paulo, Atlas, p. 44 . 

$9-17$.

PLOSSL, G. W. ( 1993 ). Administração da produção. São Paulo, Makron, p.

RESENDE, M. O. ( 1989 ) Plamejamento e controle da produção: Teoria e prática da indústria mecânica no Brasil. São Carlos, Tese ( Doutorado ) - Escola de Engenharia de São Carlos, Universidade de São Paulo.

ROCHA, D. ( 1995 ). Fundamentos técnicos da produção. São Paulo, Makron, p. 5.

SACOMANO, J. B. ( 1990 ). Uma análise da estrutura funcional do planejamento e controle da prodıção e suas técnicas auxiliares. São Carlos. 378p. Tese (Doutorado) - Escola de Engenharia de São Carlos, Universidade de São Paulo.

SALERNO, M. S. ( 1985 ). Produção, trabalho e participação. CCQ e Kamban numa nova imigração japonesa. Rio de Janeiro. 99p. Dissertação (Mestrado) - Universidade Federal do Rio de Janeiro.

SATOSHI, K. ( 1985 ). Japão, a outra face do milagre. São Paulo; Brasiliense. p. 13-29.

SILVA, E. S. ( 1994 ). Kanban em célula piloto como técnica auxiliar do planejamento e controle da produção. São Carlos. 124 p. Dissertação ( Mestrado )Escola de Engenharia de São Carlos - Universidade de São Paulo.

SCHOMBERGER, R. J. ( 1987 ) Técnicas industriais japonesas: nove lições ocultas sobre a simplicidade. $2^{\circ}$ ed. São Paulo, Pioneira. Pioneira.

SCHONBERGER, R. J. ( 1988 ). Fabricação classe universal: São Paulo,

SHINGO, S. ( 1996a ). Sistema de produção com estoque zero: O sistema Shingo para melhorias contímuas. Porto Alegre, Bookman.

SHINGO, S. ( 1996b). O sistema Toyota de Produção do ponto de vista da engenharia de produção. Porto Alegre, Bookman.

SHIMOKAWA, K. ( 1993 ). The auto industry enters an era of restructuring and globalization. Journal of Japanese Trade and Industry, n.4, p. 9-11.

STERRS, R., SHIN, Y., UNGSON, G. ( 1989 ). The Chaebol. New York, Harper and Row

TRAGTENBERG, M. ( 1989 ). Administração, poder e ideologia. São Paulo, Cortez Editora. 
UNESCO ( 1991 ). Anuário estatístico.

WREN, D. ( 1994 ). The Evolution of Management Thought. New York, John Wiley. \& Sons.

YOSHIMOTO, T. ( 1992 ). Qualidade, Produtividade e Cultura. São Paulo, Saraiva. p. 23. 